\title{
Slaapklachten in de periode voorafgaande aan het hartinfarct
}

Citation for published version (APA):

Nelissen-de Vos, Y. C. M. (1994). Slaapklachten in de periode voorafgaande aan het hartinfarct. [Doctoral Thesis, Maastricht University]. Datawyse / Universitaire Pers Maastricht. https://doi.org/10.26481/dis.19940623yn

Document status and date:

Published: 01/01/1994

DOI:

10.26481/dis.19940623yn

Document Version:

Publisher's PDF, also known as Version of record

\section{Please check the document version of this publication:}

- A submitted manuscript is the version of the article upon submission and before peer-review. There can be important differences between the submitted version and the official published version of record.

People interested in the research are advised to contact the author for the final version of the publication, or visit the DOI to the publisher's website.

- The final author version and the galley proof are versions of the publication after peer review.

- The final published version features the final layout of the paper including the volume, issue and page numbers.

Link to publication

\footnotetext{
General rights rights.

- You may freely distribute the URL identifying the publication in the public portal. please follow below link for the End User Agreement:

www.umlib.nl/taverne-license

Take down policy

If you believe that this document breaches copyright please contact us at:

repository@maastrichtuniversity.nl

providing details and we will investigate your claim.
}

Copyright and moral rights for the publications made accessible in the public portal are retained by the authors and/or other copyright owners and it is a condition of accessing publications that users recognise and abide by the legal requirements associated with these

- Users may download and print one copy of any publication from the public portal for the purpose of private study or research.

- You may not further distribute the material or use it for any profit-making activity or commercial gain

If the publication is distributed under the terms of Article $25 \mathrm{fa}$ of the Dutch Copyright Act, indicated by the "Taverne" license above, 


\section{SLAAPKLACHTEN IN \\ DE PERIODE VOORAFGAANDE AAN HET HARTINFARCT}


Lay-out:

Isel van Noppen

Druk:

Datawyse / Universitaire Pers Maastricht

CIP-GEGEVENS KONINKLIJKE BIBLIOTHEEK, DEN HAAG

Nelissen-de Vos, Yolande

Slaapklachten in de periode voorafgaande aan het hartinfaret / Yolande Nelissen-de Vos, - Maastricht : Universitaire Pers Maastricht

Proefschrift Maastricht. - Met lit. opgv. - Met

samenvatting in het Engels.

ISBN $90-5278-142-7$

Trefw.: slaapstoornissen / hartinfarcten. 


\section{SLAAPKLACHTEN IN \\ DE PERIODE VOORAFGAANDE AAN HET HARTINFARCT}

\section{PROEFSCHRIFT}

ter verkrijging van de graad van doctor aan de Rijksuniversiteit Limburg te Maastricht, op gezag van de Rector Magnificus, Prof.Dr. H. Philipsen, volgens het besluit van het College van Dekanen, in het openbaar te verdedigen op donderdag 23 juni 1994 om 16.00 uur

door

Yolande Catharina Magdalena Nelissen-de Vos

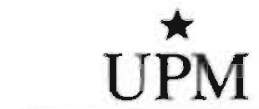




\section{Promotor:}

Prof.Dr. A.P.W.M. Appels

Co-promotor:

Dr. P.R.J. Falger

\section{Beoordelingscommissie:}

Prof.Dr. F. Sturmans (voorzitter)

Dr. F, Bär

Prof.Dr. J. Jolles

Prof.Dr. S. Maes (Rijksuniversiteit Leiden)

Dr. H.L.G.J. Merckelbach

Het verschijnen van dit proefschrift werd mede mogelijk gemaakt door de steun van de Nederlandse Hartstichting. 


\section{INHOUDSOPGAVE}

Hoofdstuk 1. Theoretische achtergronden

1.1. Inleiding

1.2. Verschijnselen van vitale uitputting als risicoindicator voor het hartinfarct

1.3. Slaapklachten voorafgaande aan het hartinfarct

$\mathrm{Blz}$.

1.4. "Need for Control"

1.5. Samenvatting

Hoofdstuk 2. Onderzoek naar slaapklachten: een literatuuroverzicht is

2.1. Inleiding

2.2. De classificatie van slaapklachten

2.3. Het voorkomen van slaapklachiten in de algemene bevolking

2.4. Insomnia en hypersomnia

2.5. Oorzakelijke factoren van slaapklachten 23

2.6. Meetproblemen 25

2.7. Slaapapneu 29

2.8. Samenvatting 30

Hoofdstuk 3. Hypothesen, exploraties en methoden 31

3.1. Vraagstelling \& hypothesen 31

3.2. Methode: "case-control" onderzoek 32

3.3. Validiteitsproblemen $\quad 35$

3.4. Definities en selectie van "cases" en controles 37

3.5. Procedures 38

3.6. De meetinstrumenten $\quad 40$

3.7. Statistische analyses 46

Hoofdstuk 4. Vitale uitputting, "Need for Control, en andere risicofactoren en hun samenhang met het hartinfarct $\quad 49$

4.1. Distributie van de mogelijke "confounders" 49

4.2. Vitale uitputting als risicoindicator van het hartinfarct $\quad 52$

4.3. "Need for Control" als risicoindicator voor het hartinfarct: De Marburgse vragenlijst 
Hoofdstuk 5 Slaapklachten en hun samenhang met het hartinfarct 63

5.1. Inleiding

5.2. Het verband tussen slaapklachten en "confounders"

5.4. De slaapklachtenlijst van Jenkins et al.

5.5. De Slaap-Waak Ervaring Lijst

5.6. "Insomnia" en "Hypersomnia"

5.7. Lichamelijke en geestelijke oorzakelijke factoren

5.8. Slaapapneu

5.9. Samenvatting

6.1. Behoort een gestoorde slaap tot de voorlopers van het hartinfarct?

6.2. Vitale uitputting als voorloper van het hartinfarct

6.3. "Need for control" als voorloper van het hartinfarct

6.4. Algehele samenvatting en aanbevelingen voor toekomstig onderzoek

Summary

Literatuur

Bijlagen

Dankwoord 


\section{HOOFDSTUK 1}

\section{THEORETISCHE ACHTERGRONDEN}

\subsection{INLEIDING}

In de afgelopen decennia is er veel onderzoek gedaan naar de relatie tussen psychologische factoren en het hartinfarct, waarbij de meeste aandacht is uitgegaan naar een specifieke gedragsstructuur, het Type A gedrag (Friedman \& Rosenman, 1959; Rosenman \& Friedman, 1961; Rosenman et al., 1964; Jenkins, 1971; Rosenman et al., 1975; Brand et al., 1976; Jenkins, 1976; Rosenman et al., 1976; Orth-Gomer et al., 1980; Verhagen et al., 1980; Appels, 1983; Appels, 1985; Matthews \& Haynes, 1986; Haynes \& Matthews, 1988). De laatste jaren is met name in het Amerikaanse onderzoek de aandacht voor het globale Type A gedrag verschoven in de richting van een van de elementen hiervan, namelijk "hostility" (vijandigheid) (Matthews \& Haynes, 1986; Williams, 1987; Haynes \& Matthews, 1988).

In Nederland heeft het onderzoek naar psychologische determinanten van het hartinfarct zich in de afgelopen tien jaar behalve op Type A gedrag voornamelijk gericht op de mentale toestand voor het infarct. Uit ouder onderzoek is bekend dat de toekomstige hartinfarctpatiënt niet alleen vaak klaagt over pijn op de borst, maar ook over vermoeidheid, lusteloosheid, en een slechte slaap (Thiel et al, 1973; Friedman et al., 1974; Alonzo et al., 1975; Klatsky et al., 1976; Nixon, 1976; Kuller, 1978; Crisp et al., 1984). Onbekend is om welke klachten het hier nu precies gaat en of zij geen neveneffecten vormen van een reeds aanwezig hartlijden of van somatische risicofactoren. In prospectief onderzoek is aangetoond dat deze gevoelens van "vitale uitputting" tot de voorlopers van het infarct behoren (Appels \& Mulder, 1988). "Case-control" onderzoek kwam tot dezelfde bevinding (Verhagen et al., 1980; Falger, 1989).

In het onderhavige onderzoek ligt de nadruk vooral bij de slaapklachten als onderdeel van vitale uitputting. Het is niet geheel duidelijk welke specifieke slaapklachten het risico op een hartinfarct vergroten (Thiel et al , 1973; Floderus, 1974; Friedman et al., 1974; Partinen et al., 1982; Jenkins, 1983; Thomas et al., 1973; Siegrist et al., 1986). Het onderzoek tracht hier inzicht in te verkrijgen. 
De redenen voor het ontstaan van vitale uitputting zijn nog niet volledig bekend, maar kunnen mogelijk op de volgende wijze worden verklaard. De toekomstige hartinfarctpatiënt, voornamelijk te karakteriseren als iemand die doorgaans Type A gedrag vertoont, tracht zoveel mogelijk controle uit te oefenen over allerlei gebeurtenissen in de directe omgeving ("Need for Control"). Na een lange strijd zou de periode voor het infarct worden gekenmerkt door controleverlies; de infarctpatiënt geeft het gevecht uiteindelijk volledig op ("Immersion") (Siegrist et al., 1982, 1984; Matschinger et al., 1986; Siegrist, 1987). Dit gevecht om controle en tenslotte het opgeven daarvan, kan zich uiten in depressieve gevoelens en in uitputting. In prospectief onderzoek is aangetoond dat toekomstige hartinfarctpatiënten hoger scoren t.a.v. "immersion" dan anderen (Matschinger et al., 1986; Siegrist, 1987). In ditzelfde onderzoek werd tevens gevonden dat slaapklachten, met name doorslaapproblemen, vaker door hartpatiënten werden gerapporteerd. Ook werd een relatie tussen een hoge "immersion"-score en slaapklachten gevonden (Siegrist et al., 1986). Gegeven deze interessante samenhang, richt het onderhavige onderzoek zich tevens op "need for control". Hierdoor is het mogelijk om de beide concepten vitale uitputting en "need for control", zij het summier, in één studie te onderzoeken.

In aansluiting op deze inleidende paragraaf, waarin werd ingegaan op een aantal psychologische factoren die verband houden met het hartinfarct, zullen in de hierna volgende paragrafen deze drie persoonlijkheidskenmerken: vermoeidheid voor het hartinfarct, slaapklachten en "need for control" afzonderlijk worden besproken.

\subsection{VERSCHIJNSELEN VAN VITALE UITPUTTING ALS RISICOINDICATOR VOOR HET HARTINFARCT}

\section{A. Vroege studies}

Het onderzoek naar vitale uitputting als prodromale factor van het hartinfarct kan worden beschouwd als een voortzetting van het oudere onderzoek over depressie als mogelijke risicofactor van het hartinfarct en de plotselinge dood. Bruhn (1966) rapporteerde dat in vergelijking met een gezonde controlegroep hartinfarctpatiënten hoger scoorden op de MMPI-depressieschaal, terwijl Paffenbarger et al. (1966) vonden dat psychologische uitputting significant samenhing met sterfte als gevolg van coronaire hartziekte. Lebovitz (1967), Thomas et al. (1973) en Wolf (1967) hebben eveneens onderzoek verricht naar depressie als prodromale factor. Lebovitz (1967) vond evenals Paffenbarger et al. (1966) een samenhang tussen een fatale hartaanval en een verhoogde MMPI-depressiescore. Een prospectief onderzoek bij medische studenten toonde aan dat een verhoogde score op een bepaalde 
depressielijst het voorkomen van een hartinfaret 20 jaar later voorspelde (Thomas et al., 1973). In deze depressielijst werd o.a. gevraagd naar uitputting of vermoeidheid; depressieve gevoelens; toename van slaapbehoefte; en piekeren over de lichamelijke gezondheid. Toekomstige hartpatiënten klaagden vooral over vermoeid wakker worden.

Met name de ideeën van Engel (1968) en Wolf (1967) zijn een leidraad geweest voor de studie van vitale uitputting, voor het eerst toegepast in het IMIRonderzoek (zie B.). In tegenstelling tot de opvattingen van Paffenbarger, Lebovitz, en anderen die er allen van uitgaan dat hartinfarctpatiënten van nature personen met een latente depressie zijn, geven Engel en Wolf er de voorkeur aan de depressieve gevoelens bij hartinfarctpatiënten te beschouwen als prodromale neveneffecten van een algemene verzwakking of malaise. Engel gaat uit van het "giving-up given-up" complex, waarin adequate "coping"-mechanismen ontbreken, waardoor het onmogelijk is geworden om constructief om te gaan met veranderingen in de omgeving. Psychologische en sociale strategieẽn die in het verleden bruikbaar bleken, zijn niet langer effectief. Eenmaal in een impasse geraakt, treden er veranderingen op in de manier waarop men zichzelf en de omgeving waarneemt.

Engel geeft vijf karakteristieke kenmerken van het "giving-up - given-up complex" aan. Het eerste kenmerk wordt gevormd door het zich openbaren van gevoelens van hulpeloosheid en/of hopeloosheid. Bij hulpeloosheid heeft men het gevoel dat hulp van buitenaf mogelijk is (niet dat deze zal komen, maar nog kan komen). Bij hopeloosheid verwacht men dat ook hulp vanuit de omgeving niet in staat is om de negatieve gevoelens op te lossen. Het tweede kenmerk is een negatief zelfbeeld en als derde een verlies van bevrediging door sociale relaties en levensrollen. Een vierde karakteristiek is het optreden van een verbreking in de continuïteit tussen verleden, heden en toekomst. Tenslotte komen er herinneringen aan vroegere "giving-up" ervaringen naar boven. Volgens Engel openbaren zich ziekten wanneer men niet uit deze impasse kan geraken. Daarbij geldt wel als voorwaarde dat er sprake is van een predispositie voor deze ziekte.

Wolf (1967) beschrijft de periode voorafgaande aan het hartinfarct beeldend als "the end of the rope". Als gevolg van het feit dat er veeleisende conflicten zijn geweest, is men in een toestand van "emotional drain" geraakt: de oplossing van de problemen komt niet meer in zicht, en met het opgeven glipt het touw uit handen. Het hartinfarct is in deze visie de oplossing voor een probleem waar men niet uit kon komen.

Cardiologen en epidemiologen die onderzoek deden naar prodromale verschijnselen van het hartinfaret en de plotselinge dood constateerden dat 30-50\% van alle infarctpatiënten klaagden over vermoeidheid, algemene malaise en/of gebrek aan energie in de periode yoorafgaande aan het fatale infarct (Stowers, 1970; Kuller et al., 1972; Kinlen, 1973; Alonzo et al., 1975; Fraser, 1978; Kuller, 1978; 
Rissanen et al., 1978). In tegenstelling tot wat men vermoedde, werden bij pathologisch-anatomisch onderzoek van slachtoffers van een plotselinge dood geen veranderingen in het hart gevonden die duidelijk in relatie stonden met deze prodromale symptomen (Kuller et al., 1972, 1978; Rissanen et al., 1978). Deze gevoelens kwamen ook voor bij hen, die voor hun infaret geen last van angina pectoris (AP) hadden. Het bleek dus niet mogelijk deze verandering in de mentale toestand volledig toe te schrijven aan een klinisch of subklinisch hartlijden. Dit maakte verder onderzoek wenselijk naar de aard van deze toestand.

\section{B. Studies over vitale uitputting m.b.v. de Maastrichtse Vragenlijst}

De eerste stap in deze richting werd gezet in de "Imminent Myocardial Infarction Rotterdam" (IMIR)-studie. Uit dit onderzoek bleek dat toekornstige infarctpatiënten op een groot aantal vragen verschilden van een gezonde controlegroep. Deze vragen hadden beirekking op lusteloosheid, vermoeidheid, slechte slaap, depressie en doodswensen, verlies van vitaliteit, en projectie van onmachtsgevoelens op de buitenwereld. Deze 37 vragen werden gebundeld in een vragenlijst. Zij maken tesamen vorm A van de Maastrichtse Vragenlijst (MV) uit (Appels, 1980).

In 1979 werd een tweede prospectief onderzoek begonnen naar vitale uitputting als mogelijke risicofactor voor het hartinfarct, dat een nadere uitwerking van de resultaten van de IMIR-studie inhield. Deze "Rotterdam Civil Servants Study" (RCSS) vond plaats in Rotterdam bij in totaal 3.877 mannelijke gemeenteambtenaren. Allen verleenden op vrijwillige basis hun medewerking aan een uitgebreid gezondheidsonderzoek, dat plaatsvond in de periode januari 1978 - december 1980 . De deelnemers waren verdeeld over twee leeftijdsgroepen: 39-45 jaar en 54-65 jaar. Vitale uitputting werd gemeten op basis van de oorspronkelijke MV, welke voor de RCSS werd uitgebreid met 21 vragen, die op grond van klinische interviews waren geformuleerd. Alle deelnemers werden vervolgens over een gemiddelde periode van 4.2 jaar gevolgd. Gedurende deze periode kregen 59 mannen, die bij de aanvang van het onderzoek geen oud of bestaand hartlijden hadden, een al dan niet fataal infarct. Een score boven de mediaan van vorm A van de MV bleek het risico op een infarct significant te verhogen, onafhankelijk van het niveau van aanwezige somatische risicofactoren. Bij een analyse van deze samenhang per "follow-up" jaar bleek dat er een scherpe daling van het relatieve risico optrad. Tijdens het eerste jaar deed er zich geen enkel infarct voor bij hen, die beneden de mediaan van de MV scoorden. Het relatieve risico, gecorrigeerd voor leeftijd, bedroeg over het eerste jaar 10.05, terwijl dit voor het tweede, derde en vierde jaar respectievelijk $2.23,3.04$, en 0.68 was. Deze resultaten laten zien dat uitputting vooral een risicoindicator is voor een hartinfarct dat op korte termijn zal optreden.

In deze studie bleek dat 24 van de 58 vragen een voorspellend vermogen hadden (Appels et al., 1989). Daarvan behoorden er 16 tot de oorspronkelijke 37 
vragen uit het IMIR-onderzoek en acht tot de 21 nieuwe items. Na itemanalyse werden drie vragen alsnog verwijderd. De eindversie van de MV - vorm B - bestaat daarmee dus uit 21 vragen (Appels et al., 1988). Deze versie van de MV heeft een hoge interne consistentie (Cronbach's alpha $=0.89$ ), terwijl de correlatie met vorm A 0.92 bedraagt (Appels et al., 1987(a); 1988). Een verhoogde score op de MV betekent dus een verhoogd risico m.b.t. het krijgen van een hartinfarct.

De bevindingen van de prospectieve RCSS zijn door Verhagen et al. (1980) en Falger (1989) gerepliceerd in "case-control" onderzoek. Verhagen et al. vergeleken de score op de MV van 58 mannen met een eerste hartinfarct met die van 58 "gezonde" mannen. De hartinfarctpatiënten scoorden significant hoger op de MV dan de "gezonde" mannen. Beide groepen waren aan elkaar gelijk qua leeftijd en socio-economische status. Falger vergeleek 133 mannen, die opgenomen waren vanwege een eerste infarct, met 192 ziekenhuiscontroles en 133 "gezonde" buuricontroles. In deze studie werd vorm B van de MV gebruikt. "Cases" en controles werden in drie groepen verdeeld overeenkomstig ieders score in het eerste, tweede of derde tertiel van de MV. Na controle op AP bedroeg het relatieve risico samenhangend met een score in het tweede en derde tertiel 3.32 en 9.41 in de vergelijking tussen infarctpatiënten en buurtcontroles. In de vergelijking tussen infarctpatiënten en ziekenhuiscontroles bedroegen deze schattingen respectievelijk 2.33 en 4.29. Daarmee werd een onafhankelijke bevestiging gegeven van de uitkomsten van het prospectieve onderzoek.

\section{Nadere begripsbepaling}

Wat meet de MV nu eigenlijk? Appels geeft enkele mogelijke verklaringen. Als eerste zou de MV het laatste stadium - de uitputtingsfase - van Selye's "General Adaptation System" kunnen meten. Als tweede zou de vragenlijst het hierboven beschreven "giving up - given up" syndroom Engel (1968) kunnen beschrijven. In tegenstelling echter tot de aanvankelijke verwachtingen bleken in de RCSS de meeste items die depressie meten geen voorspellende waarde te bezitten. Vandaar dat er niet meer gesproken wordt over "vitale uitputting en depressie", zoals dat aan het begin van het onderzoek met de MV nog wel gebeurde (Appels, 1978; 1980).

Er is sprake van vitale uitputting wanneer iemand niet alleen klaagt over ongewone vermoeidheid en verlies aan energie, maar ook het gevoel heeft vers!agen te zijn. Vermoeid wakker worden is eveneens een belangrijk kenmerk. Bij vitale uitputting komt voorts vaak een toename in prikkelbaarheid en opvliegendheid voor, maar ook libidoverlies. Depressieve symptomen kunnen samenhangen met vitale uitputting, maar dit is niet noodzakelijk. Een belangrijk kenmerk is, tenslotte, dat het gevoel van eigenwaarde niet is aangetast en schuldgevoelens afwezig zijn (Appels et al., 1987(a)). 
In de RCSS werd ook nagegaan of deze toestand van vitale uitputting specifiek is voor hartpatiënten in de periode voorafgaande aan hun infarct. Daartoe werden de $\mathrm{MV}$-scores van toekomstige kankerpatiënten vergeleken met die van "gezonde" controles, die even oud waren en er vergelijkbare leefgewoonten op na hielden. Er werd echter geen verschil in gemiddelde MV-scores gevonden, hetgeen ook gold voor een vergelijking van deze kankerpatiënten met patiënten die later een maagzweer kregen (Appels et al., 1989). Gezien het feit dat deze resultaten zijn verkregen in prospectief onderzoek, kan men redelijkerwijs uitsluiten dat AP of een oud infarct, dan wel de klassieke risicofactoren (bloeddruk, cholesterol, roken, en diabetes), de samenhang tussen vitale uitputting en het hartinfarct kan verklaren.

\section{Samenvatting}

Zowel retrospectief als prospectief onderzoek heeft aangetoond dat een relatief hoge score op de MV het risico op het krijgen van een hartinfarct verhoogt. Uit prospectief onderzoek blijkt dat het hierbij gaat om een risicoindicator op korte termijn. Met de MV is het goed mogelijk gevoelens van vitale uitputting te meten. De aanwezigheid hiervan in de periode voorafgaande aan het hartinfarct heeft men tot nu toe niet kunnen verklaren d.m.v. lichamelijke factoren.

\subsection{SLAAPKLACHTEN VOORAFGAANDE AAN HET HARTINFARCT}

\section{A. Slaapklachten als prodromale factoren}

Traditionele symptomen als AP en ECG-veranderingen kunnen niet in voldoende mate uitsluitsel geven over de kans op het krijgen van een hartinfarct op korte termijn (Klatsky, 1976; Nixon, 1976). Daarom is ook onderzocht of gedragsveranderingen een prodromale betekenis hebben. In een studie van Nixon (1974) klaagde $80 \%$ van de 40 onderzochte hartinfarctpatiënten over ouder worden, $77 \%$ over ver̃moeidheid, $72 \%$ over extreme slaapbehoefte, $67 \%$ over prikkelbaarheid en afname van vrije tijdsactiviteiten, en $52 \%$ over AP. Ook Gillum (1976) toonde aan dat vermoeidheidsklachten en een toename van de slaapbehoefte kenmerkend zijn voor de periode vór het hartinfarct. Hierbij gaat het vaak om chronische klachten. De patiënten gaan in deze periode langer slapen of vallen op de meest ongewone tijdstippen in slaap. Een derde studie liet zien dat, vergeleken met controles, symptomen van vermoeidheid, alsmede langer slapen, twee tot drie maal vaker werden gerapporteerd door de echtgenotes van hartinfarctpatiënten, zowel overlevenden als gestorvenen (Kuller, 1978). Van de overlevenden klaagden 55\% over slaapklachten en $46 \%$ over vermoeidheid. De partners van gestorven patiënten 
gaven aan dat hun echtgenoten in $45 \%$ van de gevallen hadden geklaagd over extreme vermoeidheid en in $44 \%$ over slaapklachten. Een fysiologische oorzaak voor deze prodromen werd niet gevonden. Een mogelijke verklaring voor de vermoeidheid zou kunnen zijn dat deze een gevolg is van een onderliggende depressie (Kuller, 1978). Kavanagh et al. (1973) vermeldden dat hartinfarctpatiënten naast het hebben van vermoeidheidsklachten, welke het gevolg waren van zakelijke en sociale problemen, tevens klaagden over slaapproblemen in de periode voorafgaande aan het infarct. In de week voor het infarct sliepen deze patiënten gemiddeld slechts drie uur. In Nederland werd, tenslotte, in de RCSS gevonden dat toekomstige hartinfarctpatiênten in de periode voor het infarct problemen hadden met inslapen en tevens 's morgens bij het opstaan al moe waren (Appels et al., 1987(b)). Nadere analyse leerde dat vooral de klacht moe wakker worden geassocieerd was met toekomstig hartlijden (Appels, 1990).

In deze studies werd, samenvattend, als belangrijkste klacht aangegeven dat hartpatiënten voorafgaande aan het infarct erg moe zijn; voorts wordt deze periode gekenmerkt door een overmatige slaapbehoefte of door inadequate en gestoorde slaap.

\section{B. Slaapklachten als risicoindicator}

Het onderzoek naar slaapklachten als mogelijke risicoindicator in de periode voorafgaande aan het hartinfarct kenmerkt zich tot nu toe door een weinig specifieke aanpak. Zowel dwarsdoorsnede-, "case-control-", als longitudinale studies zijn uitgevoerd om het vórkomen van deze risicoindicator aan te tonen.

\section{B.1. Dwarsdoorsnede-onderzoek}

Aan 5119 Finse mannen werd gevraagd hoeveel uur meñ gemiddeld sliep, teneinde na te gaan of er een relatie bestond tussen slaapduur en hartziekte (Partinen et al., 1982). Zij vonden dat degenen die aangaven langer dan 9 uur te slapen een hoger risico op een hartinfarct, terwijl degenen die korter sliepen dan 6 uur een grotere kans hadden op "symptomatic coronary heart disease" (d.w.z. AP). Deze relaties bleven ook bestaan na controle op leeftijd, slaapkwaliteit, gebruik van slaap- en kalmeringsmiddellen, roken, alcoholgebruik, Type A-gedrag, neuroticisme, en medicijnengebruik t.b.v. hartaandoeningen of hoge bloeddruk. Dit korter slapen zou voornamelijk gepaard gaan met slechte slaapkwaliteit, AP en pijnklachten die daarmee samenhangen, hogere leeftijd, en Type A gedrag, langer slapen ging echter gepaard met goede slaapkwaliteit en een hoog risico op een infarct. Een soortgelijk onderzoek van Wingard et al. (1983) komt tot overeenkomstige resultaten. 


\section{B.2. Retrospectief onderzoek}

Thiel et al. (1973) onderzochten middels een vragenlijst hoe hartinfarctpatiënten $(\mathrm{N}=50)$ en gezonde personen $(\mathrm{N}=50)$ tussen de 40 en 60 jaar zich de afgelopen maanden hadden gevoeld. In deze vragenlijst kwamen onder meer ter sprake: problemen m.b.t. huwelijk, werk en beroep, eetgewoonten, zenuwachtigheid, angst, depressie en slaap. Over dit laatste werd gevraagd hoe men in de afgelopen 12-24 maanden had geslapen. De slaap van de patiënten in de periode voorafgaande aan het infarct was significant slechter dan bij de gezonde personen. Vaak ging het hierbij om chronische klachten; sommigen hadden al 5 tot 10 jaar slaapproblemen. Er werd tevens gevraagd of men zich depressief had gevoeld, waaronder werd verstaan het voorkomen van vermoeidheidsklachten overdag, problemen met slapen 's nachts en 's morgens moe wakker worden. Van de hartinfarctpatiënten gaf $80 \%$ aan deze klachten te hebben gehad in de periode voorafgaande aan het infarct.

Siegrist $(1985,1986)$ onderzocht bij 44 patiënten of er bepaalde slaapklachten voorkwamen in de periode voorafgaande aan het hartinfarct, en waar deze mee samenhingen. Eenderde gaf aan slaapklachten te hebben gehad in de weken voor het infarct. Deze klachten werden voor $50 \%$ verklaard door ernstige sociale en emotionele problemen, voor $25 \%$ door AP, en voor $25 \%$ door lichamelijke klachten.

Falger et al. (1988) vergeleek 133 hartinfarctpatiënten met zowel 192 "zieke." als 133 "gezonde" controles en vond dat hartinfarctpatiënten vaker aangaven moeite met inslapen te hebben, vermoeid wakker te worden, en overdag een dutje doen dan de beide controlegroepen.

Tot nu toe werden alle besproken onderzoeken bij mannen verricht. Bengtsson (1972) onderzocht het voorkomen van psychosociale factoren voor het ontstaan van een hartinfarct, waaronder slaapklachten, ook bij vrouwen. Daarbij werden gezonde vrouwen $(\mathrm{N}=578)$ vergeleken met vrouwen met $A P(N=29)$, patiënten met ECG-afwijkingen ( $N=23)$, en hartinfarctpatiënten $(N=47)$. De laatsten rapporteerden niet alleen méér risicofactoren (o.a. hypertensie, te hoog serumcholesterol- en triglyceridengehalte, roken, en overgewicht) alsmede meer angst en zenuwachtigheid dan de anderen, maar ook hadden zij meer last gehad van slapeloosheid in de 12-24 maanden voorafgaande aan het infarct. Eveneens hadden vrouwen met AP meer last gehad van slapeloosheid.

\section{B.3. Prospectief onderzoek}

Naast de eerder aangehaalde RCSS zijn er verschillende andere prospectieve onderzoeken uitgevoerd waarin de relatie tussen slaap en slaapproblemen en het hartinfaret werden bestudeerd (Thomas et al., 1973; Floderus, 1974; Friedman et al., 1974; Vanhala, 1979; Siegrist et al., 1986).

In het Amerikaanse onderzoek van Thomas et al. (1973) vulden 1337 studenten van John's Hopkins Medical College van 1948-1964 een vragenlijst in, 
welke een groot aantal fysiologische, psychologische en biologische variabelen bevatte. Met betrekking tot de slaap werd gevraagd "Bent U nog moe bij het wakker worden", en "Heeft U last van slapeloosheid". De algemene vraagstelling van dit onderzoek luidde of er psychologische voorspellers voor bepaalde ziekten te onderkennen waren. In 1971 werden de antwoorden van suïcidegevallen $(\mathrm{N}=9)$, en van personen die aan hypertensie leden $(N=9)$, ernstige psychische problemen $(\mathrm{N}=9)$, hartlijden $(\mathrm{N}=8)$, of een tumor $(\mathrm{N}=9)$ hadden gekregen, vergeleken met hen die gezond gebleven waren. Ten aanzien van de slaapproblemen werd geconstateerd dat de lijders aan coronaire hartziekte reeds vijftien jaar voor hun ziekte vaker over moe wakker worden en opstaan klaagden, en degenen met ernstige psychische problemen over slapeloosheid of moe wakker worden.

Friedman et al. (1974) onderzochten Amerikaanse hartinfarctpatiënten $(\mathrm{N}=330)$, een coronaire risicogroep $(\mathrm{N}=349)$, en "gezonde" mensen $(\mathrm{N}=345)$. De personen in de risicogroep hadden een verhoogde kans op het krijgen van een hartinfarct, omdat zij rookten, en een verhoogd serumcholesterol- en glucosegehalte, verhoogde bloeddruk, en ECG-afwijkingen hadden. Alle groepen waren vergelijkbaar met betrekking tot geslacht, etnische achtergrond en leeftijd. In de periode 1964-1970 had iedereen een zeer uitvoerige vragenlijst ingevuld waarin o.a. Type A gedrag, "stress", emotionele uitputting, angst, neuroticisme en slaapklachten (d.w.z. problemen met inslapen, doorslapen, en vermoeid wakker worden) aan de orde kwamen. Infarctpatiënten klaagden in vergelijking met de anderen vaker over inslaapproblemen ( $21 \%)$, vergeleken met respectievelijk $14 \%$ en $15 \%$ in de risico- en gezonde groep, doorslaapproblemen $(20 \%$, respectievelijk $15 \%$ en $14 \%$ ), en zij werden tevens vaker 's morgens moe en uitgeput wakker ( $28 \%$, respectievelijk $21 \%$ en $21 \%$ ). Behalve bij Friedman et al.(1974) werden angst, depressie, neuroticisme en slaapproblemen als belangrijke determinanten van het hartinfarct ook in Zweeds prospectief onderzoek gevonden (Floderus, 1974).

Siegrist et al. (1982, 1987(a)), tenslotte, onderzochten o.a. middels een gestructureerd interview bij 416 Duitse "blue collar workers" in hoeverre een aantal psychosociale factoren een rol speelden bij het ontstaan van een hartinfarct. Het ging hierbij om slaap, werkomstandigheden, beroepscarriere, interpersoonlijke moeilijkheden, "social support", negatieve levensgebeurtenissen, en "need for control". De periode vóór het infarct kenmerkte zich door controleverlies m.b.t. bepaalde gebeurtenissen, waarbij men de eisen die door de omgeving gesteld werden, niet meer aan kon. Na overmatige inspanning om deze controle toch te behouden, belandde men tenslotte in een uitputtingsfase: Siegrist noemt dit "immersion". Daarbij werd gevonden dat degenen die hoger scoren op de factor "immersion" 's nachts vaker wakker werden. Tesamen met het optreden van "immersion" komen in toenemende mate slaapproblemen voor.

Prospectief onderzoek geeft ook een indicatie dat snurken het risico op een infarct verhoogt, onafhankelijk van gewicht, hoge bloeddruk, roken en alcoholgebruik (Koskenvuo et al., 1987). Dit verhoogde risico voor het krijgen van hart- 
en vaataandoeningen bij snurkers kan het best verklaard worden door een directe samenhang met slaapapneu, hoewel snurken ook een moderator zou kunnen zijn. Zo is gevonden dat alcoholgebruik de relatie tussen snurken en coronaire sterfte kan verklaren (Hennekens et al.,1979). Alcoholgebruik kan ook slaapapneu bij gezonde mannen en chronische snurkers tot gevolg hebben (Taasan et al., 1981; Issa \& Sullivan, 1982), terwijl de duur en de frequentie van de aanvallen bij de slaapapneu-patiënt toeneemt bij alcoholgebruik (Issa \& Sullivan, 1982). De relatie tussen snurken en het hartinfarct verdient verder onderzocht te worden, zoals in dit onderzoek zal gebeuren. Volgens Waller \& Bhopal (1989) is het echter nog te prematuur om van een causale factor voor het hartinfarct te spreken. Zij geven meerdere verklaringen voor de relatie tussen snurken en het hartinfarct, te weten, toeval, "bias", snurken als gevolg van het infarct, en "confounding". De eerste verklaringsmogelijkheid: toeval lijkt zeer onwaarschijnlijk: de meeste gevonden odds ratio's m.b.t. de samenhang tussen snurken en het hartinfarct en andere cardiovasculaire aandoeningen zijn significant groter dan 1. Bij de tweede mogelijke verklaring wordt allereerst informatie "bias"genoemd: personen die daadwerkelijk ziek zijn, geven eerder aan dat zij snurken, omdat zij zich er mogelijk meer bewust van zijn. Daarnaast zou de samenhang verklaard kunnen worden door selectie "bias", en tenslotte kan er sprake zijn van interviewer "bias", omdat deze op de hoogte was van de vraagstelling. De derde verklaringsmogelijkheid is eveneens onwaarschijnlijk omdat ook in prospectief onderzoek is aangetoond, dat snurken het risico op cardiovasculair lijden verhoogt. Tenslotte blijken leeftijd, geslacht, gewicht en roken het relatieve risico dat samenhangt met snurken weliswaar te verlagen, maar het blijft significant verhoogd. Er is geen sprake van "confounding". Snurken en slaapapneu zijn dus mogelijke risicoindicatoren voor het hartinfarct, die verder onderzoek rechtvaardigen.

\section{Samenvatting}

De resultaten van vele verschillende soorten onderzoek geven aan dat slaapproblemen, d.w.z. vooral inslaap- en doorslaapproblemen, en moe wakker worden een risicoindicator voor het hartinfaret vormen. Dit zou ook kunnen gelden voor snurken en slaapapneu. Al deze vragen zijn echter nog weinig systematisch onderzocht:

\section{4. "NEED FOR CONTROL"}

Het onderzoek naar de relatie tussen bepaalde persoonlijkheids-kermerken en een verhoogd infarct-risico heeft zich oorspronkelijk vooral gericht op het Type A gedrag. Dit wordt gekenmerkt door een combinatie van eigenschappen als ambi- 
tie, agressie, wedijver, en ongeduld, en door specifieke gedragingen als voortdurende onrust, alertheid, gejaagdheid, een verhoogd werktempo en een typerende stijl van spreken. Ook kunnen er bepaalde emotionele reacties optreden zoals irritatie en een toename in boosheid en vijandigheid (Rosenman, 1983). Verder vermeldt Rosenman dat Type A personen op een specifieke manier omgaan met belastende gebeurtenissen in hun omgeving, waarbij zij de behoefte hebben deze gebeurtenissen zoveel mogelijk te controleren. Deze relatie tussen enerzijds Type A gedrag en anderzijds belastende eisen vanuit de omgeving is vooral door Glass (1977) uitvoerig beschreven.

Glass beschouwt Type A gedrag niet als een geisoleerde persoonlijkheidstrek van het individu maar als gedrag dat zich openbaart bij bepaalde personen wanneer er bijzondere omgevingscondities optreden. Er is sprake van een interactie tussen een bepaalde predispositie en kenmerken van de omgeving: door Type A gedrag te vertonen is men succesvol in staat controle te verwerven en/of te handhaven. Type A personen zullen er doorgaans dan ook alles aan doen om deze controle uit te oefenen, ongeacht de belemmeringen die zich daarbij kunnen voordoen. In de optiek van Glass zou de periode voorafgaande aan het infarct zich door "fear of losing control" kenmerken. Deze angst kan zich op verschillende wijzen uiten. Zo is er sprake van een toenemende geïrriteerdheid, boosheid en vijandigheid en is men niet meer in staat zich te ontspannen. "Loss of control" is volgens Glass daarmee een mogelijke determinant van zowel het hartinfarct als de plotselinge cardiale dood. Dit controleverlies gaat gepaard met toenemende frustratie, demoralisatie, en uitputting.

Siegrist en medewerkers hebben zich met name gericht op de cognitieve componenten en perceptuele gevolgen van deze dominante behoefte om controle te handhaven (Matschinger et al., 1986). Volgens hen blijken bepaalde problematische ervaringen niet op de juiste wijze te worden geïnterpreteerd door personen met een sterke behoefte om controle te handhaven. Hun cognitieve systeem zou zich op een dusdanige wijze hebben ontwikkeld dat er (voortdurend) verkeerde inschattingen worden gemaakt. Eisen uit de omgeving worden daarbij onderschat en de eigen "coping"-mechanismen overschat. Deze grote inspanning noemen Siegrist et al. "vigor". Ook de emotionele consequenties van het eigen gedrag worden hierbij onderschat. Wanneer dit uiteindelijk leidt tot toenemend controle-verlies, en zelfs tot het staken van de strijd, wordt dit "immersion" genoemd, zoals eerder aangegeven (1.1). Zowel in retrospectief als prospectief onderzoek is de betekenis van het concept in relatie tot het hartinfarct bestudeerd. Er werd een onderscheid gemaakt tussen enerzijds cognitieve factoren, met name cognities die te maken hebben met niet geslaagd "coping" gedrag en anderzijds emotionele factoren, zoals "loss of control", ontevredenheid, en vermoeidheid.

In het retrospectieve onderzoek met als vraagstelling: Is een afgenomen kwaliteit van leven een risicoconditie, voor het krijgen van een cardiovasulaire aandoening, werden 380 mannen met een eerste infarct en 190 "gezonde" mannen, 
bestudeerd, vergelijkbaar qua leeftijd en beroep (Siegrist, 1984). Van deze mannen was $20 \%$ ongeschoold of semi-geschoold, $23 \%$ was geschoold "blue-collar worker", $41 \%$ "white collar worker", 10\% was academisch gevormd en ook als zodanig werkzaam en $6 \%$ was "official". Bij eenderde was er sprake van wisselende diensten en bij eenvierde van lopende band-werk. In het onderzoek werd eveneens gekeken naar de invloed van de werklast. De "kwaliteit van leven" werd bepaald door de mate van algemeen welzijn, tevredenheid, participatie in sociale activiteiten, sexueel functioneren, vitaliteit, en arbeidslust. De samenhang tussen sociale en emotionele problemen, welke een gevolg zijn van de werklast, onprettige werkomstandigheden en interpersoonlijke conflicten, en de kwaliteit van leven werd eveneens aan de orde gesteld. De hartinfarctpatiënten gaven aan significant vaker naar ander werk te hebben moeten uitzien, een zwaardere werkdruk te ervaren, alsmede een grotere tijdsdruk. Een sterke mate van "Need for Control" kwam als "coping"-mechanisme vooral in deze groep voor.

Of "Need for Control" als zodanig een verhoogd risico voor het krijgen van een hartinfarct kan inhouden, werd vervolgens onderzocht in een prospectieve studie, waarbij gebruik werd gemaakt van een vragenlijst waarmee men "Kontrollambitionen" kon meten (Siegrist et al., 1987(b)). In dit onderzoek werden 416 mannelijke "blue-collar workers" in de leeftijd van 25 tot 55 jaar gedurende een periode van enkele jaren gevolgd. De resultaten tonen aan dat het risico op een hartinfarct verhoogd is bij diegene waar sprake is van toegenomen werkdruk, problemen op het werk en "need for control". Deze veranderingen leiden tot een toename in "active distress". Bij de patiënten was er tevens sprake van een toename in slaapproblematiek, welke niet samenhing met lichamelijk lijden. Het gaat hierbij om doorslaapproblemen, d.w.z. 's nachts wakker worden en 's morgens te vroeg wakker worden. Tenslotte was er sprake van emotionele veranderingen, boosheid en hopeloosheid, in het jaar voorafgaande aan de ziekte (Siegrist, 1990).

\subsection{SAMENVATTING}

In het onderhavige onderzoek zal getracht worden bovengenoemde bevindingen m.b.t. vitale uitputting te repliceren. Bovenal zal een element van dit syndroom systematisch onderzocht worden. Hierbij gaat het om het bepalen van het risico op een hartinfarct van specifieke chronische slaapklachten, daar deze nadelige consequenties kunnen hebben voor de gezondheid. Welke slaapklachten het risico verhogen is echter niet altijd geheel duidelijk. Dit onderzoek naar slaapklachten zal daarom zowel toetsend als exploratief van aard zijn.

Dit onderzoek bestudeert eveneens de vraag of hartinfaretpatiēnten verschillen van controles m.b.t. tot "Need for Control". Bovendien is het voor het eerst mogelijk de relatie tussen slaapklachten, vitale uitputting en "need for control" 
tegelijkertijd te onderzoeken, waardoor mogelijke verbanden tussen deze concepten gevonden kunnen worden. Dit gedeelte van het onderzoek zal echter slechts summier worden uitgewerkt, daar deze thematiek eigenlijk een ietwat andere aanpak vereist dan die welke gebruikt is in het onderhavige onderzoek. 



\section{HOOFDSTUK 2}

\section{ONDERZOEK NAAR SLAAPKLACHTEN: \\ EEN LITERATUUROVERZICHT}

\subsection{INLEIDING}

In dit hoofdstuk wordt allereerst onderzoek beschreven waarin het voorkomen van slaapklachten in de algemene bevolking werd bestudeerd, teneinde een vergelijking te kunnen maken met de resultaten van het onderhavige "case-control" onderzoek. Voornoemd bevolkingsonderzoek wordt gekenmerkt door een weinig systematische aanpak, hetgeen al eerder werd opgemerkt m.b.t. de studies naar de relatie tussen slaapklachten en het hartinfarct. De inventarisatie van slaapklachten gebeurt veelal aan de hand van globale vragen; er zijn slechts weinig studies waarin op systematische wijze problemen met de nachtelijke slaap, met het wakker worden en het opstaan, en met het functioneren overdag zijn uitgewerkt. Dit hangt mogelijke samen met het feit dat pas in de jaren zeventig een begin werd gemaakt met de systematische beschrijving van diverse slaapproblemen en de ontwikkeling van een passend classificatiesysteem.

Een globale ordening van slaapklachten wordt gegeven door Williams et al. (1978) en Hartmann (1980). Williams et al. onderscheiden primaire en secundaire slaapstoornissen, parasomnia's, en een verzameling van overige stoornissen. Met primaire slaapklachten worden die stoornissen bedoeld waarbij geen achterliggende aandoening bekend is, terwijl aan secundaire klachten een lichamelijke of psychische stoornis ten grondslag ligt. Hartmann gaat uit van een driedeling: insomnia, hypersomnia, en parasomnia. Naast deze globale indelingen zijn er twee uitgebreide classificatiesystemen ontwikkeld: de American Sleep Disorders Centers (ASDC)-classificatie en de International Classification of Diseases, 9th Revision, Clinical Modification (ICD-9-CM). Beide systemen zijn vooral geschikt voor het klinisch diagnostisch onderzoek van slaapproblemen, maar te uitgebreid voor epidemiologisch onderzoek.

Naast het feit dat het meeste onderzoek naar het voorkomen van slaapklachten niet is uitgegaan van een van beide classificatiesystemen, is ook de dataverzameling doorgaans weinig systematisch uitgevoerd. Allereerst zijn de vragen 
over het algemeen globaal geformuleerd en zijn de resultaten van onderzoek soms slechts gebaseerd op een enkele vraag. Zo vroeg bijv. Partinen (1982) enkel hoe men over het algemeen sliep. Verder kunnen verschillen tussen onderzoeken worden verklaard doordat vragen en/of antwoordcategoriëen meestal niet met elkaar overeenkomen. Tenslotte kan het verschil in uitkomsten te wijten zijn aan het feit dat er geen duidelijk onderscheid gemaakt wordt tussen enerzijds de frequentie van een klacht en anderzijds de intensiteit. In het onderhavige onderzoek wordt hier nadrukkelijk aandacht aan besteed. Gezien dus het belang van de wijze waarop tot nu toe data m.b.t. het voorkomen van slaapklachten zijn verzameld zal in paragraaf 2.6 afzonderlijk aandacht worden besteed aan de gebruikte meetmethoden. Omdat in de onderhavige studie, geen fysiologisch slaaponderzoek is opgenomen, wordt deze methode om slaap te meten verder niet besproken.

De opbouw van dit hoofdstuk is verder als volgt. Paragraaf 2.2. gaat in op de ordening van slaapklachten, waarbij de twee classificatiesystemen ASDC en ICD-9-CM worden besproken. Paragraaf 2.3. geeft een overzicht van het onderzoek dat gedaan is naar het voorkomen van slaapklachten in de algemene bevolking. De klachten die daarbij het meest voorkomen, d.w.z. insomnia en hypersomnia, worden in paragraaf 2.4. beschreven. Paragraaf 2.5. bespreekt summier enkele mogelijke oorzakelijke factoren van slaapklachten. Omdat het meten van slaapklachten veelal gebeurt aan de hand van vragen (al of niet gestructureerd), gaat paragraaf 2.6. in op de verschillenden wijzen waarop slaapklachten gemeten worden. De wijze waarop de aanwezigheid van slaapapneu middels vragen kan worden achterhaald, komt afzonderlijk aan bod in paragraaf 2.7. Deze paragraaf geeft eveneens aan om welk klachtenpatroon het hier gaat. Tenslotte sluit paragraaf 2.8. het hoofdstuk af met een overzicht.

\subsection{DE CLASSIFICATIE VAN SLAAPKLACHTEN}

Het onderzoek naar slaap en slaapproblemen heeft zich in de afgelopen decennia sterk ontwikkeld. Het wetenschappelijk fundament ervoor is gelegd in de periode waarin Aserinsky \& Kleitman de REM-slaap ontdekten (1953). Een volgende belangrijke stap werd gezet met de definiëring van de verschillende slaapstadia door Rechtschaffen en Kales (1968). In deze periode ontbrak zowel enigerlei gemeenschappelijke terminologie als een geaccepteerd classificatiesysteem voor de ordening van slaapklachten. De eerste stap hiertoe werd gezet tijdens de $10 \mathrm{e}$ bijeenkomst van de "Association for Psychophysiological Study of Sleep" (APSS) in 1972. Dit kreeg een vervolg door de oprichting in 1976 van een studiegroep voor het ontwikkelen van een diagnostisch systeem voor slaap- en waakstoornissen door de "American Association of Sleep Disorders Centers" (ASDC). Alvorens dit gepubliceerd werd, kwamen Williams en Karacan in 1978 met een eigen classificatie- 
systeem, hoewel zij melding maakten van het te verwachten systeem van de ASDC. Dit laatste document: "Diagnostische classificatie voor slaap- en waakstoornissen" werd een jaar later gepubliceerd (Roffwarg, 1979).

\section{A. Het systeem van de American Association of Sleep Disorders Centers (ASDC)}

In dit systeem zijn slaapklachten niet op grond van etiologische factoren gegroepeerd, maar op basis van symptomen, omdat er nog onvoldoende bekend was over oorzakelijke factoren. Daarnaast waren er niet altijd eenduidige oorzaken voor bepaalde klachten aan te wijzen.

De ASDC classificatie bestaat uit 4 categoriëen: (A) "Disorders of Initiating and Maintaining Sleep (DIMS)", waartoe inslaap- en doorslaapproblemen behoren; (B) "Disorders of Excessive Somnolence (DOES)", vooral hypersomnia; (C) "Disorders of Sleep-Wake Schedule (SWSD)", dwz. stoornissen in de slaap-waak cyclus; en (D) "Parasomnia", een verzamelterm voor problemen geassocieerd mei slaap, slaapstadia en tijdelijke "arousals". De categoriëen C en D zijn niet samengesteld aan de hand van specifieke symptomen, maar op grond van pathofysiologische processen die optreden tijdens de slaap. Alle groepen zijn onderverdeeld in een aantal subcategoriëen. Insomnia en hypersomnia zijn in het ASDC-systeem opgenomen als twee aparte groepen. Volgens meerdere onderzoekers is dit een kunstmatig onderscheid, omdat insomniaklachten in veel gevallen hypersomnia veroorzaken, en omgekeerd (Kales, A. et al., 1980). De reden om insomnia en hypersomnia toch in aparte groepen onder te brengen is gelegen in de omstandigheid dat op grond van de symptomen een dergelijk onderscheid wel degelijk te maken is. Personen klagen doorgaans of meer over problemen met de nachtelijke slaap, of zij geven aan problemen te hebben met vermoeidheid en/of slaperigheid overdag.

De bruikbaarheid van het ASDC-systeem is getoetst in een aantal studies (Coleman et al , 1982, 1983). Hierbij werden ruim 8000 volwassen personen, opgenomen in ruim twintig slaapklinieken, gediagnosticeerd. De meest voorkomende klacht bleek "slaperigheid overdag" (behorend tot DOES), gevolgd door "problemen met de nachtelijke slaap" (onderdeel van DIMS) en tens!otie de parasomnia's en de SWSD. De bruikbaarheid van dit systeem is redelijk. Reynolds (1981) en Williams et al. (1988) vermelden dat zij, m.b.v. het ASDC-systeem slaapklachten in het algemeen goed kunnen diagnosticeren. Onderzoek van Hauri (1983) wees uit dat het aan de hand van dit systeem bijv. goed mogelijk was om personen op te sporen met een psychofysiologische insomnia die was ontstaan in de kinderjaren. Het systeem sluit echter weinig aan bij de moderne ontwikkelingen in de psychiatrische diagnostiek. 


\section{B. De International Classification of Diseases, 9th Revision, Clinical Modification (ICD-9-CM)}

Deze classificatie van de Wereld Gezondheidsorganisatie (1978) kent twee secties voor slaapproblemen: "Mental Disorders" (codes $307.40 \mathrm{t} / \mathrm{m}$ 307.49) en "Symptoms, Signs and III-Defined Conditions" (codes $780.50 \mathrm{t} / \mathrm{m}$ 780.59). Een aantal slaaponderzoekers (bijv. Kales, J., et al., 1982, Kales, A., et al., 1984) geeft de voorkeur aan het ICD-9-CM- boven het ASDC-systeem, met als belangrijk argument dat de ASDC-classificaties onverenigbaar zijn met die van de DSM-III (1980). De ASDC-classificatie is als appendix opgenomen bij de DSM-III. Daarnaast zijn volgens deze onderzoekers een aantal ASDC-categoriëen tot stand gekomen op basis van onvolledige of anecdotische informatie; zo zijn bepaalde neurofysiologische diagnoses nogal hypothetisch van aard. Het grote voordeel van het onderbrengen van slaapstoornissen in de ICD-9-CM is dat er geen apart classificatiesysteem nodig is, het is dus praktischer. Daarmee wordt de ICD-9-CM veelvuldig gebruikt voor het diagnosticeren van slaapstoornissen en de DSM-III voor psychiatrische stoornissen die frequent samenhangen met slaapproblemen.

Binnen de ICD-9-CM worden slaapproblemen ingedeeld in twee groepen: (A) de niet-organische, en (B) de organische slaapproblemen. Bepaalde condities die kunnen optreden tijdens slapen en waken zijn in aparte categoriëen ondergebracht, zoals enuresis (307.6), bruxisme (306.8) en "head banging" (307.3), terwijl narcolepsie onderdak vindt bij de stoornissen in het CZS. uit:

De volledige ICD-9-CM classificatie van slaapproblemen ziet er als volgt

Tabel 2.1. Niet-organische slaapproblemen

307.40: Niet organische stoornissen, niet gespecificeerd

307.41: Tijdelijke problemen met in- en doorslapen

307.42: Chronische problemen met in- en doorslapen

307.43: Tijdelijke problemen met wakker worden of wakker blijven

307.44: Chronische problemen met wakker worden of wakker blijven

307.45: Slaap-waak stoornissen t.g.v. verstoringen in de 24 uurs slaap-waak cyclus

307.46: Somnambulisme of nachtelijke angst, en slaapwandelen

307.47: Andere dysfuncties van slaap stadia of ontwaken

307.48: Herhaaldelijke onderbrekingen van de slaap

307.49: Andere factoren

Kales et al. (1982) hebben enkele kleine veranderingen in deze classificatie aangebracht. De termen "insomnia" en "hypersomnia" worden respectievelijk gebruikt voor de categoriëen 307.41-.42 en 307.43-.44, terwijl categorie 307.48 vervalt, omdat herhaaldelijke onderbrekingen niet relevant zijn. Tenslotte is er een 
speciale categorie voor slaapapneu opgenomen. Na deze wijzigingen blijven er zeven categoriëen over: 1 : Tijdelijke insomnia; 2 : Chronische insomnia; 3 : Tijdelijke hypersomnia; 4: Chronische hypersomnia; 5: Slaap-waak-stoornissen t.g.v. verstoringen in de 24 uurs slaap-waak-cyclus; 6 : Somnambulisme of nachtelijke angsten; en 7: Andere dysfuncties van de slaap.

Tabel 2.2. Organische slaapproblemen

Wanneer de slaapproblemen van organische oorsprong zijn, wordt de volgende indeling gehanteerd:

780.50: Niet gespecificeerde slaapproblemen

780.51: Slapeloosheid met slaapapneu

780.52: Overige slapeloosheid

780.53: Overmatige slaap en slaperigheid met slaapapneu

780.54: Overige vormen van hypersomnie

780.55: Verstoring van de 24 uurs slaap-waakcyclus

780.56: Functiestoornissen welke verband houden met slaapstadia of het ontwaken uit de slaap

180.57: Overige gespecificeerde slaapstoornissen

\subsection{HET VOORKOMEN VAN SLAAPKLACHTEN IN DE ALGEMENE BEVOLKING}

Bij het onderzoek naar het voorkomen van slaapklachten in de bevolking valt op dat de vraagstellingen en de wijze van data-verzameling sterk van elkaar verschillen, waardoor het moeilijk is de resultaten onderling te vergelijken. Ondanks dit methodologische probleem is het van belang om te weten om welke klachten het precies gaat en hoe vaak deze voorkomen, teneinde een vergelijking te kunnen maken met de uitkomsten uit het onderhavige onderzoek.

Onderzoek in Nederland heeft aangetoond dat ongeveer $25 \%$ van de mensen die hun huisarts consulteren zichzelf beschouwen als een "matige" tot "slechte" slaper (de Graaf et al., 1981). Uit soortgelijk Amerikaans onderzoek blijkt dat 17\% van de patiënten insomniaklachten rapporteerden, $4 \%$ last had van nachtmerries, $3 \%$ klaagden over hypersomnia, $2 \%$ over enuresis, $1 \%$ over nachtelijke angsten, $0.6 \%$ over slaapwandelen en narcolepsie (onbedwingbare slaapaanvallen overdag) (Bixler et al., 1979(a)). Van deze klachten komen insomnia, nachtmerries en hypersomnie ook het meest voor bij psychiatrische patiënten (Bixler et al., 1979a). Eerder onderzoek in de algemene. Amerikaanse bevolking wees uit dat $14 \%$ tot $35 \%$ van de volwassenen klachten over slapeloosheid heeft (Hammond et al.1964; Balter et al., 1974, Karacan et al., 1976(b); Bixler et al., 1979a), terwijl andere studies vonden dat ongeveer $6 \%$ tot $12 \%$ van de volwassen mannen inslaapproblemen heeft (Karacan et al., 1983; Welstein et al., 1983) en 6\% insomniaklachten (Kripke et al., 1979; Lavie, 1981; Partinen et al., 1983). Het meest recente onder- 
zoek naar het voorkomen van slaapklachten in de algemene Nederlandse mannelijke bevolking werd gedaan door Van Diest et al. (1989). Tabel 2.3. vermeldt de resultaten.

Tabel 2.3. Slaapklachten in de algemene Nederlandse mannelijke bevolking (Bron: Van Diest et ul., 1989)

Problemen met:

$\begin{array}{lr}\text { inslapen } & 13 \% \\ \text { doorslapen } & 10 \% \\ \text { te vroeg wakker worden } & 6 \% \\ \text { moeilijk wakker worden } & 4 \% \\ \text { 's morgens vermoeid opstaan } & 7 \% \\ \text { slaperigheid overdag } & 13 \% \\ \text { vermoeidheid overdag } & 13 \%\end{array}$

Men mag dus op grond van deze en de vorige studies concluderen dat DIMS-klachten de meest voorkomende problemen zijn (Karacan et al., 1976(b); Bixler et al., 1979(b)).

Onderzoek naar het voorkomen van slaperigheid overdag wees uit dat ongeveer $4 \%$ van de volwassenen hierdoor geplaagd wordt (Bixler et al., 1976; Karacan et al., 1976(b); Coleman et al., 1980; Lavie 1981; Hetta et al., 1985). Over het voorkomen van stoornissen in de slaap-waak cyclus en parasomnias is niet veel geschreven. Van de onderzochte volwassenen geven $2 \%$ tot $5 \%$ aan last te hebben van slaapwandelen en nachtelijke angsten (Kales et al., 1987), terwijl 10\% in het verleden of op dit moment last had of heeft van nachtmerries of angstaanjagende dromen (Bixler et al., 1979b). Daarnaast zijn er een aantal studies gedaan naar het specifieke voorkomen van narcolepsie en slaapapneu (stoppen van de ademhaling) in de bevolking. In Amerika komt narcolepsie bij 1 op de 2000 volwassenen voor (Williams et al., 1988). In Israelisch onderzoek van Lavie (1983) werd gevonden dat apneu bij $1 \%$ van de mannelijke populatie voorkomt, hetgeen overeenkomt met de uitkomsten van onderzoek in Finland (Telakivi et al., 1987(a)) en Italie (Cirignotta et al., 1988). In dit laatste onderzoek werd de hoogste prevalentie van slaapapneu, te weten 2 tot $5 \%$, gevonden bij mannen tussen de 40 en 60 jaar. Narcolepsie en slaapapneu gaan doorgaans gepaard met hypersomniaklachten: Coleman et al.(1982) vonden dat in een groep volwassenen met "Excessive Daytime Sleepiness" (EDS) $43 \%$ als slaapapneu- en $25 \%$ als narcolepsiepatiënt gediagnosticeerd was. Bij de apneupatiënt kan er tevens sprake zijn van problemen met de nachtelijke slaap. Kenmerkend voor apneu is het 's nachts tijdens de slaap hevig en frequent snurken. Over dit laatste verschijnsel is epidemiologisch onderzoek verricht, dat voor de onderhavige studie van bijzonder belang is, omdat het aantoonde dat er een positieve samenhang is tussen snurken en cardiovasculaire aan- 
doeningen, zoals het hartinfarct (Lugaresi et al., 1980; Partinen et al. 1983; Norton et al., 1985; Telakivi et al., 1987(b)). Uit ander onderzoek, waarin aan zowel mannen als hun partners werd gevraagd of zij snurkten, bleek dat $34 \%$ van de mannen en $18 \%$ van de vrouwen snurkten (Wiggins et al., 1990).

Het onderzoek naar slaap in de algemene bevolking heeft zich verder nog gericht op de relatie tussen slaapduur en morbiditeit en/of mortaliteit. Mannen ouder dan 30 jaar, die gemidddeld 4 uur per nacht sliepen, hadden een bijna drievoudig verhoogd relatief risico om binnen 6 jaar te sterven dan zij die gemidddeld 7-8 uur sliepen; voor vrouwen bedroeg dit risico 1.5. Personen die meer dan 10 uur sliepen hadden eveneens een verhoogde sterftekans, die zowel voor mannen als vrouwen 1.8 bedroeg (Kripke et al., 1979). Ook uit andere studies blijkt dat sterfte als gevolg van een hartziekte, of beroerte, kanker, of suicide samenhangt met extreem kort of lang slapen (Partinen, 1982; Wingard \& Berkman, 1983). In het algemeen hangt meer dan 9 uur of minder dan 6 uur slapen samen met een relatief risico van 1.7 of hoger, vergeleken met volwassen personen die 7-8 uur sliepen (Hammond, 1964; Wingard et al.,1982, 1983).

\section{Samenvatting}

Zowel uit nationaal als internationaal onderzoek blijken DIMS-klachten het meest frequent voor te komen. In de algemene bevolking heeft $6 \%$ tot $35 \%$ van de volwassenen problemen met de nachtelijke slaap. Hypersomnia komt minder frequent voor in de algemene bevolking te weten tussen de $4 \%$ en $6 \%$. Wanneer er sprake is van hypersomnia wordt dit voornamelijk verklaard door slaapapneu. Hevig snurken vormt hiervan de centrale klacht. Snurken als zodanig komt bij $34 \%$ van de mannen en bij $18 \%$ van de vrouwen voor. In Nederlands onderzoek blijkt dit percentage bij mannen hoger te liggen, te weten $59 \%$ (van Diest, 1993).

Onderzoek naar het voorkomen van slaapklachten behorende tot de laatste categoriëen van de ASDC, te weten stoornissen in het slaap-waak-ritme en de parasomnia's, zijn nagenoeg niet gedaan. Wat de slaapduur betreft, blijkt dat 7 tot 8 uur slapen doorgaans als referentiepunt dient in het onderzoek naar de relatie tussen slaapduur en mortaliteit en/of morbiditeit. In het onderhavige onderzoek zal hier eveneens van worden uitgegaan.

\subsection{INSOMNIA EN HYPERSOMNIA}

Omdat insomnia- en hypersomniaklachten in het hierna te bespreken onderzoek een centrale plaats innemen, worden deze hier gedetailleerder beschreven om te bezien wat deze klachten precies inhouden. 


\section{A. Insomnia}

Insomnia is een klachtenpatroon, dat uit een groep van onderling saneenhangende symptomen bestaat, te weten inslaap- en/of doorslaapproblemen en/of problemen met 's morgens te vroeg wakker worden (Roffwarg, 1979; Kales, J., et al., 1984; Parkes, 1985; Morin et al., 1988 ; Williams et al., 1988; Manfredi et al., 1989).

Problemen met inslapen worden uitgedrukt in een langere slaaplatentietijd, d.w.z. de tijd die verloopt tussen het willen gaan slapen en het daadwerkelijk in slaap vallen. Parkes (1985) en Morin et al., (1988) vinden dat er bij een slaaplatentietijd van 30 minuten of meer sprake is van een inslaapprobleem, hoewel Williams et al., (1988) van mening zijn dat er geen eenduidige maatstaven zijn aan te geven. Een langere latentietijd hoeft volgens hen niet altijd te betekenen dat er daadwerkelijk een inslaapprobleem is. Sommige personen vinden het niet erg om er een uur over te doen alvorens in te slapen, terwijl anderen het reeds als een probleem ervaren om 10 minuten wakker liggen.

Er is sprake van een doorslaapprobleem wanneer men - nadat men is ingeslapen - wakker wordt, en vervolgens niet meer in slaap kan komen. Morin et al., (1988) geven aan dat er sprake is van een doorslaapprobleem wanneer men frequent en volledig wakker wordt en langer dan 30 minuten wakker is gedurende de nacht. Evenals bij de inslaapproblemen is er vaak een discrepantie tussen de gerapporteerde klacht en datgene wat er in het onderzoek objectief gevonden wordt (bijv. het aantal malen dat men wakker wordt). Ook hier zijn Williams et al. (1988) en Morin et al. (1988) het oneens; de eersten zien weinig heil in het zelf noteren van het aantal keren dat men 's nachts wakker wordt, terwijl Morin et al. (1988) aangeven dat er sprake is van doorslaapproblemen wanneer men frequent en volledig wakker wordt en langer dan 30 minuten wakker is gedurende de nacht.

De klacht 's morgens te vroeg wakker te worden is, tenslotte in feite een doorslaapprobleem, omdat er sprake is van een lange periode van wakker zijn, zonder dat men opnieuw in slaap kan vallen. Morin et al. (1988) specificeren deze klacht nader als 's morgens te vroeg wakker worden na minder dan 6,5 uur geslapen te hebben. Dat bij insomnia eveneens gekeken moet worden naar de totale slaapduur wordt aangegeven door Kripke et al. (1979). Volgens hen is er pas sprake van insomnia wanneer er ook sprake is van een te korte slaapduur.

Naast problemen met inslapen, doorslapen, en te vroeg wakker worden, blijken klachten over vermoeidheid bij het opstaan ook veelvuldig vermeld te worden door personen met doorslaapproblemen: Ondanks het feit dat men goed geslapen heeft, voelt men zich moe (Williams et al., 1988). Parkes (1985) geeft aan dat het vermoeid zijn bij het opstaan in feite een gevolg is van een slechte slaap. De insomniapatiënt geeft tevens aan 's morgens vaker moe te zijn, vergeleken met 
hen die geen insomniaklachten hebben. Deze laatsten klagen eerder over vermoeidheid aan het einde van de dag.

\section{Samenvatting}

Er is sprake van insomnia wanneer niet alleen de slaap verstoord is, maar ook het functioneren overdag nadelig wordt beïnvloed. Men klaagt daarbij meestal over slaperigheid overdag, lichamelijke en geestelijke vermoeidheid, en onrust en angst, en men geeft tevens aan sneller prikkelbaar en opvliegend te zijn.

\section{B. Hypersomnia}

Evenals insomnia is hypersomnia een probleem dat iemand letterlijk dag en nacht kan bezighouden. Het slecht functioneren overdag kan het gevolg zijn van insomniaklachten, terwijl anderzijds hypersomnia de nachtelijke slaap in nadelige zin kan beïnvloeden. Er is sprake van hypersomnia in strikte zin wanneer de volgende klachten worden gerapporteerd: (1) overmatige slaperigheid overdag; (2) op ongewenste tijdstippen in slaap vallen; (3) sufheid overdag; en (4) de mogelijkheid van comateuze aanvallen. Dit criterium komt voornamelijk voor bij patiënten met narcolepsie (Roffwarg, 1979; Parkes, 1985; Williams et al., 1988). Naast deze centrale klachten klagen hypersomniapatiënten verder over vermoeidheid en energieverlies, voelen zij zich erg slap, en kan er sprake zijn van "black-outs" en leerproblemen. In dit verband zijn er veelvuldig geheugendysfuncties gerapporteerd (Williams et al., 1988).

Een groot probleem bij het diagnostiseren van hypersomnia is dat de termen "vermoeidheid" en "slaperigheid" door elkaar worden gebruikt. Slaperigheid overdag maar niet vermoeidheid overdag, is de centrale klacht van hypersomniapatiënten. Vermoeidheid is een klacht die eerder het gevolg is van een slechte slaap en dus eerder samenhangt met insomnia (Kales, J., et al., 1984). Door ondermeer aan patiënten te vragen of men wel eens in slaap valt wanneer men ontspannen is, bijv. wanneer men een boek leest of televisie kijkt, kan slaperigheid overdag het best worden gemeten.

\subsection{OORZAKELIJKE FACTOREN VAN SLAAPKLACHTEN} worden.

Het ontstaan van slaapproblemen kan op verschillende wijzen verklaard 


\section{A. Persoonlijkheidsfactoren}

$\mathrm{Er}$ is enig onderzoek dat heeft uitgewezen dat persoonlijkheidsfactoren een oorzaak van slaapproblemen kunnen zijn. Volgens studies van Kales et al. (1976) en Bixler et al. (1977) internaliseren insomnia- patiënten hun psychologische problemen, hetgeen "arousal" kan veroorzaken, terwijl Hicks et al. (1980, 1982) en Thoresen et al. (1980) vonden dat Type A personen, in vergelijking met hen die geen Type A zijn, korter slapen.

\section{B. Psychiatrische en psychofysiologische stoornissen}

Psychiatrische en psychofysiologische stoornissen blijken echter de meest voorkomende oorzaken te zijn van in- en doorslaapproblemen (Seidel et al., 1982). Deze auteurs beschrijven aan de hand van de ASDC-classificatie de mogelijke oorzakelijke factoren van tijdelijke insomnia. Dit kan een gevolg zijn van: (1) lawaai; (2) emotionele problemen; (3) angst; en/of (4) zorgen. (5) Het kan ook worden beschouwd als een reactie op "stress", bijv. als gevolg van problemen op het werk, interpersoonlijke conflicten, financiële problemen, of andere belangrijke ingrijpende levensgebeurtenissen. Tennslotte kan tijdelijke insomnia een gevolg zijn van (6) een verandering in de slaap-waak-cyclus, bijv. door variabele werktijden (Johnson et al., 1981; Moore-Ede et al., 1982).

Chronische insomnia kan een gevolg zijn van tijdelijke insomnia. Bepaalde cognitieve en omgevingsfactoren kunnen een stimulus zijn voor de eerder bestaande insominia-klacht (Kales \& Kales, 1984). Ook kunnen psychiatrische stoornissen chronische insomnia veroorzaken (Monroe \& Marks, 1977; Kales et al. , 1983). Zo gaan unipolaire affectieve stoornissen veelal gepaard met herhaald wakker worden, te vroeg wakker worden, een reductie van stadium 4-slaap, en een korte REM-latentie. Manie gaat gepaard met een volledige afname van de slaap. Kales et al. (1976) hechten sterke waarde aan psychologische factoren als oorzaak van insomnia.

Ademhalingsmoeilijkheden, bijv. als gevolg van slaapapneu, kunnen eveneens een oorzaak zijn voor slaapproblemen. Centrale slaapapneu gaat veelal gepaard met insomnia-klachten (Guilleminault, 1976, 1978, 1980). Personen lijdende aan centrale slaapapneu hebben geen problemen met inslapen, maar worden 's nachts herhaaldelijk wakker. Obstructieve slaapapneu gaat daarentegen voornamelijk gepaard met hypersomnia.

\section{Lichamelijke aandoeningen en overige factoren}

Ook lichamelijke aandoeningen kumnen een reden zijn voor het krijgen van slaapproblemen. Zo kan insomnia ook veroorzaakt worden door "nocturnal myoclonus" en/of het "restless legs"-syndroom. De eerste aandoening gaat gepaard met 
repeterende schokken in de beenspieren tijdens de slaap, terwijl het tweede syndroom wordt gekenmerkt door onaangename kriebelige gewaarwordingen in de benen bij het liggen of zitten. Personen die hieraan lijden klagen eveneens over slaperigheid overdag (Coleman et al., 1982(b)). Verder zijn het vooral pijn of lichamelijk ongemak die slaapproblemen veroorzaken (Berlin et al., 1984; Dicicco et al., 1987; Kales et al., 1987). Tenslotte worden het frequent gebruiken van medicijnen (Kales,A., 1980; Westermeyer, 1987; Dicicco et al., 1987), koffie (Karacan et al. 1976; Saywer et al., 1982; Istvan,et al.,1984) alcohol (Soldatos et al., 1980; Westermeyer, 1987) alsmede roken (Soldatos,et al., 1980; Istvan et al., 1984) als mogelijke oorzakelijke factoren genoemd.

In het onderhavige onderzoek wordt ook naar de oorzakelijke factoren van slaapklachten gevraagd. Teneinde een idee te krijgen van deze factoren zal enerzijds naar mentale factoren en anderzijds naar lichamelijke factoren worden gevraagd. Bovendien wordt nagegaan of er aanwijzingen zijn voor mogelijke mechanismen die de relatie tussen slaapklachten en het hartinfarct kunnen verklaren. Hierbij wordt de aandacht gericht op het voorkomen van klachten die samenhangen met slaapapneu. Verschillende studies hebben uitgewezen dat de samenhang tussen slaapklachten en het hartinfarct mogelijk hierdoor te verklaren valt (Lugaresi et al., 1980, 1982; Mondini et al., 1983; Burack, 1984; Siegrist et al., 1986, 1987(a)). De specifieke klachten die door slaapapneupatiënten worden gerapporteerd zullen daarom in paragraaf 2.7 nader worden uitgewerkt.

\subsection{MEETPROBLEMEN}

Deze paragraaf beschrijft de verschillende wijzen waarop de informatie in het besproken onderzoek naar slaapproblemen doorgaans is verzameld. Omdat er geen "objectieve" fysiologische metingen in het onderhavige onderzoek zijn uitgevoerd, worden alleen "subjectieve" meetmethoden besproken. Er kan sprake zijn van een discrepantie tussen de uitkomsten van onderzoek gebaseerd op objectieve en subjectieve meetmethoden (Williams et al., 1988), in die zin dat subjectieve methoden een overschatting van de problemen kunnen opleveren. Wanneer er echter op voldoende systematische wijze naar slaapklachten wordt gevraagd, is de subjectieve methode gerechtvaardigd (Mc Ghie et al.1962). Deze auteurs maakten bij het bestuderen van slaapklachten onderscheid tussen de kwantitieve en de kwalitatieve aspecten van de slaap. Onder de, eerste worden zoal doorgaans verstaan: de tijd die men nodig heeft om in te slapen, om wakker te worden, en/of de tijd die men nodig heeft om op te staan. Onder de kwalitatieve aspecten vallen beschrijvingen als lichte, normale of diepe slaap, herhaaldelijk en/of vermoeid wakker worden, of vermoeid zijn overdag. 
Een systematische aanpak in het onderzoek naar het voorkomen van slaapklachten in de algemene bevolking of naar de mogelijke relatie tussen slaapklachten en het hartinfarct is lang niet overal toegepast. Het inventariseren van slaapklachten in de algemene bevolking gebeurt, zoals eerder aangegeven, veelal aan de hand van algemene vragen. Er is maar weinig onderzoek verricht waarin op systematische wijze zowel werd gevraagd naar het voorkomen van inslaap- en doorslaapproblemen en naar te vroeg wakker worden, als naar problemen met slaperigheid overdag. Kales et al. (1980) raden aan om bij het inventariseren van slaapklachten de 24 uurs slaap-waak-cyclus als uitgangspunt te nemen. Waken en slapen staan immers niet los van elkaar; zo kunnen er, als gevolg van het regelmatig overdag dutjes doen,'s nachts slaapproblemen ontstaan. Een aantal richtlijnen om slaapklachten zo nauwkeurig mogelijk te meten zijn: (1) definieer het specifieke slaapprobleem; bijv. gaat het hier om vermoeidheid, uitputting, of slaperigheid; (2) ga na wat de mogelijke oorzakelijke problemen zijn; bijv. is slaperigheid overdag een op zich zelfstaande klacht, of het gevolg van insomnia; (3) de feitelijke slaapduur krijgt pas dan betekenis, wanneer deze in verband kan worden gebracht met mogelijke insomniaklachten.

Voorbeelden van gebruikelijke vragen bij slaaponderzoek zijn: "Hoeveel uren slaapt U gemiddeld?" of "Heeft U wel eens slaapproblemen?" (Wingard et al., 1983), dan wel "Hoeveel uur slaapt $U$ gemiddeld 's nachts?" of "Heeft U last van insomnia?" (Kripke et al., 1979). Andere vragen die in slaaponderzoek gesteld werden zijn: "Sliep u in het afgelopen jaar over het algemeen slecht?", "Staat U 's nachts vaak op?", "Voelde U zich 's morgens uitgerust bij het opstaan?", of "Deed U overdag vaker een dutje?". Een laatste voorbeeld betreft het onderzoek van Partinen (1984), waarbij werd gevraagd naar het voorkomen van insomniaklachten in de algemene bevolking. Hierbij werd een duidelijk onderscheid gemaakt tussen problemen met inslapen en doorslapen en problemen met 's morgens te vroeg wakker worden. Deze vragen werden beantwoord middels een vijfpuntsschaal, terwijl in de vorige studies meestal "ja-nee", of "vaak-soms-nooit" antwoordcategoriëen werden gebruikt.

In deze vragenlijsten werd in het algemeen niet uitvoerig ingegaan op het voorkomen van problemen met het functioneren overdag m.u.v. de studie van Zomer et al. (1985). Deze auteurs brachten niet alleen problemen met het dagelijks functioneren in kaart, maar ook die met de nachtelijke slaap, omdat 's nachts slecht slapen het voorkomen van slaperigheid of vermoeidheid overdag kan verklaren. Hun vragenlijst, de "Mini Sleep Questionnaire", bestaat uit de volgende zeven vragen (tabel 2.4.).

Deze vragen kunnen middels een zevenpuntsschaal worden beantwoord.

In het verleden zijn een aantal slaapklachtenlijsten ontwikkeld waarmee men slaapklachten in de algemene bevolking kan inventariseren. In Nederland heeft De Diana (1976) twee van dergelijke schalen opgesteld. Middels de specifieke slaapkwaliteitsschaal, bestaande uit 11 vragen, is het mogelijk slaapklachten in de afgelopen nacht vast te leggen, terwijl men met de 10 vragen tellende algemene 
slaapkwaliteitsschaal een algemene indruk over de slaap verkrijgt.

Tabel 2.4. De Mini Sleep questionnaire

1. "Do you fall asleep during the day, particularly when you are not busy?"

2. "Do you suffer from morning fatigue?"

3. "Do you snore during sleep?"

4. "Do you occasionally wake up during sleep?"

5. "Do you suffer from headaches on wakening?"

6. "Do you suffer from chronic unexplained fatigue?"

7. "Do you sleep restlessly?"

De meest uitgebreide vragenlijsten waarmee men slaapklachten kan vaststellen zijn die welke in Amerikaanse slaapklinieken worden gebruikt (Miles, 1979). Zo bestaat de "Sleep Questionnaire and Assessment of Wakefulness (SQAW)" van Miles uit 858 vragen. Mede gezien dit aantal is deze lijst niet geschikt voor populatieonderzoek. Bovendien wordt er naar klachten gevraagd die in de algemene bevolking maar zelden voorkomen. Anderzijds werd er in de V.S. onlangs een korte vragenlijst gepubliceerd (Jenkins, 1988), waarmee het mogelijk is een idee te krijgen over het voorkomen van slaapklachten bij klinisch onderzoek, aan de hand van de volgende vier vragen (tabel 2.5.).

Tabel 2.5. De oorspronkelijke slaapklachtenlijst van Jenkins

"How often in the past month did you $\langle\ldots\rangle$ ":

1. Have trouble falling asleep?

2. Wake up several times per night?

3. Have trouble staying asleep (including. waking far too early)?

4. Wake up after your usual amount of sleep feeling tired and worn out?

Men kan hierbij kiezen uit een zestal antwoordcategoriëen: (1) helemaal niet, (2) I-3 dagen, (3) 4-7 dagen, (4) 8-14 dagen, (5) 15-21 dagen, en (6) 22-31 dagen.

Om enerzijds slaapklachten op systematische wijze te kunnen inventariseren en anderzijds een duidelijk onderscheid te maken tussen klachten van voorbijgaande duur (minder dan 3 weken) en chronische aard (meer dan 3 weken) (Coleman 1983; Parkes, 1985), ontwikkelden Van Diest et al. (1989, 1990) een vragenlijst die al deze eigenschappen vertoont. Bij deze "Slaap-Waak Ervaring Lijst (SWEL)" is gebruik gemaakt van een aantal eerder genoemde vragenlijsten waaronder die van De Diana (1976), Lavie (1981), Miles (1982) en Zomer et al. (1985). Met uitzondering van "slaperigheid overdag" zijn er vragen opgenomen over zowel de. 
ernst van de klacht als over de frequentie. Bij "slaperigheid overdag", zijn alleen vragen opgenomen over de frequentie. Van een aselekte steekproef van 1500 mannen van middelbare leeftijd uit Maastricht vulden uiteindelijk 451 (30\%) deze vragenlijst volledig in. Als voornaamste resultaten kwamen naar voren dat $19.7 \%$ aangaf problemen te hebben met de slaap en/of het functioneren overdag; $10 \%$ insomniaklachten rapporteerde, en $6.4 \%$ klaagde over slaperigheid overdag. Van alle deelnemers werden 24 mannen met en 18 zonder slaapklachten uitgenodigd voor een nader klinisch interview. Door een vergelijking van de SWEL-gegevens met die van het interview werd de validiteit van de SWEL onderzocht. Daaruit blijkt dat de SWEL als screeningsinstrument gemiddeld tot hoog scoort bij het opsporen van slaapklachten, en gemiddeld als diagnostisch- en prognostisch instrument (van Diest, et al., 1989) (tabel 2.6).

Tabel 2.6. Kappa screening, Kappa diagnose, Kappa prognose (Bron: van Diest et al., 1989)

\begin{tabular}{llll}
\hline & Kappa screening & Kappa diagnose & Kappa prognose \\
Inslapen & $74.1 \%$ & $57.2 \%$ & $64.6 \%$ \\
doorslapen & $52.3 \%$ & $52.8 \%$ & $52.5 \%$ \\
te vroeg wakker & $70.5 \%$ & $74.4 \%$ & $72.5 \%$ \\
moeilijk wakker & - & - & - \\
moe opstaan & $81.9 \%$ & $74.5 \%$ & $78.0 \%$ \\
slaperigh. overdag. & $90.3 \%$ & $51.1 \%$ & $65.3 \%$ \\
\hline
\end{tabular}

\section{Samenvatting}

Er zijn in de loop van de jaren een aantal vragenlijsten ontwikkeld waarmee het mogelijk is slaapklachten te meten. Deze vragenlijsten werden echter tot nu toe niet gebruikt om de relatie tussen slaapklachten en het hartinfarct te bestuderen. In het onderhavige onderzoek zal dit wel gebeuren. Allereerst zel op globale wijze de slaapduur worden bepaald. Met de vragenlijst van Jenkins wordt een algemene indruk verkregen over het voorkomen van slaapklachten bij hartinfarctpatiënten en ziekenhuiscontroles in de periode voorafgaande aan de ziekenhuisopname. Middels de SWEL zullen de eigenlijke vraagstellingen en hypothesen worden onderzocht. Zoals werd vermeld is het mogelijk met deze vragenlijst chronische slaapklachten te meten, waarbij zowel gelet wordt op de intensiteit als de frequentie. 


\subsection{SLAAPAPNEU}

De interesse in slaapapneu, d.w.z. het stoppen van de ademhaling tijdens de slaap, is de afgelopen jaren sterk toegenomen (Guilleminault, 1976, 1983; Lavie 1983; Siegrist, 1987). Bij 3.5\% van de mannelijke populatie in de leeftijd tussen de 40 en 60 jaar komt slaapapneu voor, bij vrouwen aanzienlijk minder (Vollmer, 1987). Onderzoek heeft uitgewezen dat er een mogelijke samenhang bestaat tussen slaapapneu en hart- en vaatziekten (Peter et al., 1985; Siegrist, 1987(a); Koskenvuo, 1987). Een verklaring hiervoor kan zijn dat apneu-aanvallen tot bradydycardieen leiden en er tegelijkertijd sprake is van een dramatische stijging van de bloeddruk (Vollmer, 1987). Slaapapneu is het hevigst tijdens REM-slaap, wanneer de ademhalingsspieren het meest ontspannen zijn. Tijdens de normale slaap is er sprake van een langzaam hartritme. Dit ritme neemt iets toe tijdens de REM slaap. Bij slaapapneu is er sprake van bradyaritmie (Deedwania et al., 1979). Dit kan bij personen waarbij er nog geen sprake is van manifest hartlijden de kans hierop vergroten.

Het onderzoek naar slaapapneu gebeurt in het slaaplaboratorium of de kliniek. Middels dit onderzoek is het mogelijk slaapapneu vast te stellen en om welke vormen het hierbij gaat: (1) Obstructieve slaapapneu t.g.v een obstructie van de bovenste luchtpijp; (2) Centrale slaapapneu t.g.v. centrale veranderingen van de ademhaling; en (3) gemengde slaapapneu, waarbij sprake is van obstructie en centrale veranderingen (Deedwania et al., 1979). Daar onderzoek in het laboratorium erg arbeidsintensief is en het ook van de patiënt het nodige vraagt, tracht men ook om middels inventarisatie van klachten m.b.v. vragenlijsten slaapapneu te identificeren. Siegrist (1987) heeft een dergelijke vragenlijst ontwikkeld. De centrale thema's in deze vragenlijst zijn: (1) het voorkomen van slaapaanvallen en slaperigheid overdag, alsmede de daarmee gepaard gaande ervaringen bij het wakker worden; (2) beschrijvingen van de nachtelijke slaap en de wijze van het 's morgens wakker worden en opstaan; (3) de aanwezigheid van lichamelijke problemen die bij slaapklachten kunnen voorkomen; en (4) informatie over de slaap verkregen van derden, bijv. in verband met het voorkomen van nachtelijke ademstilstand.

Slaapapneu gaat o.a. gepaard met hypersomnia en chronische insomnia. Vooral wanneer er sprake is van obstructieve slaapapneu klaagt men over hypersomnia. Slaapapneu wordt dan ook als de belangrijkste oorzaak van hypersomnia beschouwd (Coleman et al., 1980). Bij centrale slaapapneu wordt vooral geklaagd over insomnia.

Per nacht komen ongeveer honderd aanvallen voor. De patiënt ontwaakt dan of de slaap wordt lichter. Stadium 3 en 4, d.w.z. de diepe slaap, komt dan ook weinig voor bij de apneupatiënt. Slaperigheid overdag kan hier een consequentie van zijn (Vollmer, 1987). 
Wanneer de apneupatiënt klaagt over een slechte slaap dan komt dit meestal doordat hij doorslaapproblemen heeft. Partners geven eveneens aan, dat de apneu patiënt meestal 's nachts hevig snurkt. Het gaat hierbij orn periodes waarin het snurken (hard en hevig) afgewisseld wordt met periodes waarin de patiënt niet ademt (apneu). Er wordt hierbij ook geklaagd over kortademigheid (Kapuniai et al., 1989). Verder blijkt de apneupatiënt erg onrustig te slapen: zij bewegen erg veel (Williams et al., 1988).

Zoals al eerder is aangegeven klagen apneupatiënten voornamelijk over slaperigheid overdag. Williams et al. (1988) voegen hier vermoeidheid overdag aan toe. Tevens klagen apneu-atiënten over geheugenverlies, verwardheid in de ochtend, en hoofdpijn bij het wakker worden. Ook kan er sprake zijn van persoonlijkheidsveranderingen, in de vorm van jaloezie, achterdocht, angst en depressie (Williams et al., 1988).

\subsection{SAMENVATTING}

In het onderhavige onderzoek wordt rekening gehouden met de kritiek op het onderzoek naar het voorkomen van slaapklachten in de algemene bevolking of bij hartpatiënten. Op grond van de literatuurbevindingen zullen problemen met de nachtelijke slaap en met het functioneren overdag worden uitgewerkt. Insomnia en hypersomnia zijn zowel de meest voorkomende slaapklachten in de algemene bevolking als klachten die veelvuldig worden gerapporteerd in relatie met het hartinfarct.

Allereerst zal in het onderhavige onderzoek onderzocht worden of er een samenhang is tussen slaapduur en hart- en vaatziekten. Onderzoek heeft uitgewezen dat er aanwijzingen zijn voor dit verband. Aan de hand van de slaapklachtenlijst van Jenkins, die het voorkomen van slaapklachten meet, wordt vervolgens nagegaan of hartinfarctpatiënten wat dat betreft van de ziekenhuiscontroles verschillen. De slaapklachten zullen vervolgens systematisch worden geinventariseerd door gebruik te maken van de SWEL. Het gaat hierbij om het voorkomen van chronische slaapklachten. Tevens wordt er, uitgaande van de 24-uurs slaap-waak cyclus, gekeken of er respectievelijk insomnia en/of hypersomnia klachten voorkomen.

In het onderhavige onderzoek zal eveneens worden nagegaan of er hetzij somatische, hetzij mentale factoren zijn die de samenhang tussen slaapklachten en hart- en vaatziekten veroorzaken. Slaapapneu blijkt in verschillende studies deze samenhang te verklaren. Door een inventarisatie van de bij slaapapneu behorende klachten tracht het onderzoek tenslotte, mogelijk enig inzicht te verkrijgen in de onderliggende mechanismen. 


\section{HOOFDSTUK 3}

\section{HYPOTHESEN, EXPLORATIES EN METHODEN}

\subsection{VRAAGSTELLING \& HYPOTHESEN}

De centrale vraag van dit onderzoek is of mannen in de periode voor het eerste hartinfarct slechter slapen en zo ja om welke slaapklachten het dan gaat: slaapduur, problemen met het inslapen, doorslapen m.b.t. het wakker worden of vermoeid of slaperig zijn overdag. Uitgaande van de 24 uurs slaap-waak cyclus wordt er nagegaan of het voornamelijk insomnia en/of hypersomnia klachten zijn. Indien de exploratie van de specifieke slaapproblemen aangeeft dat iñfarctpatiënten en controles in een of meerdere gevallen significant van elkaar verschillen, wordt verder nagegaan wat de mogelijke oorzaken daarvan zijn, waarbij dan met name wordt gelet op somatische en/of mentale factoren en slaapapneu.

Bepaalde slaapproblemen hebben een sterke associatie met vitale uitputting (VU). Op het moment dat dit onderzoek startte was de definitieve omschrijving en de meting van dit concept niet gereed. Het was de vraag of VU een gevolg is van een slaapprobleem of dat bepaalde slaapproblemen als een onderdeel van dit syndroom gezien moesten worden. Als eerste stap werd nagegaan of VU tot de risicoindicatoren van het hartinfarct behoort. Als tweede stap werd nagegaan of slaapklachten nog differentiëren tussen cases en controles bij controlle op VU. Wanneer zou blijken dat slaapklachten hun discriminerend vermogen verliezen wanneer gecontroleerd wordt voor VU, dan leidt dit tot de conclusie dat deze slaapklachten een risicoindicator zijn omdat zij deel uitmaken van een groter syndroom.

Tenslotte zal aandacht besteed worden aan de begrippen vigor en immersion. Deze concepten zijn recent ontwikkeld door Siegrist en lijken verband te hebben met zowel VU als slaapklachten. Wij wilden hun onderlinge samenhang nagaan.

Andere variabelen, die in de literatuur als risicofactoren voor het hartinfarct zijn genoemd, worden in dit onderzoek als mogelijke "confounders opgenomen, teneinde er voor te kunnen controleren. Het gaat hierbij om: leeftijd, 
roken, AP,"life events", en Type A gedrag. Tevens wordt er in dit kader gevraagd naar koffie- en alcoholgebruik en naar het vóórkomen van pijn.

\subsection{METHODE: "CASE-CONTROL" ONDERZOEK}

Zoals eerder aangeduid, werd dit onderzoek opgezet als een "case-control"-studie, waarin mannen, in leeftijd variërend van 35 - 65 jaar, die waren opgenomen vanwege een eerste, klinisch gedocumenteerd hartinfarct, werden vergeleken met even oude mannen, die terzelfdertijd in hetzelfde ziekenhuis voor andere aandoeningen waren opgenomen. Getracht werd om bij iedere infarctpatiënt een controle van ongeveer gelijke leeftijd te vinden, om een mogelijk leeftijdseffect m.b.t. de samenhang tussen slaapproblemen en het hartinfarct uit te kunnen sluiten.

\section{A. Voor- en nadelen van "case-control" onderzoek}

De keuze voor een "case-control" onderzoek berust veelal op practische overwegingen: longitudinaal onderzoek is doorgaans tijdrovend en duur, waardoor het rendement veelal laag is (Kleinbaum et al., 1982). Omdat "follow-up"onderzoek de standaard vormde, werd "case-control"-onderzoek in het verleden als een minder valide vorm van epidemiologisch onderzoek gezien. Bij het uitvoeren van "case-control"-onderzoek moest daarom aan enkele voorwaarden zijn voldaan. Allereerst behoren zowel "cases" als controles uit de algemene populatie te komen op voorwaarde van representativiteit. Daarnaast moeten de controles zoveel mogelijk identiek zijn aan de cases, de voorwaarde van vergelijkbaarheid, en idealiter slechts verschillen m.b.t. de onderzochte ziekte (Rothman, 1986). Uitsluitend wanneer er sprake was van een zeldzame ziekte konden de gegevens verkregen uit "case-control"-onderzoek op identieke wijze worden verwerkt als die uit longitudinaal onderzoek (Cornfield, 1951).

Bovengenoemde uitgangspunten zijn echter verouderd. In de afgelopen jaren is er m.b.t. de methodologische benadering van "case-control"-onderzoek, en de voorwaarden die eraan gesteld moeten worden, het nodige veranderd. Er is met name meer aandacht besteed aan het formuleren van criteria waaraan de controlegroep moet voldoen.

\section{A.1. Criteria voor controles}

Afwijkend van de tot op dat moment heersende mening, zoals verwoord door MacMahon \& Pugh (1970) stellen Lilienfeld \& Lilienfeld (1980) dat controles geen representatieve steekproef behoeven te zijn uit de algemene populatie. Zij moeten daarentegen wel bestaan uit personen die identiek zijn aan de 
"cases", behalve m.b.t. de factor die wordt onderzocht, in deze studie dus het MI. "Cases" zijn daarmee representatief voor alle personen met en controles voor al diegenen zonder de ziekte. De verdeling van de te onderzoeken variabelen in de steekproef, bijv. slaapproblemen, moet overeenkomen met die in de algemene populatie.

Schlesselman (1982) gaat hierin nog een stap verder. Controles moeten niet alleen vrij zijn van de onderzochte ziekte, maar moeten eveneens bloot kunnen staan aan de "exposure"-variabele. Een probleem hierbij is echter dat wanneer het onderzoek zich richt op het selecteren van een bepaalde controlegroep ook de verdeling van de "exposure"-variabele kan worden beînvloed. In dit onderzoek betekent dit dat door ziekenhuiscontroles te selecteren de kans groter is dat slaapklachten in deze groep vaker voorkomen dan wanneer voor "gezonde" controles zou zijn gekozen. Wanneer uit onderzoek komt vast te staan dat door de keuze voor bepaalde controles deze verdeling veranderd is, wordt hiervoor veelal achteraf gecorrigeerd. Door deze correctie verandert echter de "exposure odds" in de steekproef op grond van een selectie, die gebaseerd is op de gegevens van het onderzoek zelf. Er vindt daarmee geen juiste weergave plaats van de aanwezigheid van de "exposure" variabele in de populatie. Het achteraf selecteren van controles, omdat er op grond van de resultaten een relatie bestaat tussen de "exposure" variabele en enkele controles, wordt echter vanwege bovengenoemde reden afgeraden (Pearce \& Checkoway, 1988).

Volgens Miettinen (1985) vormeñ controles ook een steekproef uit de "source population", d.w.z. de populatie waaruit de "cases" voortkomen. De steekproef moet zo genomen worden dat deze een goede weergave vormt van de verdeling van de "exposure" variabele in de "source population". Informatie over de juiste steekproef kan verkregen worden aan de hand van theoretische kennis.

De specificatie van de "study base", d.w.z. de feitelijke populatie waaruit de te onderzoeken personen voortkomen, is niet inherent aan het onderzoek, maar veelal een specifieke keuze van de onderzoeker (Miettinen, 1985). De "study base", waaruit uiteindelijk een steekproef wordt genomen, wordt bepaald door de selectiecriteria, de mogelijke "confounders", en de grootte van de steekproef. Miettinen (1985) raadt daarbij aan om ziekenhuiscontroles te gebruiken, niet alleen om practische redenen, zoals gemakkelijke bereikbaarheid, maar vooral omdat de voorgeschiedenis veelal hetzelfde is. Er wordt in "casecontrol"-onderzoek namelijk uitgegaan van het verzamelen van gegevens over de periode voorafgaande aan de ziekenhuisopname.

Rothman (1986), tenslotte, hanteert m.b.t. de keuze en definiëring van een controlegroep een andere benadering. Volgens hem is het onmogelijk mensen te verzamelen die representatief zijn voor de gehele populatie. Het is daarom beter om personen te verzamelen die in principe een "case" kunnen worden. De controlegroep vertegenwoordigt dan daarmee een schatting van de verdeling 
van de "exposure" variabele in de populatie waaruit de "cases" komen. Iedere "case" had dus een controle kunnen zijn tot het moment waarop deze ziek werd. Volgens Rothman vormen controles een groep van personen die, wanneer ze de ziekte zouden krijgen welke de afhankelijke variabele vormt in "case-control"onderzoek, op dezelfde wijze geselecteerd zouden worden als "cases". De controles vertegenwoordigen dus de populatie waaruit de "cases" komen.

\section{B. Waarom ziekenhuiscontroles?}

De keuze voor ziekenhuiscontroles heeft een aantal voordelen boven die van "gezonde" controles. Allereerst is de bereidheid tot deelname aan het onderzoek en de kwaliteit van de verkregen informatie veelal vergelijkbaar met die van de "cases". Bovendien is het goed mogelijk beiden op dezelfde wijze te benaderen; de uitval is meestal gering. Verder is het referentiepunt voor beide groepen grotendeels identiek, omdat wordt uitgegaan van de periode voorafgaande aan de ziekenhuisopname. Een ander argument voor de keuze voor ziekenhuiscontroles is dat de mogelijke "recall bias" bij "cases" en controles veelal gelijk is (Sackett, 1979). Een controlegroep, die bestaat uit personen met een andere ziekte dan die van de cases, bevat een meer valide schatting van de verdeling van de "exposure" variabele in de onderzoekspopulatie dan een willekeurige controlegroep uit de algemene populatie. De onderzoekspopulatie is bij de keuze voor "gezonde" controles zonder specifieke criteria immers niet duidelijk gedefinieerd (Pearce \& Checkoway, 1988).

De belangrijkste selectiecriteria die doorgaans bij de keuze voor ziekenhuiscontroles worden gehanteerd, zijn:

1. De ziekte waarvoor men is opgenomen mag, op grond van theoretische verwachtingen, niet samenhangen met de "exposure" variabele (Jick \& Vessey, 1978; Axelson et al., 1982; Wang \& Miettinen, 1982; Axelson, 1985; Miettinen, 1985; Smith et al., 1988). Dat de ziekte waarvoor men is opgenomen kan samenhangen met de "exposure" variabele, vormt echter weer een nadeel;

2. Hierbij kan het volgende probleem ontstaan: Het kan voorkomen dat er geen zekerheid bestaat over een samenhang, negatief dan wel positief, tussen de "exposure" variabele en de ziekte waarvoor de controle is opgenomen. Geadviseerd wordt in zo'n geval personen te nemen die om uiteenlopende redenen zijn opgenomen (Jick \& Vessey, 1978; Ibrahim, 1979; Axelson et al., 1982; Axelson, 1985; Smith et al., 1988);

3. De controles moeten de verdeling weergeven van de "exposure" variabele in de populatie, waaruit de "cases" komen.

In het onderhavige "case-control" onderzoek is daarom gekozen voor ziekenhuiscontroles. Bij het selecteren van deze groep is zoveel mogelijk rekening 
gehouden met het feit dat de ziekte waarvoor de patiênt was opgenomen, niet samen ging met de belangrijkste onderzoeksvariabelen. Bovendien werd een controlegroep van uiteenlopende samenstelling gevormd.

\subsection{VALIDITEITSPROBLEMEN}

Validiteitsproblemen die zich in "case-control"-onderzoek voordoen, kunnen een gevolg zijn van informatie bias, selectie bias, en "confounding" (Kleinbaum et al., 1982), alsmede van "recall" bias (Raphael, 1987).

\section{A.1. Informatie bias \& "Recall" bias}

$\mathrm{Er}$ is sprake van informatie bias wanneer als gevolg van meetfouten of misclassificatie van personen de geschatte relatieve risico's onjuist zijn. Oorzaken hiervoor kunnen zijn: het gebruiken van niet-valide meetinstrumenten, onjuiste diagnostische en/of uitsluitingscriteria, en/of andere onvolledigheden bij het verzamelen van de gegevens. Schlesselman (1982) noemt in dit kader tevens onjuiste informatie, omdat de geïnterviewde onjuiste en/of onvolledige informatie verstrekt t.g.v. sociaal wenselijk gedrag, een slecht geheugen, of verwarring. Hij rangschikt hieronder eveneens de bias die veroorzaakt kan worden door de interviewer zelf. Door de wijze waarop deze zijn vragen stelt, kan al dan niet bewust de beantwoording ervan worden beïnvloed.

Er wordt gesproken van "recall" bias wanneer "cases" en controles onderling zodanig verschillen m.b.t. het rapporteren van gebeurtenissen die kunnen samenhangen met de ziekte, dat men ten onrechte de conclusie trekt dat de onderzochte "exposure" variabele het risico m.b.t. de afhankelijke variabele verhoogt, terwijl dit in werkelijkheid niet het geval is. De alternatieve hypothese wordt dus niet verworpen (fout van de tweede soort). "Recall" bias heeft niets te maken met vergeten (alpha foutt). Gebeurtenissen worden niet genoemd omdat men denkt dat deze niet kunnen samenhangen met de ziekte. Volgens Raphael (1987) zijn er een aantal mogelijkheden om "recall" bias te meten, bijvoorbeeld door de nieuwe gegevens te vergelijken met bestaande data van de patiënt.

\section{A.2. Selectie bias}

Men spreekt van selectie bias wanneer als gevolg van de wijze waarop de personen werden geselecteerd de effectmeting onjuist is. Oorzaken hiervan kunnen zijn: de onjuiste keuze van een controlegroep of "study base", en/of wanneer de ziekte die men onderzoekt varieert met de "exposure" variabele. De ziekte wordt dan eerder gediagnosteerd bij mensen waarbij ook deze variabele 
aanwezig is. Selectie bias is ook wel "detection bias" (Feinstein, 1977) of "unmeasuring bias" (Sackett, 1979) genoemd. Bij de selectie van "cases" en controles moet men ervan uitgaan, dat zowel de "exposed" "cases" of controles als de "unexposed", gelijke kansen hebben om geselecteerd te worden. Dit kan goed wanneer men kiest voor ziekenhuiscontroles met verschillende primaire diagnoses (Mantel \& Haenszel, 1959, Jick \& Vessey, 1978). Hierdoor wordt voorkomen dat er geen relatie tussen de effect-variabele en de ziekte wordt gevonden, terwijl deze toch werkelijk bestaat, of dat er een relatie wordt aangetoond terwijl deze in werkelijkheid niet aanwezig is.

\section{A.3. "Confounding"}

Er is tenslotte sprake van "confounding" wanneer de relatie tussen de "exposure" variabele en de afhankelijke variabele wordt verklaard door een derde variabele, die met beide samenhangt. Een goed voorbeeld hiervan is roken, dat zowel samenhangt met slaapproblemen als het hartinfarct. Men kan hiervoor echter achteraf statistisch controleren, hetgeen niet mogelijk is bij de eerder genoemde validiteitsproblemen.

\section{B. Validiteitsproblemen in het onderhavige "case-control"-onderzoek}

In dit onderzoek is met al deze vormen van bias zo goed mogelijk rekening gehouden.

Bij de informatie bias geschiedde dit door het gebruik van gestandaardiseerde vragenlijsten.

Omdat zowel "cases" als ziekenhuiscontroles zich waarschijnlijk zullen afvragen waarom zij de ziekte hebben gekregen, zal het optreden van recall bias gelijk zijn bij "cases" en controles (Sackett, 1979). Interviewer bias werd uitgesloten door de vragenlijsten door de patiënten zelf te laten invullen. Tevens werd er voor gezorgd, dat de periode tussen ontslag uit het ziekenhuis en het invullen van de vragenlijsten voor beide groepen zo veel mogelijk gelijk was.

Selectie bias werd voorkomen door de selectie van "cases" en controles te laten verrichten door derden in het ziekenhuis, die niet vertrouwd waren met de eigenlijke vraagstelling. $\mathrm{Bij}$ hen was slechts bekend dat middels vragenlijsten de periode voorafgaande aan de ziekenhuisopname werd onderzocht.

Ook kan er worden uitgesloten dat er sprake is van "Berkson's" bias, d.w.z. dat het aanwezig zijn van de "exposure" variabele betekent dat personen eerder worden opgenomen en daardoor eerder worden geselecteerd voor het onderzoek. Ziektecategorieën die sterk samenhangen met de "exposure" variabele werden daarom uitgesloten. 
Tenslotte wordt "confounding" aangepakt door een aantal mogelijke "confounders" in het onderzoek op te nemen, zodat hiervoor later in de statistische analyses kan worden gecontroleerd.

\subsection{DEFINITIES EN SELECTIE VAN "CASES" EN CONTROLES}

\section{A. "Cases"}

"Cases" zijn mannen tussen de 35 en 65 jaar die vanwege een eerste gedocumenteerd myocardinfarct in een ziekenhuis zijn opgenomen. Mannen met een herinfarct worden uit het onderzoek gelaten. Door het eerder meegemaakt hebben van een hartinfarct wordt het immers onduidelijk hoe de resultaten bij deze personen geinterpreteerd dienen te worden. De beantwoording van de vragenlijsten staat dan mogelijk meer in het teken van verwerking van en omgaan met het eerste hartinfarct dan met het recente. Er is bovendien gekozen voor dit uitsluitingscriterium omdat, vanwege de te verwachten kleine aantallen, het niet. goed mogelijk zou zijn hiervoor achteraf te controleren.

Het selecteren van de "cases" gebeurde op grond van de klinische anamnese door de behandelend specialist. Er is gekozen voor een leeftijdsgrens tot 65 jaar omdat daarboven risicofactoren minder goed of in het geheel niet meer discrimineren (Miettinen, 1985; Williams, 1987).

Aan de hand van een power berekening over gegevens, verzameld in een vooronderzoek over slaapklachten in de periode voorafgaande aan het hartinfarct, werd bepaald hoeveel "cases" er tenminste nodig zouden zijn (Schlesselman, 1974). Uitgaande van $\alpha=0.05, \beta=0.10, p=0.30$, en een "odds ratio" van 3.0 , bedroeg het aantal "cases" minimaal 75 ; hierbij is uitgegaan van een gelijk aantal cases en controles. Deze p-waarde is de prevalentie van de expositie in de populatie. Omdat bij het uitvoeren van gestratificeerde analyses echter een te. kleine celvulling zou kunnen ontstaan, is uiteindelijk gekozen voor een grotere controle groep, d.w.z. 1,5 keer zo groot. Het aantal "cases" dat middels een dergelijke berekening wordt bepaald, is echter tamelijk arbitrair, omdat dit aantal afhangt van de gekozen $\beta$-waarde, p-waarde en "odds ratio" (Rothman, 1986). Omdat er echter geen andere en betere richtlijnen voorhanden zijn, is er toch voor deze methode gekozen om het aantal "cases" te bepalen.

\section{B. Controles}

Ten aanzien van de controlegroep werd er uitgegaan van de eerder beschreven ideeên van Schlesselman (1982) en Miettinen (1985) gekozen voor zie- 
kenhuiscontroles. Evenals bij de "cases" kwamen alleen mannen tussen de 35 en 65 jaar voor deelname in aanmerking.

Aanvankelijk zouden enkel acuut opgenomen patiënten bij het onderzoek worden betrokken, omdat een opname voor een hartinfarct een acuut karakter heeft. Vanwege het feit echter dat gaande het onderzoek slechts een gering percentage, ongeveer $15 \%$, daadwerkelijk acuut wordt opgenomen, werd dit selectiecriterium verruimd. Uiteindelijk deden daarmee controles mee die zowel acuut als voor een operatieve ingreep waren opgenomen. In principe kwamen alle mannen in de betreffende leeftijdsgroep in aanmerking indien de ziekte waarvoor men werd opgenomen, niet samenhing met de "exposure" variabele. Mannen, opgenomen vanwege een chronische maligne pijnlijke aandoening, worden dus buiten het onderzoek gelaten, evenals mannen met een reeds bekende hartziekte.

\subsection{PROCEDURES}

Eenmaal in de week bezocht de onderzoekster, of een medewerker, de afdelingen cardiologie en algemene chirurgie van de ziekenhuizen te Maastricht, Kerkrade, en Roermond.

\section{A.1. "Cases"}

De hartinfarct-patiënten werden als volgt verzameld. Tijdens de wekelijkse patiëntenbespreking werden, aan de hand van hun medische status, alle hartpatiënten geselecteerd die aan eerder genoemde selectiecriteria voldeden. Daarna werden deze patiënten nog tijdens hun opname bezocht. De bedoeling en de procedure van het onderzoek werden uitgelegd en wanneer de patiënt toestemde werden hem na ontslag uit het ziekenhuis de vragenlijsten toegestuurd. Deze werden dus thuis ingevuld, maar hadden betrekking op de periode voorafgaande aan de ziekenhuisopname. Waar mogelijk werd twee weken later een telefonische afspraak gemaakt voor het ophalen van de vragenlijsten. Tijdens dit huisbezoek werd nagegaan of er problemen waren gerezen met het invullen van de vragenlijsten en werd het Gestructureerde Interview ter bepaling van Type A gedrag afgenomen. Indien een huisbezoek niet mogelijk was, werden de vragenlijsten per post geretourneerd.

\section{A.2. Onderzoekspopulatie, hartinfarct-patiënten}

In totaal werden de gegevens van 79 MI-patiënten geanalyseerd, zoals weergegeven in tabel 3.1 . Om aan dit aantal te komen, werden 100 patiënten 
benaderd: 45 patiënten ( $45 \%$ ) uit het AZM te Maastricht, en respectievelijk 27 $(27 \%)$ en $28(28 \%)$ patiênten uit de ziekenhuizen van Kerkrade en Roermond. Van deze 79 MI-patiēnten vulden 11 patiēnten (14\%) alleen de vragenlijsten in. Omdat huisbezoek bij hen op korte termijn niet mogelijk was, werd bij hen geen Gestructureerd Interview ter bepaling van Type A gedrag afgenomen. Met uitzondering van de $\mathrm{A} / \mathrm{B}$ typologie werden echter alle overige variabelen ook in deze groep gemeten.

Tabel 3.1. Werving van hartinfarctpatiënten en ziekenhuiscontroles

MYOCARDINFARCT

Totaal aantal benaderde personen

Weigeringen

Vragenlijsten onvolledig ingevuld

Heropname, complicaties, overleden na ontslag

Oud infarct

Chronische pijnlijke aandoening

Aantal personen in onderzoek
100

5

3

4

9

$-$

79

\section{CONTROLES}

194

36

1

5

20

132

\section{B.1. Controles}

Controles werden op dezelfde marier verzameld als "cases" via de afdelingen algemene chirurgie van de betreffende ziekenhuizen. Iñ tegenstelling tot bij de "cases" was het echter niet mogelijk inzage te krijgen in hun medische status. In plaats daarvan gaven de betreffende afdelingen de namen door van de patiënten, die volgens de contactpersonen in aanmerking kwamen voor het onderzoek. Daardoor kon geen informatie worden verkregen over een mogelijk voorafgaande ziektegeschiedenis die tot uitsluiting zou hebben geleid, en kwam het soms voor dat patiënten achteraf toch aan bovengenoemde uitsluitingscriteria voldeden. Deze werden dan alsnog buiten het onderzoek gelaten. Evenals de "cases" werden de controles in het ziekenhuis benaderd, werd hen het onderzoek en de procedure uitgelegd, en werden na verleende toestemming de vragenlijsten toegestuurd. Tesamen met deze vragenlijsten werd een brief gezonden die een toelichting op het onderzoek inhield (zie bijlage 1). Tenslotte werden 
ook de ziekenhuiscontroles thuis bezocht volgens dezelfde procedure als bij de "cases".

\section{B.2. Onderzoekspopulatie, ziekenhuiscontroles}

Zoals tabel 3.1. aangeeft, werden de gegevens van in totaal 132 ziekenhuiscontroles geanalyseerd. Om dit aantal te bereiken, werden 194 controles benaderd: 55 patiënten ( $28 \%$ ) uit het AZM te Maastricht en respectievelijk 67 (35\%) en 72 patiënten ( $37 \%$ ) uit de ziekenhuizen van Kerkrade en Roermond. Hiervan hadden 36 patiënten geen interesse in deelname; 20 patiẻnten leden aan een chronische pijnlijke aandoening, waardoor zij alsnog uit het onderzoek werden verwijderd. Van de controlegroep konden 18 patiënten $(14 \%)$ niet persoonlijk thuis benaderd worden. Ook van hen zijn daarom geen gegevens over de A/B typologie bekend.

De meeste patiënten waren opgenomen voor de behandeling van aandoeningen aan maag, darm= en galwegen $(\mathrm{N}=39)$, van een liesbreuk $(\mathrm{N}=22)$, van aandoeningen aan het bewegingsapparaat $(\mathrm{N}=17)$, van claudicatio $(\mathrm{N}=14)$, of een (bedrijfs)ongeval, in het bijzonder fracturen $(N=13)$. Zoals aangegeven werd bij de selectie van de ziekenhuiscontroles uitgegaan van twee criteria, namelijk, niet lijdende aan een hartziekte en niet opgenomen zijn vanwege een chronische, maligne pijnlijke aandoening. Bij inspectie van de data bleek echter dat controles significant vaker klaagden over pijn en lichamelijk ongemak in de drie maanden voorafgaande aan hun ziekenhuisopname dan de MI-patiënten $\left(\mathrm{Chi}^{2}=5.21, \mathrm{df}=1, \mathrm{p}=0.02\right)$. De opzet van het onderzoek om te bewerkstelligen dat MI-patiënten en controles niet van elkaar zouden verschillen m.b.t. het voorkomen van pijn in de periode voorafgaande aan de ziekenhuisopname, was daarmee niet gelukt. Besloten werd hiervoor achteraf te controleren.

Met uitzondering van hun leeftijd, zijn er geen gegevens beschikbaar over de weigeraars in beide groepen. De weigeraars verschilden niet in leeftijd met de deelnemers aan het onderzoek $(t=0.83, N S)$.

\subsection{DE MEETINSTRUMENTEN}

Deze paragraaf bespreekt de verschillende meetinstrumenten, die werden gebruikt om de eerder geformuleerde hypothesen en vraagstellingen (par 3.1.) te onderzoeken. 


\section{Slaapklachten}

\section{A. De slaapklachtenlijst van Jenkins}

Algemene slaapklachten werden allereerst gemeten middels de Nederlandse vertaling van de slaapklachtenlijst van Jenkins (1988). Deze lijst meet slaapklachten die voorkomen in de algemene bevolking en bevat 4 vragen. De oorspronkelijke vragenlijst is weergegeven in hfdst 2, tabel 2.5. Deze werd voor het huidige onderzoek aangepast, met achter ieder vraag de gebruikte antwoordcategorieën (bijlage 4).

Op grond van de somscore kan een eerste globale indruk worden verkregen m.b.t. het voorkomen van slaapklachten in de periode voorafgaande aan het hartinfarct.

\section{B. De Slaap-Waak Ervaring Lijst (SWEL)}

Op het moment dat dit onderzoek begon, werkte van Diest aan de ontwikkeling van een instrument om in de algemene bevolking de prevalentie van slaapklachten te kunnen meten. Hiertoe was een itempool van 95 vragen gevormd (bijlage 2). Omdat deze vragenlijst nog niet gereed was aan het begin van het onderhavige onderzoek, werd de gehele lijst overgenomen. Dit stelde ons in staat om zowel onze vraagstelling te onderzoeken als om enkele aanvullende vragen, zoals over de slaapduur, te beantwoorden m.b.v. vragen, die wel in de itempool maar niet in de uiteindelijke lijst waren opgenomen.

Onlangs werd deze lijst gepubliceerd (van Diest et al., 1989) en daarbij de Slaap-Waak Ervaring lijst (SWEL) genoemd. Middels deze lijst is het nu mogelijk om over een gemiddelde 24-uurs-periode klachten over de slaap en het functioneren overdag te meten. Hierbij wordt een onderscheid gemaakt in enerzijds klachten over inslapen, doorslapen, te vroeg wakker worden, moeilijk wakker worden en vermoeid wakker worden, en anderzijds over vermoeidheid en slaperigheid overdag. Voor een uitvoerige beschrijving van de ontwikkeling en validering van de SWEL wordt verwezen naar van Diest et.al. (1989).

De SWEL inventariseert niet alleen systematisch slaapklachten, maar meet eveneens in hoeverre deze chronisch van aard zijn. Slaapklachten worden hierbij "chronisch" genoemd als over een termijn van drie maanden de klacht als "nogal", "erg" of "heel erg" wordt beschreven, en tevens "vaak" of "altijd" aanwezig was. De SWEL onderscheidt een zestal slaapproblemen: problemen met (1) het inslapen; (2) doorslapen; (3) te vroeg wakker worden; (4) moe wakker worden; (5) moeilijk wakker worden en opstaan; en (6) slaperigheid overdag. De klacht vermoeidheid overdag is in de uiteindelijke versie van de SWEL niet opgenomen. In het onderhavige onderzoek gebeurde dit nog wel. De vragen en de daarbij behorende antwoordcategorieën zijn weergegeven in bijlage 5 . 
Op grond van een somscore zal worden nagegaan of hartinfaretpatiënten vaker slaapklachten rapporteerden in de periode voorafgaande aan de ziekenhuisopname vergeleken met controles. Vervolgens zullen de zeven specifieke slaapklachten afzonderlijk worden geanalyseerd.

\section{De vragenlijsten m.b.t. Insomnia \& Hypersomnia}

Tenslotte worden klachten m.b.t. insomnia en hypersomnia gemeten middels een selectie uit de eerdergenoemde itempool, bestaande uit 95 vragen. Deze items zijn vervolgens aan de hand van de literatuur gereduceerd tot een tweetal groepen van vragen, waarmee insomnia en hypersomnia worden gemeten. De tijdsperiode waarover gevraagd wordt betreft de drie maanden voorafgaande aan het hartinfarct.

\section{C.1. Insomnia} ge 6.

De groep over insomnia bestaat uit 17 vragen en is weergegeven in bijla-

Zowel vragen over feiten $(5,6,7,8,12)$, als vragen over ervaren problemen $(1,2,3,4,9,10,11,13,14,15,16,17)$, zijn in deze groep over insomnia opgenomen. Daar informatie m.b.t. ervaren duur (feiten) niet noodzakelijk is (Williams et al., 1988), werden deze vragen uit de groep verwijderd. De intercorrelatie zal uiteindelijk bepalen welke groep gebruikt wordt bij de verwerking van de gegevens.

\section{C.2. Hypersomnia}

De groep over hypersomnia-klachten bestaat uit acht vragen, en is weergegeven in bijlage 7 .

Zowel slaperigheid als vermoeidheid overdag zijn opgenomen, daar beiden als zodanig voor de ondervraagden moeilijk van elkaar te onderscheiden kunnen zijn.

\section{De vragenlijst m.b.t. slaapapneu}

Klachten behorende bij slaapapneu worden opgespoord middels een groep vragen, samengesteld uit de totale itempool, die zowel gaan over problemen met de nachtelijke slaap en met het functioneren overdag, als over specifieke klachten behorende bij slaapapnets. Deze groep bestat uit 24 vragen en is opgenomen in bij!age 8. Allereerst zal deze vragenlijst op haar psychometrische eigenschappen worden onderzocht. Afhankelijk hiervan zullen de somscore's van "cases" en controles op de afzonderlijke factoren met elkaar worden vergeleken. Daarnaast zal deze lijst ook op itemniveau worden geanalyseerd. 


\section{E. De vragenlijst m.b.t. lichamelijke en geestelijke oorzakelijke factoren}

Tenslotte werd aan de hand van 15 aanvullende vragen m.b.t. mogelijke lichamelijke en geestelijke oorzakelijke factoren onderzocht in hoeverre "cases" en controles met slaapklachten ook vaker lichamelijke en/of mentale problemen rapporteerden dan patiënten zonder dergelijke klachten. Deze klachten zijn weergegeven in bijlage 9.

De vragen worden op itemniveau geanalyseerd.

\section{Vitale uitputting}

Ten tijde van de voorbereiding van dit onderzoek werden de gegevens van een prospectief en een "case-control"-onderzoek m.b.t. vitale uitputting geanalyseerd. Vorm B van de Maastrichtse Vragenlijst was toen nog niet gepubliceerd (Appels et al., 1987).

Op grond van de destijds beschikbare informatie werd een vragenlijst met 24 items opgesteld (bijlage 10). Iedere vraag heeft drie antwoordcategorieën: "ja"-"?"-"nee", die respectievelijk worden gescoord als 2-1-0. De minimumscore is zodoende 0 , en de maximumscore 48.

De volgende zeven vragen komen niet voor in vorm B van de Maastrichtse Vragen lijst.

- $\quad$ "Ik kon de laatste tijd erg opvliegend zijn";

- $\quad$ "Kon U de laatste tijd door kleine dingen soms erg geprikkeld raken?"

- $\quad$ "Had U weleens het gevoel dat u uzelf steeds minder in uw macht had?"

- "Was u minder tevreden over uzelf?"

"Voelde u zich gedeprimeerd of teneerges!agen?"

"Voelde u zich minder in staat iets nuttigs te doen?"

"Schudde en beefde u wel eens over uw gehele lichaam?"

De volgende vier vragen zijn niet opgenomen in de hier gebruikte 24 item versie, maar komen wel voor in Vorm B van de MV.

- $\quad$ "Had ù het gevoel dat $u$ in een impasse (in het slop) zit?"

- "Had U de laatste tijd weleens een gevoel van hopeloosheid gehad?"

- $\quad$ "Had U weleens huilbuien?"

"Was het moeilijk voor u geworden om u lang op een ding te kunnen concentreren?"

Bij het analyseren van de MV wordt allereerst nagegaan of hartinfaretpatiẽnten van ziekenhuiscontroles verschillen m.b.t. hun gemiddelde scores. Vervolgens zal de MV-score als een dichotome variabele worden geanalyseerd. De mediaanscore in de controlegroep bepaalt welke personen als "niet uitgeput" dan wel als "uitgeput" worden bestempeld. Tenslotte zal ook een tertielindeling worden gemaakt, waarbij wordt uitgegaan van de indeling die in eerdere onder- 
zoeken naar de relatie tussen VU en het hartinfarct werd gehanteerd. Het betreft hier de categorieën 0-4: "vitaal", 5-22: "matig uitgeput", en 23-48: "uitgeput". Door de MV op deze wijze te analyseren is het mogelijk een vergelijking te maken met zowel het retrospectieve als het prospectieve onderzoek.

\section{III. "Need for Control"}

"Need for Control" werd gemeten middels een vertaalde versie van een in Marburg ontwikkelde vragenlijst (Siegrist et al., 1982), die 51 items bevat. Het oorspronkelijke instrument bestaat uit 6 schalen; "Need for Approval" (schaal 1), "Competitiveness" (schaal 2), "Work Commitment" (schaal 3), en "Perfectionism" (schaal 4), "Time Urgency" (schaal 5), en "Inability to Withdraw from Obligations" (schaal 6). Deze schalen zijn alle unidimensioneel, waarbij de schalen 3 en 6 de grootste interne consistentie te zien geven, met respectievelijke Cronbach's alpha's van 0.76 en 0.54 (Matschinger et al., 1986). Factoranalyse wees uit dat er twee factoren te onderscheiden waren, te weten "Vigor" en "Immersion" (zie ook hoofdstuk 1.6.). Schalen 3 en 4 laadden hoog op "Vigor" (Cronbach's alpha $=0.69$ ) en de overige schalen op "Immersion" (Cronbach's alpha $=0.73$; Matschinger et al., 1986). Deze vragenlijst werd allereerst vertaald en vervolgens getest in een vooronderzoek. Zevenenveertig mannen uit de gemeente Maastricht kregen de lijst toegestuurd, waarbij er uiteindelijk dertig reageerden en commentaar gaven. Aan de hand van hun opmerkingen werden een aantal wijzigingen aangebracht: De inleiding werd uitgebreid, een aantal vragen werd veranderd, en alle vragen werden in de verleden tijd geformuleerd. Omdat de antwoordcategorieën te beperkt werden gevonden en om na te gaan of de aanpassingen een verbetering waren, werd bij 10 personen, d.w.z. 5 hartpatiënten en 5 gezonde personen de nieuwe versie van deze Marburgse lijst mondeling afgenomen. Tijdens deze gesprekken bleken er nagenoeg geen problemen te zijn, behalve opnieuw met de de beperktheid van de antwoordcategorieën. Daarom werd besloten om deze tot een vierpuntsschaal uit te breiden. De antwoordcategorieën zijn thans: "ja!", "ja", "nee", en "nee!" die respectievelijk als $3,2,1$, en 0 werden gescoord. Bij het analyseren van de gegevens zullen de eerste en de tweede categorie en de derde en de vierde categorie worden samengevoegd. Hierdoor wordt het mogelijk de gegevens van dit onderzoek te vergelijken met die uit Marburg. In deze vergelijking worden de antwoordcategorieën "ja!" en "ja" als 1 gescoord en "nee", en "nee!", als 0.

In de analyse van de Marburgse lijst (bijlage 11) zullen zowel de somscore's op de afzonderlijke schalen als de somscores van cases en controles op de beide factoren met elkaar worden vergeleken. Omdat de vragenlijst alleen valide is bij personen met betaald werk zullen de analyses in eerste instantie alleen bij deze groep worden uitgevoerd. 
Bij degenen die in de periode voorafgaande aan hun ziekenhuisopname werkten werd de mate waarin er sprake was van verhoogde werklast gemeten middels een vragenlijst (Bijlage 3;Siegrist 1986, mondeling overleg). Ten minste 4 items moeten positief beantwoord worden teneinde te kunnen spreken van verhoogde werklast.

\section{De Overige vragenlijsten}

\section{A. Angina Pectoris}

Angina pectoris werd gemeten middels de London School of Hygiene Cardiovascular Questionnaire (bijlage 12), ook bekend als de Rose Questionnaire (Rose et al., 1982).

$\mathrm{Er}$ is sprake van AP wanneer de vragen "Had U weleens pijn of een onaangenaam gevoel in de borst (verkoudheid niet meetellen)?" of "Had U weleens aanvallen van beklemmende pijn in de borst?" en "Kreeg U deze druk of pijn als $U$ een helling of trap opliep, als $U$ zich voorthaastte, of als $U$ tegen de wind in liep of fietste?" met ja worden beantwoord. Tevens dient men op de vraag "Wat deed U als U deze druk of pijn kreeg terwijl U liep of fietste?" te antwoorden met "langzamer lopen of fietsen of stilstaan, of een tablet onder de tong nemen" en op de vraag " de druk of pijn verdween dan....?" te antwoorden met "binnen tien minuten". Daarnaast kan de vraag "kreeg $U$ deze druk of pijn als $U$ van warmte in de kou kwam" meegeteld worden,indien deze met ja beantwoord wordt.

\section{B. "Life Events"}

Voor het meten van "Life Events" werd een korte lijst samengesteld, die bestond uit de gebeurtenissen die in eerder onderzoek bleken te discrimineren tussen hartinfartpatiënten en ziekenhuiscontroles (bijlage 13) (Falger, 1989). Hierbij werd aangegeven of de betreffende gebeurtenis in het jaar voorafgaande aan de ziekenhuisopname was voorgekomen. Indien dit het geval was, werd tevens gevraagd om aan te geven inhoeverre de gebeurtenis ingrijpend van karakter was geweest (antwoordcategorieën: "helemaal niet", "nogal", "erg", en "heel erg").

\section{Leefgewoonten}

Aan de hand van een laatste vragenlijst werd op systematische wijze naar een aantal leefgewoonten gevraagd (bijlage 14). Hierbij werd ondermeer bepaald of hartinfarctpatiënten verschillen van ziekenhuiscontroles m.b.t. het gebruik van slaapmiddelen in de periode voorafgaande aan ziekenhuisopname. Daarnaast werd er gevraagd naar roken, koffie- en alcoholgebruik in de periode voorafgaande aan ziekenhuisopname. 


\section{Het Gestructureerd Interview}

Behalve alle bovengenoemde vragenlijsten werd ook nog een interview afgenomen ter bepaling van Type A gedrag. Dit werd gemeten d.m.v. de Nederlandse versie van het Gestructureerde Interview (Rosenman, 1978), dat voor het eerst gebruikt werd in de KRIS (Appels et al., 1982, 1987). De auteur ontving een training in het classificeren van Type A gedrag, waarbij gebruik werd gemaakt van een selectie van de originele banden van de WCGS en de klassificaties uit het bovengenoemde KRIS-onderzoek.

Aan de hand van dit Gestructureerde Interview werden de onderzochte personen ingedeeld in een van de vijf categorieën, namelijk, A1, A2, X, B3, of B4. Deze werden vervolgens gereduceerd tot een tweedeling, te weten; "Type $A$ ", een samenvoeging van Al en $A 2$, en "Type B", de samenvoeging van B3 en B4. Wanneer de onderzoekster geen duidelijk beeld verkreeg werd de Xcategorie gehanteerd, welke in de analyses bij de "Type B" werden gevoegd.

Om organisatorische redenen kon het Gestructureerde Interview niet op geluidsband worden opgenomen. Daardoor was het helaas niet mogelijk om dit interview door derden te laten scoren die onkundig waren van de status van de onderzochte, teneinde inzicht te kunnen krijgen in de betrouwbaarheid van de gegevens m.b.t. type A gedrag.

\subsection{STATISTISCHE ANALYSES}

Bij deze analyses wordt allereerst de verdeling van mogelijke "confounders" bij hartinfarctpatiënten en ziekenhuiscontroles beschreven. Vervolgens worden de gegevens middels univariate en multivariate analyses nader bewerkt.

\section{A. Verdeling van mogelijke "confounders"}

Het doel van deze "confounder" analyse, is erop gericht een inzicht te krijgen in de samenhang van bekende risico-factoren met de onderzoeksvariabelen.

Allereerst wordt middels een t-test tweezijdig getoetst of "cases" en controles van elkaar verschillen m.b.t. leeftijd. Vervolgens wordt aan de hand van 2X2-kruistabellen en $\mathrm{Chi}^{2}$ toetsen (Mantel \& Haenszel, 1959; Mantel, 1963; SPSS-X, 1986) nagegaan of er verschillen zijn tussen hartinfarctpatiënten en ziekenhuiscontroles m.b.t. de variabelen werken, AP, Type A gedrag, roken, koffie- en alcoholconsumptie, en medicijngebruik. Omdat de gerapporteerde "life-events" op ordinaal niveau zijn gescoord, zullen deze d.m.v. de KruskalWallis $\mathrm{Chi}^{2}$-toets worden verwerkt. Tenslotte wordt nagegaan of "cases" en controles verschillen m.b.t. het rapporteren van pijn en ander lichamelijk ongemak 
in de periode voorafgaande aan hun ziekenhuisopname. Indien de respectievelijke verdelingen van deze variabelen een significant verschil opleveren zal hiervoor alsnog worden gecontroleerd.

\section{B. Univariate analyses}

Allereerst worden zowel de absolute als de relatieve frequenties van de onafhankelijke variabelen weergegeven. Tevens wordt waar nodig in het kort ingegaan op de psychometrische eigenschappen van de gebruikte vragenlijsten. Vervolgens worden de gemiddelden, en standaarddeviaties voor de afzonderlijke vragenlijsten berekend, en wordt in univariate analyses getoetst of er verschillen zijn tussen "cases" en controles m.b.t. slaapklachten, de MV, en de Marburgse lijst. De slaapklachtenlijst van Jenkins, de SWEL, de vragenlijsten over insomnia en hypersomnia, de MV, en de Marburgse lijst zullen allereerst als continue variabelen worden geanalyseerd. De slaapklachtenlijst van Jenkins en de SWEL worden, omdat deze van ordinaal niveau zijn, getoetst d.m.v. de Kruskal-Wallis $\mathrm{Chi}^{2}$-toets en de insomnia en hypersomnia-vragenlijsten, de $\mathrm{MV}$ en de Marburgse lijst d.m.v. een t-test (SPSS- $X, 1986$ ).

Vervolgens worden de MV en de SWEL als categorische variabelen op univariaat niveau behandeld, waardoor het mogelijk is om de ruwe relatieve risico's (RR's) te bepalen. Het RR samenhangend met de MV wordt middels programma 2 van Rothman \& Boice (1982) bepaald. De RR's zijn gebaseerd op de puntschattingen volgens Miettinen (1976), met een betrouwbaarheidinterval van $95 \%$. Gezien het feit dat het onderhavige onderzoek een case-control onderzoek is, zijn de RR's geschatte Relatieve Risico's. Uitgaande van de indeling "niet uitgeput" versus "uitgeput" word d.m.v. de Mantel Haenszel$\mathrm{Chi}^{2}$ test getoetst of "cases" en controles vañ elkaar verschillen (Mantel \& Haenszel, 1959; Mantel, 1963). De grens tussen "niet uitgeput" en "uitgeput" wordt hierbij gevormd door de mediaanscore van de ziekenhuiscontroles. Op grond van eerder onderzoek met soortgelijke analyses, wordt tevens gekeken naar de samenhang tussen VU en het hartinfarct, op een tertielindeling gebaseerd (Falger, 1989).

Het RR samenhangend met de scores op de SWEL wordt op dezelfde wijze berekend.

\section{Multivariate analyses}

A priori zijn er een aantal factoren die de relatie tussen slaapklachten en het hartinfarct beinvloeden, zoals pijn, en leeftijd. Hiervoor moet dus worden gecontroleerd. Indien andere factoren een rol spelen dient hiervoor eveneens te worden gecontroleerd. Hierbij wordt gebruik gemaakt van programma 3 van Rothman \& Boice (1982), dat gebaseerd is op Mantel (1963). Allereerst. wordt 
m.b.v. stratificatie nagegaan in hoeverre de "confounders" de mogelijke verschillen tussen cases en controles bepalen. Nadat de heterogeniteits-Chi ${ }^{2}$ is berekend (Mantel et al., 1977), worden d.m.v. de Mantel-Haenszel-Chi ${ }^{2}$ voor gestratificeerde analyses de aangepaste geschatte RR's bepaald, indien er tenminste geen sprake is van een significant verhoogde heterogeniteits-Chi ${ }^{2}$.

Tenslotte zullen de resultaten m.b.v. multiple logistische regressie technieken (BMDP, 1988) worden geanalyseerd. Deze multivariate analyses dienen om voor meerdere -of alle- variabelen, tegelijk te kunnen controleren. 


\section{HOOFDSTUK 4}

\section{VITALE UITPUTTING, "NEED FOR CONTROL", EN ANDERE RISICOFACTOREN EN HUN SAMENHANG MET HET HARTINFARCT}

Dit hoofdstuk met resultaten bevat achtereenvolgens de verdeling van de mogelijke "confounders", en gegevens over vitale uitputting en "need for control" als risicoindicatoren voor het hartinfarct.

\subsection{DISTRIBUTIE VAN DE MOGELIJKE "CONFOUNDERS"}

Bij het werven van MI-patiënten en controles is er naar gestreefd om beide groepen qua leeftijd zoveel mogelijk gelijk te houden. De gemiddelde leeftijd van de MI-patiënten bedroeg 52.96 jaar $(S D=8.65)$ en die van de controles 52.03 jaar $(\mathrm{SD}=8.69 ; \mathrm{t}=0.75, \mathrm{df}=209$, NS). Tussen beide groepen bestaat er dus geen statistisch significant verschil in leeftijd.

Het voorkomen van de categorische variabelen: medicijngebruik, roken, angina pectoris (AP), Type A gedrag, en koffie- en alcoholgebruik is vermeld in tabel 4.1. Uit deze tabel blijkt dat bij MI-patiënten AP, Type A gedrag, werklast, dagelijkse koffie consumptie van 6 of meer dan 6 koppen, en roken significant vaker voorkomen dan bij de controles. Bij de multivariate analyses dienen AP, pijn en overig lichamelijk ongemak, Type A gedrag, dagelijkse koffieconsumptie van 6 of meer dan 6 koppen en roken, dus als mogelijke "confounders" te worden beschouwd.

Bij de analyses van de variabele "need for control" zal verder gecontroleerd worden voor werklast. Zoals aangegeven in Hfdst 1 vormt werklast een belangrijke variabele in het onderzoek naar "immersion". Ook zal ter nadere precisering van de resultaten worden gecorrigeerd voor leeftijd. 
Tabel 4.1. Voorkomen van slaapmiddelengebruik, roken, angina pectoris, Type A gedrag, werken, werklast, kofrie- en alcoholgebruik en pijn en lichamelijk ongemak bij hartinfarctpatiënten en ziekenhuiscontroles

\begin{tabular}{|c|c|c|c|c|}
\hline & MI & CONTROLES & $\mathrm{Chi}^{2}$ & p \\
\hline Variabelen: & (79) & (132) & & \\
\hline Gemiddelde leeftijd/SD: & $52.96(8.65)$ & $52.03(8.69)$ & \multicolumn{2}{|l|}{$0.75 a)$} \\
\hline Roken: & $59(74.7 \%)$ & $76(57.6 \%)$ & 5.56 & .018 \\
\hline \multicolumn{5}{|l|}{$\mathrm{OR}=2.17(1.13-4.21)$} \\
\hline 11-19 sigaretten/dag & $21(37.5 \%)$ & $28(44.4 \%)$ & & \\
\hline$>20$ sigaretten/dag & $24(42.9 \%)$ & $21(33.3 \%)$ & 1.15 & NS \\
\hline \multicolumn{5}{|l|}{$\mathrm{OR}=31.89(6.97-93.69)$} \\
\hline \multicolumn{5}{|l|}{$O R=4.14(2.08-8.30)$} \\
\hline $\begin{array}{l}\text { Slaapmiddelengebruik: } \\
\qquad \mathrm{OR}=0.82(0.23-2.76)\end{array}$ & $5(6.3 \%)$ & $10(7.6 \%)$ & 0.00 & .949 \\
\hline $\begin{array}{l}\text { Dagelijks koffiegebruik } \\
\qquad \mathrm{OR}=1.49(0.82-2.72)\end{array}$ & $72(98.6 \%)$ & $121(92.4 \%)$ & 3.61 & 0.06 \\
\hline \multicolumn{2}{|c|}{ Dagelijkse koffiegebruik 6 of meer koppen: } & & & \\
\hline $\mathrm{OR}=2.03(1.06-3.88)$ & $45(65.2 \%)$ & $62(48.1 \%)$ & 5.33 & .021 \\
\hline \multicolumn{5}{|c|}{ Koffiegebruik voor het slapen gaan: } \\
\hline $\mathrm{OR}=1.45(0.80-2.64)$ & $42(53.2 \%)$ & $58(43.9 \%)$ & 1.34 & .247 \\
\hline \multicolumn{5}{|l|}{$O R=0.79(0.36-1.71)$} \\
\hline \multicolumn{5}{|l|}{$\mathrm{OR}=1.30(0.71-2.36)$} \\
\hline \multicolumn{5}{|l|}{$\mathrm{OR}=4.14(1.71-10.19)$} \\
\hline $\begin{array}{l}\text { Pijn en lichamelijk ongemak: } \\
\quad O R=0.43(0.19-0.96)\end{array}$ & $11(13.9 \%)$ & $36(27.5 \%)$ & 4.34 & .037 \\
\hline $\begin{array}{l}\mathrm{MI}=(\text { myocardinfarct) hartpa } \\
\mathrm{df}=1 \text {, behalve bij: roken }(\mathrm{df} \\
\text { zelden, soms, vaak, altijd. a) }\end{array}$ & Enten. & les $\mathrm{N}=1$ & & \\
\hline
\end{tabular}


Van de sigarettenrokers rookten MI-patiềnten niet meer sigaretten vergeleken met controles. Verder kan uit deze tabel worden opgemaakt dat slaapmiddelengebruik, het al dan niet werkzaam zijn, en het dagelijks drinken van koffie voor het slapen gaan niet van invloed zijn op de mogelijke samenhangen tussen vitale uitputting, slaapklachten, en het hartinfarct. Ook waren er geen verschillen tussen MI-patiënten en controles m.b.t. het gebruik van alcohol in de periode voorafgaande aan de ziekenhuisopname. Het al dan niet werkzaam zijn kan van invloed zijn op het dagelijks activiteitenniveau en daarmede op de slaapgewoonten. Daarom werd nagegaan of werkende MI-patiënten en controles vergeleken met niet werkenden verschilden m.b.t. het rapporteren van slaapklachten. Dit bleek niet het geval te zijn. "Life events" werden in het algemeen wel enigszins vaker door MI-patiënten gerapporteerd, zoals tabel 4.2. aangeeft, maar niet in significante mate. Ook is bekeken of er verschil was tussen MI-patiënten en controles m.b.t. de mate van het ingrijpend zijn van de betreffende gebeurtenissen. Dit was echter niet het geval.

Tabel 4.2.: Voorkomen van "life-events" in de laatste twee jaar voorafgaande aan de ziekenhuisopname bij hartinfarctpatiënten en ziekenhuiscontroles

MI

(79)
CONTROLES

(132)

$\mathrm{Chi}^{2}$

"Life-events":

Financiële problemen

$39(49.4 \%)$

22. $(27.8 \%)$

$15(19.0 \%)$

$52(39.4 \%)$

2.00

Opvoedkundige problemen

$12(15.2 \%)$

$5(6.3 \%)$

$25(3 ! .6 \%)$

22. $(27.8 \%)$

13. $(16.5 \%)$

$15(19.0 \%)$

$32(24.2 \%)$

$26(19.7 \%)$

$17(12.9 \%)$

$6(4.5 \%)$

37 (28.0\%)

$36(27.3 \%)$

$24 .(18.2 \%)$

22 (16.7\%)

is $(14.4 \%)$

$27(20.5 \%)$

$27(20.5 \%)$

$14(10.6 \%)$

8 ( $6.1 \%)$

$10(7.6 \%)$

$50(37.9 \%)$

$19(14.4 \%)$

0.34

0.02

0.22

0.32

$0.3 \mathbf{i}$

0.00

0.10

0.18

0.77

0.37

2.05

0.17

1.90

0.00

0.04

0.01 


\subsection{VITALE UITPUTTING ALS RISICOINDICATOR VAN HET HARTINFARCT}

De gemiddelde score op de MV bedroeg 20.3 (SD=13.7) voor de MI-patiënten en 16.3 $(S D=14.8)$ voor de controles. Dit verschil is significant $(t=1.97$; $\mathrm{p}<0.05$ ). Als de infarctpatiënten en controles worden ingedeeld in de categoriëen "niet uitgeput" en "uitgeput" op grond van de mediaanscore van de controlegroep (d.w.z. 13.5), dan hangt een indeling in de categorie "uitgeput" samen met een relatief risico op een $\mathrm{MI}$ van 2.17 (95\% $\mathrm{BI}: 1.17-4.04$ ).

Tabel 4.3. geeft de antwoordverdeling bij de afzonderlijke items van de MV weer. Zoals blijkt onderscheiden MI-patiënten zich van controles met name m.b.t. vermoeidheid overdag en prikkelbaarheid. Dat pijn een belangrijke "confounder" is in het onderhavige onderzoek blijkt uit Tabel 4.4. Wanneer gecontroleerd wordt voor pijn blijken meerdere items te discrimineren tussen "cases" en controles. Infarctpatiënten klagen vaker over vermoeidheid overdag, problemen met de slaap, prikkelbaarheid, neerslachtigheid en een algehele malaise dan ziekenhuiscontroles.

Tabel 4.3. Antwoordverdelingen m.b.t. de afzonderlijke items van de Maastrichtse Vragenlijst voor hartinfarctpatiënten en ziekenhuiscontroles

MI CONTROLES RR en $95 \%$ BI

(79) (132)

MV-jtems: ja nee ja nee

01: "Voelde $U$ zich in de afgelopen twee tot drie maanden vaak moe?"

02: "Had U er vaak moeite mee in te slapen?" $\quad 33 \quad 46$

$2.25(1.22-4.18)$

$\begin{array}{llll}51 & 28 & 59 & 73\end{array}$

$1.54(0.83-2.86)$

03: "Werd U 's nachts vaak wakker?" $\quad 35 \quad 44 \quad 53 \quad 79$

$1.19(0.65-2.17)$

04: "lk kon de laatste tijd erg opviliegend zijn" $\quad \begin{array}{lllll}55 & 24 & 54 & 78\end{array}$

05: "Voelde U zich vaak slap?"

$\begin{array}{llll}40 & 39 & 50 & 82\end{array}$

$1.68(0.92-3.08)$

06: "Had U het gevoel dat U de laatste tijd weinig presteerde?"

07: "Had U in de afgelopen twee tot drie maanden wel eens het gevoel dat het allemaal wat te veel werd?"

$\begin{array}{llll}47 \quad 32 & 60 & 72\end{array}$

$1.76(0.96-3.23)$

08: "Kon U de laatste tijd door kleine dingen erg geprikkeld raken?" 
vervolg tabel 4.3

09: "Voelde U zich de laatste tijd lustelozer dan vroeger?"

$$
\begin{array}{llll}
46 & 33 & 61 & 71
\end{array}
$$

$1.62(0.89-2.97)$

10: "Had $\mathrm{U}$ weleens het gevoel dat $\mathrm{U}$ uzelf steeds minder in uw macht had?"

$$
\begin{array}{llll}
36 & 43 & 41 & 91
\end{array}
$$

11: "Ik had net zoveel plezier in het sexuele als vroeger?"

$$
\begin{array}{llll}
25 & 54 & 56 & 76
\end{array}
$$

12: "Deed U er langer over om een moeilijk probleem te begrijpen dan een jaar geleden?"

$$
\begin{array}{lllll}
25 & 54 & 33 & 99 & 1.39(0.72-2.69)
\end{array}
$$

13: "Was het zo dat allerlei kleine dingen $U$ meer ergerden dan vroeger?"

$$
\begin{array}{lllll}
55 & 24 & 61 & 71 & 2.56(1.37-4.79)
\end{array}
$$

14: "Hebt U de laatste tijd weleens het verlangen voelen opkomen het bijltje erbij neer te leggen?"

$$
\begin{array}{lllll}
29 & 50 & 48 & 84 & 1.02(0.55-1.89)
\end{array}
$$

15: "Was U minder tevreden over U zelf?"

$\begin{array}{lllll}42 & 37 & 53 & 79 & 1.69(0.93-3.09)\end{array}$

16: "Ik voelde mij de laatste maanden prima"

$\begin{array}{llll}59 & 20 & 77 & 55\end{array}$

2.11(1.09-4.08)

17: "Voelde U zich gedeprimeerd of teneergeslagen?"

$$
\begin{array}{llll}
39 & 40 & 44 & 88
\end{array}
$$

18: "Had U weleens het gevoel dat Uw lichaam een batterij was, waarvan de kracht of het vermogen aan het opraken was ?"

$41 \quad 38 \quad 56 \quad 76$

$1.46(0.81-2.67)$

19: "Voelde $\mathrm{U}$ zich minder in staat iets nuttigs te doen?"

$$
\begin{array}{lllll}
29 & 50 & 43 & 89 & 1.20(0.64-2.25) \\
9 & 79 & 22 & 110 & 0.57(0.23-1.39)
\end{array}
$$

20: "Wilde U soms wel eens dood zijn?"

21: "Had $U$ het gevoel dat U niet meer zoveel waard was als vroeger?"

$$
\begin{array}{llll}
38 & 41 & 59 & 73
\end{array}
$$

22: "Voelde U zich moedeloos?"

$\begin{array}{llll}24 & 55 & 37 & 95\end{array}$

$1.12(0.58-2.16)$

23: "Schudde en beefde U weleens over Uw gehele lichaam?"

$$
\begin{array}{llll}
12 & 67 & 21 & 111
\end{array}
$$

24: "Werd U weleens wakker met een gevoel van uitputting en vermoeidheid?"

$$
\begin{array}{lllll}
27 & 52 & 32 & 100 & 1.62(0.84-3.11)
\end{array}
$$

MI = (myocardinfarct) hartpatiënten 
Uit bovenstaande gegevens blijkt dat de MV een instrument is dat vooral bij gezonde mensen zonder duidelijke lichamelijke klachten voorspelt. Anderzijds discrimineren de items niet bij mensen met een of meerdere duidelijke lichamelijke klachten, met uitzondering van de items die gaan over prikkelbaarheid (tabel 4.4). Door te controleren voor pijn en lichamelijk ongemak wordt het construct dus verder aangezuiverd. Vitale uitputting kan men bijgevolg dus definiëren als een toestand, die gekenmerkt wordt door 1 . gevoelens van vermoeidheid en verlies van energie, 2. toegenomen prikkelbaarheid en 3. gevoelens van demoralisatie, welke toestand niet ontstaat als gevolg van pijn of lichamelijk ongemak.

\section{A. "Confounder"-analyses: Pijn, roken en leeftijd}

Zoals blijkt uit tabel 4.5., hangt pijn duidelijk samen met de scores op de MV. MI-patiënten met pijn scoorden significant hoger dan infarctpatiënten zonder pijn. Dit gold ook voor de ziekenhuiscontroles. Aangezien de controles (28\%) significant vaker pijn rapporteerden dan Ml-patiënten $\left(14 \% ; \mathrm{Chi}^{2}=5.21, \mathrm{p}=0.02\right)$, vormt piin daarmee een "confounder", die een mogelijke anderschatting veraorzaakt van de betekenis van vitale uitputting als risicoindicator voor een infarct.

In een multiple logistische regressieanalyse, waarbij werd gecontroleerd voor pijn, werd nogmaals de hypothese getoetst dat vitale uitputting een risicoindicator voor het hartinfaret vormt. Hierbij werd echter de MV-score ingedeeld in tertielen, volgens de indeling 0-4: "vitaal", 5-22: "matig uitgeput", en 23-48: "uitgeput".

Tabel 4.4.: Geschatte RR's samenhangend met de afzonderlijke items van de Maastrichtse Vragenlijst van hartinfarctpatiënten en ziekenhuiscontroles zonder pijn, en de geschattte RR's aangepast aan pijn

Geschatte RR's Aangepaste RR's en $95 \%$ betrouwhaarheidsintervallen

01: "Voelde $\mathrm{U}$ zich in de afgelopen twee tot drie maanden vaak moe?"

$$
3.3 .3(1.66-6.75)
$$

02: "Had U er vaak moeite mee in te slapen?"

03: "Werd U 's nachts vaak wakker?" $\quad 1.86(0.91-3.80)$

04: "Ik kon de laatste tijd erg opvliegend zijn" 
06: "Had U het gevoel dat U de laatste tijd weinig presteerde?"

$$
2.19(1.06-4.55)
$$

07: "Had U in de afgelopen twee tot drie maanden wel eens het gevoel dat het allemaal wat te veel werd?"

$$
\text { 2.05(1.04-4.06) }
$$

$2.22(1.21-4.06)$

08: "Kon U de laatste tijd door kleine dingen erg geprikkeld raken?"*

$$
3.51(1.73-7.17)
$$

09: "Voelde U zich de laatste tijd lustelozer dan vroeger?"

$$
\text { 2.53(1.27-5.05) }
$$

10: "Had U weleens het gevoel dat $\mathrm{U}$ uzelf steeds minder in uw macht had?"

$$
\text { 2.78(1.34-5.78) }
$$

11: "Ik had net zoveel plezier in het sexuele als vroeger?"

$$
0.82(0.40-1.70)
$$

12: "Deed $\mathrm{U}$ ei langer over om een moeilijk probleem te begrijpen dan een jaar geleden?"

$$
1.78(0.80-4.00)
$$

13: "Was het zo dat allerlei kleine dingen $U$ meer ergerden dan vroeger?"

$$
\text { 2.93(1.46-5.92) }
$$

$3.16(1.71-5.83)$

14: "Hebt U de laatste tijd weleens het verlangen voelen opkomen het bijlije erbij neer te leggen?"

$$
1.21(0.60-2.50)
$$

2.06(1.14-3.74)

15: "Was U minder tevreden over $U$ zelf?"

$$
1.95(0.98-3.89)
$$

2.06(1.14-3.74)

16: "Ik voelde mij de laatste maanden prima"

$$
3.36(1.63-6.98)
$$

17: "Voelde U zich gedeprimeerd of teneergeslagen?"

$$
\text { 2.47(1.20-5.11) }
$$

18: "Had U weleens het gevoel dat Uw lichaam een batterij was, waarvan de kracht of het vermogen aan het opraken was ?"

$$
1.86(0.93-3.70)
$$

$1.36(0.98-3.19)$

19: "Voelde U zich minder in staat iets nuttigs te doen?"

$$
1.69(0.79-3.61)
$$

20: "Wilde U soms wel eens dood zijn?"

$$
0.72(0.24-2.10)
$$

21: "Had $\mathrm{U}$ het gevoel dat $\mathrm{U}$ niet meer zoveel waard was als vroeger?"

$$
1.42(0.71-2.81)
$$


Vervolg tabel 4.4

22: "Voelde U zich moedeloos?"

23: "Schudde en beefde U weleens over Uw gehele lichaam?"

24: "Werd U weleens wakker met een gevoel van uitputting en vermoeidheid?"

* MI patiënten geven eveneens deze klacht vaker aan in de groep met pijn vergeleken met ziekenhuiscontroles $\mathrm{Chi}^{2}=5.49, \mathrm{df}=1, \mathrm{p}=0.02$

Uit tabel 4.6. blijkt verder dat in vergelijking met een score in het laagste tertiel, een score in het middelste tertiel samenhangt met een RR van 2.62(1.225.63), terwijl het risico verbonden aan een score in het derde tertiel 3.75(1.668.48 ) is. Bij controle op leeftijd en roken dalen deze geschatte risico's weliswaar enigermate, maar blijven significant. Rokers blijken zowel een hogere score op de MV te hebben als een groter risico op een infarct te lopen. Ook in de analyse waarin voor al deze factoren tegelijkertijd wordt gecontroleerd, blijkt vitale uitputting de kans op een hartinfarct significant te verhogen.

Tabel 4.5.: Gemiddelde scores (standaard deviaties) op de Maastrichtse Vragenlijst van hartinfarctpatiënten en ziekenhuiscontroles met en zonder pijn

Categorie:

N MV

SD

$1 \quad p$

Patiënten zonder pijn:

MI

controles

Patiënten met pijn:

MI

controles $\begin{array}{ll}68 & 16.70\end{array}$

$\begin{array}{ll}95 & 10.53\end{array}$

$11 \quad 26.52$

$36 \quad 23.54$
11.9

11.0

$2.94 \quad .01$

15.7

15.7

0.86 NS

MI = (myocardinfarct) patiënten; $M V=$ Maastrichtse Vragenlijst; $S D=$ Standaarddeviatie 
Tabel 4.6.: Geschatte RR's van vitale uitputting, gecontroleerd voor pijn, roken, en ieeftijd

Tertiel:

2

Gecontroleerd voor:

pijn

$2.62(1.21-5.66)$

$3.75(1.65-8.52)$

roken

$2.34(1.08-5.04)$

$2.09(1.12-3.91)$

leeftijd

$2.39(1.12-5.11)$

$2.36(1.11-5.04)$

pijn \& roken

$2.57(1.17-5.61)$

$3.65(1.58-8.43)$

pijn, roken \& leeftijd

$2.58(1.18-5.64)$

$3.58(1.54-8.31)$

2 = "matig uitgeput"; 3 = "uitgeput".

\section{B. "Confounder"-analyses: Angina pectoris en pijn en ander lichamelijk ongemak}

Een aparte vraag is hierbij of AP beschouwd moet worden als een "confounder", omdat AP kan leiden tot gevoelens van vitale uitputting. Deze vormen dan een neveneffect van AP. Anderzijds kan men stellen dat AP geen "confounder" is, omdat het een andere verschijningsvorm van coronairlijden is.

Tabel 4. I. gaf reeds eerder aan dat voorafgaande aan de ziekenhuisopname AP werd gerapporteerd door 26 MI-patiënten (32.9\%) tegenover 2 controles $(1.5 \% ; p<.0001)$. Hartinfarctpatiënten met AP hadden een significant hogere gemiddelde score op de MV [27.0 (SD=14.8)] dan patiënten zonder AP [17.0 $(S D=11.9) ; t=3.24, p=0.01]$. De beide ziekenhuiscontroles met $A P$ hadden een onverwacht hoge gemiddelde score op de MV [39.5 ( $\mathrm{SD}=2.1)]$, gelet op de maximum MV-score, d.w.z. 48.

De samenhang tussen vitale uitputting en het infarct - waarbij men controleert voor de invloed van AP - zou het helderst zichtbaar worden gemaakt d.m.v. een gestratificeerde analyse. Men zou daarbij tevens tegelijkertijd moeten stratificeren voor pijn, gelet op de resultaten van tabel 4.5. Bij gelijktijdige controle voor zowel AP als pijn zouden echter teveel strata ontstaan. Bovendien zijn er slechts geringe aantallen MI-patiënten en controles die zowel AP als pijn en lichamelijk ongemak rapporteren (resp. 6 en 1). Daarom is deze analyse alleen uitgevoerd bij personen zonder pijn, waarbij uitgegaan werd van de tertielindeling. Dan blijkt dat vitale uitputting de kans op een hartinfarct ook na controle voor AP meer dan verdubbelt: $R R=2.15(1.07-4.33)$.

\section{De samenhang met Type A gedrag}

Uit de eerdergenoemde data in tabel 4.1. blijkt dat er significant meer MIpatiēnten dan ziekenhuiscontroles als Type $\mathrm{A}$ werden geclassificeerd. 
Een interessante bevinding uit het onderzoek van Falger (1989) was dat juist de combinatie van vitale uitputting en Type A gedrag het risico op een hartinfarct aanmerkelijk verhoogt. Wanneer in de vergelijking met ziekenhuiscontroles niet uitgeputte B Types als referentiekader werden genomen, hadden uitgeputte B Types een significant verhoogd risico van 2.61. Tevens werd gevonden dat degenen die als vitaal uitgeput $A$ Type werden geclassificeerd een significant verhoogd risico liepen van 5.20. Dit risico was aanzienlijk lager, en niet langer significant, wanneer men een niet uitgeput A Type was $(R R=1.94)$.

Er is getracht deze bevinding in dit onderzoek te repliceren. Daarbij werden de analyses beperkt tot die hartinfarctpatiënten en ziekenhuiscontroles waarvan het Type A gedrag bekend was (respectievelijk $68 \mathrm{MI}$-patiënten en $114 \mathrm{ZC}$ ). Evenals in het eerder aangehaalde onderzoek werd "uitgeput" gedefinieerd als een MVscore boven de mediaanscore van de controles (d.w.z. in het onderhavige onderzoek: 13.5). Tabel 4.7. geeft aan dat van alle infarctpatiënten dan $66 \%$ "uitgeput" blijkt te zijn en $43 \%$ als uitgepulte A Types wordt gekenmerkt. Volgens deze tabel hebben niet uitgeputte A's een significant hoger risico dan niet uitgeputte B's, is het geschatte RR voor uitgeputte B's ongeveer gelijk aan dat van niet uitgeputte A's, en hebben uitgeputte A's een bijna negenvoudig risico vergeleken met niet uitgeputte B's. Deze resultaten bevestigen daarmee niet alleen die van het eerdere onderzoek; de hier gevonden verbanden zijn zelfs sterker.

Tabel 4.7. Gestandaardiseerde relatieve risico's voor het krijgen van een hartinfaret bij niet uitgeputte en uitgeputte A en B Typen, zonder pijnlijke aandoeningen

\begin{tabular}{|c|c|c|c|c|c|}
\hline & NUB & NUA & Uitgeput B & Uitgeput $A$ & Totaal \\
\hline MI & 7 & 13 & 14 & 26 & 60 \\
\hline Controles & 28 & 17 & 19 & 12 & 76 \\
\hline Gest RR & 1.00 & 3.06 & 2.95 & 8.67 & \\
\hline $95 \%$ BI & & $1.03-9.07$ & $1.01-8.57$ & $3.11-24.19$ & \\
\hline
\end{tabular}

Tenslotte werd er berekend of er sprake was van een interactie. Dit bleek echter slechts marginaal het geval te zijn $(\mathrm{p}=0.06)$. Beide variabelen leveren daarmee een afzonderlijke bijdrage aan een sterk verhoogd risico op een infarct. 


\section{Samenvatting}

De resultaten uit het onderhavige onderzoek tonen aan dat vitale uitputting een risicoindicator voor het hartinfarct is. Zowel de ruwe als de aangepaste RR zijn significant verhoogd. Pijn blijkt echter een sterke "confounder" te zijn, in de zin dat pijn als oorzaak van gevoelens van uitputting de sterkte van VU als voorloper van het hartinfarct doet onderschatten. Op basis van de gegevens van de tertielindeling van de MV kan geconcludeerd worden dat, naar mate men hoger scoort op de MV, het risico op een infarct eveneens toeneemt. Verder blijkt dat wanneer er zowel sprake is van "uitputting" als van Type A gedrag het RR beduidend hoger is dan wanneer men alleen uitgeput of A Type is. Het lijkt er, tenslotte, op dat vitale uitputting een sterkere risicoindicator voor het hartinfarct is dan Type A gedrag.

\section{3. "NEED FOR CONTROL" ALS RISICOINDICATOR VOOR HET HARTINFARCT: DE MARBURGSE VRAGENLIJST}

Eerdere studies met de Marburgse Vragenlijst hebben aangetoond dat hartinfarctpatiënten in de periode voorafgaande aan hun infarct meer "immersed" waren dan controles (Siegrist, 1984, 1987(b)). Dit betekent dat hartinfarctpatiënten in deze periode hun eigen mogelijkheden om controle over gebeurtenissen te handhaven onderschatten en de eisen vanuit de omgeving overschatten. $\mathrm{Zij}$ geven in feite het beheersen van controle over gebeurtenissen op. Bij degenen waarbij er sprake was van een toegenomen werkdruk, problemen op het werk, en "need for control" (d.w.z. de behoefte om controle over gebeurtenissen te handhaven), was het risico op een MI verhoogd. De Marburgse Vragenlijst werd in dit onderzoek opgenomen om deze "need for control" te kunnen meten, en daarmee bovengenoemde resultaten te kunnen repliceren.

\section{A. Psychometrische eigenschappen}

De lijst werd allereerst op haar psychometrische eigenschappen onderzocht. Varimax-rotatie, waarbij werd uitgegaan van de zes eerder beschreven dimensies (zie hfdst. 3.6.), wees uit dat deze tesamen twee factoren vormden. De dimensies 1, 2, 5 en 6 (resp. "need for approval", "competitiveness", "time pressure" en "inability to withdraw from obligations") iaadden op de eerste factor: deze beschrijft "immersion". De hierbij behorende factorladingen bedroegen respectievelijk: $0.70,0.58,0.67$ en 0.50 . De dimensies 3 en 4 (resp. "work commitment" en "perfectionism") laadden op de tweede factor: deze beschrijft "vigor". De respec- 
tievelijke factorladingen bedroegen 0.83 en 0.54 . De Cronbach alpha's voor de factoren "immersion" en "vigor" waren respectievelijk 0.79 en 0.64. Bij cross-validatie van de factorstructuur van de Marburgse vragenlijst blijkt de factorstructuur identiek.

\section{B. "Need for control" en het hartinfarct}

Zoals tabel 4.8. aangeeft, scoorden hartinfarctpatiënten significant hoger op de factor "immersion" dan de controles, maar niet op de factor "vigor". Deze bevinding is gelijk aan die van eerder onderzoek uit Marburg. Ook daar vertoonden toekomstige MI-patiënten een hogere score op de factor "immersion" (Siegrist, 1984). Het is waarschijnlijk voornamelijk "tijdsdruk" (d.w.z., dimensie 5) die dit verschil verklaart, omdat op de overige dimensies hartinfarctpatiënten en controles niet van elkaar verschilden (tabel 4.8.).

Omdat de eerdere resultaten uit Marburg uitsluitend gebaseerd zijn op gegevens van een werkende populatie, werden bovenstaande berekeningen herhaald bij de werkende MI-patiënten ( $N=44)$ en ziekenhuiscontroles $(\mathrm{N}=65)$. Omdat het hier om betrekkelijk kleine aantallen gaat, was het niet goed mogelijk om multivariate analyses uit te voeren.

Werkende hartinfarctpatiënten scoorden significant hoger dan werkende controles op de factor "immersion" $(\mathrm{t}=2.02 ; \mathrm{df}=90, \mathrm{p}=0.05)$. Dit gold ook voor dimensie 5: "tijdsdruk" $(t=2.40 ; d f=100, p=0.02)$. Diegenen onder de hartpatiënten die aangaven dat er eveneens sprake was van een hoge werklast, vertoonden een hogere score op de factor "vigor", vergeleken met controles $(t=2.06, d f=25$, $p=0.05$ ). Deze groep scoorde eveneens significant hoger dan controles op dimensie 5: "tijdsdruk" ( $\mathrm{t}=2.53$; $\mathrm{df}=25, \mathrm{p}=0.02)$, alsmede op dimensie 4: "perfectionisme" $(\mathrm{t}=2.07, \mathrm{df}=26, \mathrm{p}=0.05)$. Dit betekent dat hartpatiënten, die aangaven dat er sprake was van een hoge werklast, de strijd nog niet hadden opgegeven. Zij overschatten hun capaciteiten en onderschatten de feitelijke last. Door extra inspanning trachtten zij de controle te handhaven.

De Pearson correlatiecoefficienten toonden, tenslotte, aan dat iemands score op de MV wel samenhangt met "immersion" ( $r=0.37, p=0.00)$, maar daarentegen niet met "vigor" $(r=-0.03, p=0.32)$. De correlatie tussen "vigor" en "immersion" bedroeg $0.40(p=0.00)$. Beide factoren hangen dus duidelijk met elkaar samen. Gezien de hoogte van de correlatie met vitale uitputting is de relatie "immersion" hartinfarct echter duidelijker dan die tussen "vigor" en het infarct. Uit bovenstaande gegevens kan dus worden geconcludeerd dat de kans op een hartinfarct verhoogd is wanneer men zowel uitgeput als "immersed" is. Wanneer gecontroleerd wordt voor vitale uitputting verdwijnt het verhoogde risico van "immersion". Vitale uitputting blijkt dus een sterkere risicoindicator te zijn dan "immersion". 
Tabel 4.8. Gemiddelde scores van hartinfarctpatiënten en ziekenhuiscontroles op đe factoren "immersion" en "vigor", en de dimensies 1-6 van de Marburgse Vragenlijst

\begin{tabular}{|c|c|c|c|c|c|c|}
\hline \multirow[b]{2}{*}{ Factoren/Dimensies: } & \multicolumn{2}{|l|}{$\begin{array}{l}\text { MI } \\
\text { (79) }\end{array}$} & \multicolumn{2}{|c|}{$\begin{array}{l}\text { Controles } \\
\text { (132) }\end{array}$} & & \multirow[b]{2}{*}{ p } \\
\hline & $\mathrm{MrV}$ & SD & $\mathrm{MrV}$ & SD & $t$ & \\
\hline "Immersion" & 17.0 & 4.8 & 15.1 & 5.0 & 2.41 & $*$ \\
\hline "Vigor" & 11.5 & 2.6 & 11.4 & 2.4 & 0.36 & \\
\hline I: "need for approval" & 4.0 & 1.5 & 4.0 & 1.5 & 0.20 & \\
\hline 2: "competitiveness" & 3.3 & 1.4 & 2.9 & 1.3 & 1.85 & \\
\hline 3: "work commitment" & 6.0 & 1.6 & 5.9 & 1.5 & 0.84 & \\
\hline 4: "perfectionism" & 5.4 & 1.4 & 5.4 & 1.5 & 0.39 & \\
\hline 5: "time pressure" & 4.4 & 1.6 & 3.9 & 1.8 & 2.18 & * \\
\hline \multicolumn{7}{|c|}{ 6: "inability to withdraw from obligations" } \\
\hline $\begin{array}{l}* \mathrm{P}<0.05 \\
\mathrm{MrV}=\text { Marburgse } \mathrm{Vra} \\
\text { Immersion: } \mathrm{df}=168 ; \mathrm{Vi} \\
\mathrm{df}=191 ; \text { Dimensie } 4: \mathrm{d}\end{array}$ & $\begin{array}{l}=S t \\
2 ; \text { Din } \\
\text { ensie }\end{array}$ & $\begin{array}{l}\text { ddevi } \\
1 \& \\
180\end{array}$ & $=192$ & & $=187$ & Dimensie 3: \\
\hline
\end{tabular}

Ook werd de relatie tussen slaapklachten en de factoren "immersion" en "vigor" getoetst middels een t-test. Hartinfarctpatiënten en controles met doorslaapproblemen scoorden significant hoger op "immersion" $(\mathrm{t}=2.63 ; \mathrm{df}=167, \mathrm{p}=$ 0.009). Dit gold ook voor "vermoeidheid overdag" $(t=2.51, \mathrm{df}=166, \mathrm{p}=0.013)$.

\section{Samenvatting}

In het onderhavige onderzoek bijiken, overeenkomstig de Marburgse bevindingen, hartinfarctpatiënten vergeleken met ziekenhuiscontroles hoger te scoren op de factor "immersion". Een deel van de hartinfarctpatiẻnten heeft als het ware de strijd opgegeven om controle te handhaven over gebeurtenissen. Dit is veelal in strijd met hun persoonlijkheid: het merendeel is immers A Type. Het opgeven van deze strijd gaat samen met een toename in prikkelbaarheid, met vermoeidheid overdag, en met doorslaapproblemen. 
In tegenstelling tot de bevindingen in Marburg blijken hartinfarctpatiënten die werkten en die aangaven dat er sprake was van een verhoogde werklast, hoger te scoren op de factor "vigor". Zij hebben de strijd nog niet opgegeven. Echter, gezien het feit dat het hierbij gaat om een beperkt aantal mensen, moet deze bevinding met enige voorzichtigheid worden betracht. 


\section{HOOFDSTUK 5}

\section{SLAAPKLACHTEN EN HUN SAMENHANG MET HET HARTINFARCT}

\subsection{INLEIDING}

Allereerst zal in dit hoofdstuk het verband tussen slaapduur en algemene slaapklachten en de 'confounders', te weten leeftijd, vitale uitputting, roken, AP, Type A gedrag en koffieconsumptie (zie tabel 4.I.), worden aangesneden. Vervolgens zal de relatie tussen slaapduur en het hartinfarct nader worden uitgewerkt. Uit de literatuur, zoals besproken in Hfdst 1 , is tot nu toe niet geheel duidelijk op te maken of een korte dan wel een lange slaapduur het risico op een hartinfarct verhoogt. Om hierop een antwoord te krijgen, werden hartinfarctpatiënten en ziekenhuiscontroles vergeleken $\mathrm{m}$.b.t. een korte dan wel een lange slaapduur, waarbij een normale slaapduur als referentiekader werd genomen.

Tenslotte wordt de centrale vraag of hartinfarctpatiënten meer slaapklachten voor opname rapporteren dan controles op verschillende manieren onderzocht. Dit geschiedt achtereenvolgens middels a) de slaapklachtenlijst van Jenkins et al., b) de Slaap-Waak Ervaring Lijst (SWEL), c) de uit de totale itempool gevormde clusters 'insomnia' en 'hypersomnia', en d) de symptomen behorende bij slaapapneu. De SWEL werd op verschillende manieren geanalyseerd. Een indicatie over het voorkomen van slaapklachten in het algemeen werd verkregen door de somscore te bepalen. Voor een nadere specificatie van deze klachten werden ook de afzonderlijke categoriëen geanalyseerd, te weten: 'inslapen'; 'doorslapen'; 'te vroeg wakker worden en opstaan'; 'moeilijk wakker worden en opstaan'; 'vermoeid wakker worden en opstaan'; en 'slaperigheid en vermoeidheid overdag'.

$\mathrm{Bij}$ de meeste van deze analyses werd gecontroleerd voor de invloed van pijn. Dit geschiedde om dezelfde redenen als aangegeven in Hfdst 4: er waren achteraf meer controles dan MI-patiënten die aangaven pijn of lichamelijk ongemak te hebben ervaren in de periode voorafgaande aan hun ziekenhuisopname. Verder werd gecontroleerd voor de gebruikelijke 'confounders', namelijk: leeftijd, vitale uitputting, roken, AP, Type A gedrag en koffieconsumptie. Dit gebeurde middels gestratificeerde analyses, zoals eerder vermeld in Hfdst 4. Met behulp van multiple 
logistische regressieanalyses werden tenslotte de relatieve risico's samenhangend met deze slaapklachten bepaald, waarbij gelijktijdig gecontroleerd werd voor de invloed van de eerder genoemde 'confounders'. Type A gedrag werd uit deze laatste analyses weggelaten, omdat niet bij alle hartinfarctpatiënten en ziekenhuiscontroles het Gestructureerd Interview kon worden afgenomen (zie Hfdst 3.5.).

Tenslotte werd nagegaan of er duidelijk aanwijsbare oorzaken waren wanneer hartpatiënten verschilden van controles m.b.t. het rapporteren van bepaalde slaapklachten. Hierbij werd er onderscheid gemaakt tussen somatische en mentale factoren en klachten, behorende bij slaapapneu, zoals aangegeven in Hfdst 3.6.

\subsection{HET VERBAND TUSSEN SLAAPKLACHTEN EN 'CONFOUNDERS'}

Uit tabel 5. 1 . blijkt dat er een duidelijke samenhang bestaat tussen slaapduur en roken, AP, koffieconsumptie, en vitale uitputting.

Tabel 5.1. Absolute en relatieve frequenties van de slaapduur bij rokers, AP, type A gedrag, 6 of meer koppen koffie per dag en de gemiddelde score op de MV

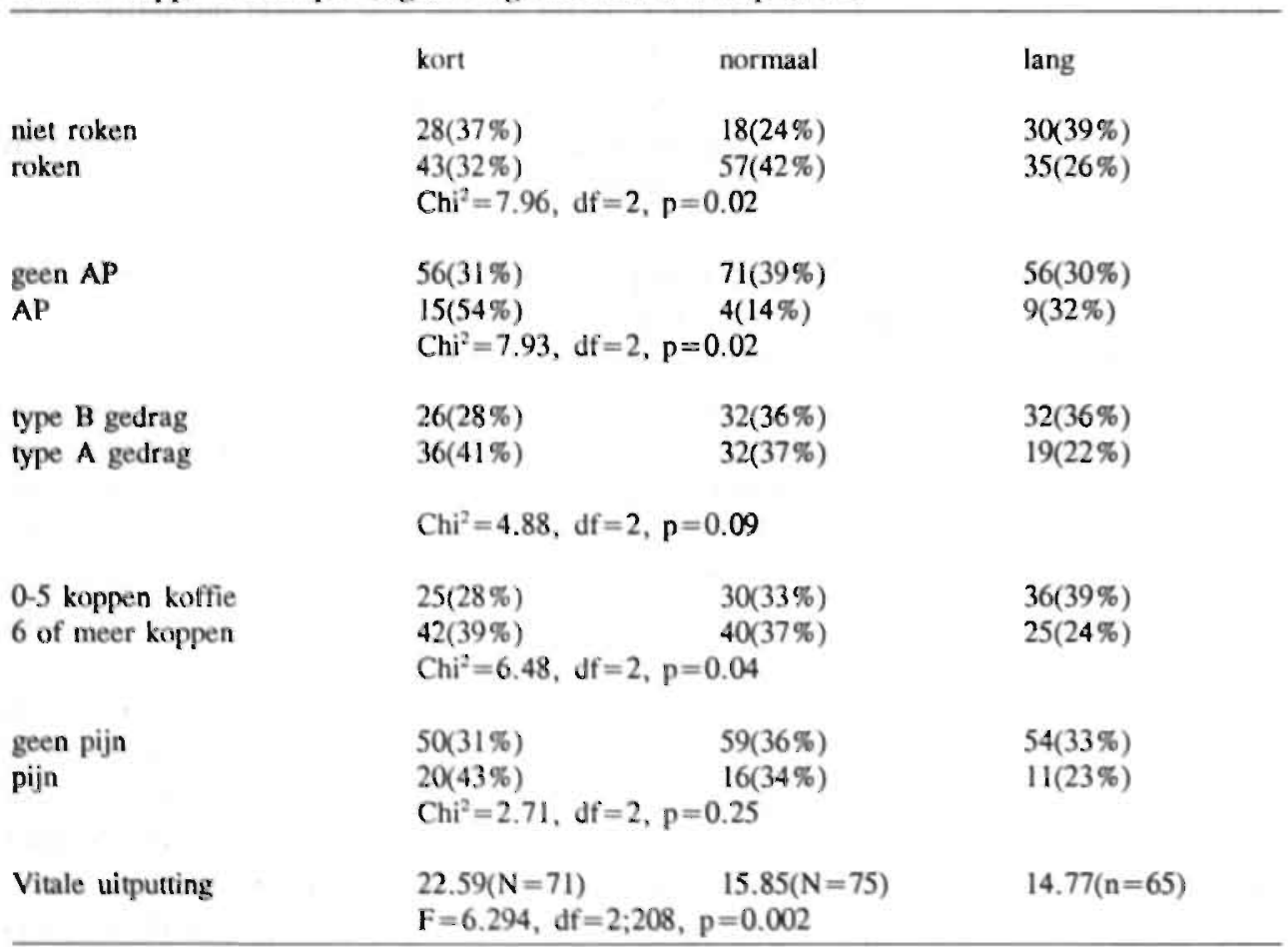


Mensen die niet roken slapen of langer of korter vergeleken met mensen die wel roken. Een korte slaapduur hangt significant samen met AP, vitale uitputting, en/of het drinken van 6 of meer koppen koffie per dag.

Het onderhavige onderzoek heeft echter geen duidelijke relatie kunnen vinden tussen slaapduur en Type A gedrag. Wel is er een duidelijke tendens dat A-types korter slapen dan B-types.

Tabel 5.2. geeft de verschillende samenhangen weer tussen slaapklachten en bovengenoemde 'confounders', waarbij gebruik wordt gemaakt van de slaapklachtenlijst van Jenkins en van de SWEL. Volgens tabel 5.2.I en tabel 5.2.2. komen slaapklachten in het algemeen significant vaker voor bij pijn, AP, en vitale uitputting. Problemen met inslapen, doorslapen, vermoeid wakker worden, slaperigheid overdag en vermoeidheid overdag komen significant vaker voor bij mensen met pijn (tabel 5.2.1.). Slaperigheid overdag komt daarnaast significant vaker voor bij mensen met angineuze klachten in de periode voorafgaande aan hun ziekenhuisopname (tabel 5.2.2.). Dit laatste kan mogelijk verklaard worden omdat men 's nachts niet goed en/of (te) kort slaapt. Tevens komt uit deze tabel een duidelijke samenhang naar voren tussen uiteenlopende slaapklachten en vitale uitputting. Mensen met slaapklachten, d.w.z. problemen met inslapen, doorslapen, te vroeg wakker worden, moeilijk wakker worden, vermoeid wakker worden, slaperigheid overdag, en vermoeidheid overdag, scoren significant hoger op de MV dan mensen die deze klachten niet hebben. Bij deze berekeningen zijn de drie items uit de MV weggelaten die betrekking hebben op slaap (d.w.z. de items 02,03 , en 24 ; zie tabel 4.3.).

Tabel 5.2.1. Het verband tussen slaapklachten en pijn

pijn

slaapklachten algemeen Kruskal Wallis $\mathrm{Chi}^{2}=20,94 \mathrm{p}=0,0001$

Problemen met:

inslapen

doorslapen

te vroeg wakker

moeilijk wakker

vermoeid wakker

slaperigheid overdag

vermoeidheid overdag

$$
\begin{aligned}
& \mathrm{Chi}^{2}=5,13 \mathrm{p}=0,03 \\
& \mathrm{Chi}^{2}=3,53 \mathrm{p}=0,06 \\
& - \\
& \mathrm{Chi}^{2}=21,32 \mathrm{p}<0,0001 \\
& \mathrm{Chi}^{2}=16,74 \mathrm{p}<0,0001 \\
& \mathrm{Chi}^{2}=30,88 \mathrm{p}<0,0001
\end{aligned}
$$


Tabel 5.2.2. Het verband tussen slaapklachten en Angina Pectoris en vitale uitputting

AP

slaapklachten algemeen Kruskal Wallis $=8,99$

Problemen met:

$$
\mathrm{p}=0,003
$$

inslapen

doorslapen

te vroeg wakker

moeilijk wakker

vermoeid wakker

slaperigheid overdag $\mathrm{Chi}^{2}=5,13 \mathrm{p}=0,03$

verinoeidheid overdag
VU

Spearman correlatie $=0,60$

$\mathrm{p}<0,001$

$$
\begin{aligned}
\text { i-test } & =4.37, \mathrm{df}=208, \mathrm{p}<0,0001 \\
& =4,38, \mathrm{df}=205, \mathrm{p}<0,0001 \\
& =3,18, \mathrm{df}=206, \mathrm{p}=0,002 \\
& =2,06, \mathrm{df}=208, \mathrm{p}=0,04 \\
& =6,66, \mathrm{df}=207, \mathrm{p}<0,0001 \\
& =8,38, \mathrm{df}=206, \mathrm{p}<0,0001 \\
& =6,48, \mathrm{df}=208, \mathrm{p}<0,0001
\end{aligned}
$$

In welke mate slaapklachten uitputting veroorzaken dan wel uitputting aanleiding geeft tot slaapklachten kan uit deze analyses niet worden opgemaakt. Er bestaat geen samenhang tussen respectievelijk algemene en specifieke slaapklachten en leeftijd, roken, type A gedrag, en koffieconsumptie.

\section{Samenvatting}

Uit bovenstaande analyses kan worden geconcludeerd dat t.a.v. de gegevens over slaapduur, de variabelen roken, AP, koffieconsumptie, en vitale uitputting belangrijke 'confounders' kunnen zijn. Tevens blijkt er een duidelijke samenhang te bestaan tussen uiteenlopende slaapklachten en AP, pijn en ander lichamelijk ongemak en vitale uitputting.

\subsection{SLAAPDUUR}

Tabel 5.3. geeft de absolute en relatieve frequenties weer van de slaapduur bij MI-patiënten en controles in de drie maanden voorafgaande aan hun opname in het ziekenhuis. Hierbij valt vooral op dat $23 \%$ van de MI-patiënten opgaven korter dan 6 uur geslapen te hebben tegenover $10 \%$ van de controles. Om te toetsen of MI-patiënten in de periode voor het infarct korter dan wel langer sliepen dan controles, werden beide groepen ingedeeld in de drie categoriëen die in het slaaponderzoek gebruikelijk zijn, te weten 'kort' (minder dan 7 uur), 'normaal' (78 uur), en 'lang' (meer dan 8 uur). Zoals blijkt uit tabel 5.4. komt er - na stratifi- 
catie voor pijn - een marginaal significant verschil voor in de groep patiënten zonder pijn. Hartinfarctpatiënten sliepen korter in de periode voorafgaande aan de ziekenhuisopname, vergeleken met controles uit deze groep. Gegeven de belangrijke invloed van pijn op de resultaten worden in de volgende analyses bijna uitsluitend relatieve risico's en $95 \%$ betrouwbaarheidsintervallen vermeld nadat deze zijn aangepast voor pijn en andere 'confounders'. Deze werden berekend d.m.v. gestratificeerde Mantel-Haenszel $\mathrm{Chi}^{2}$ analyses.

Tabel 5.3. Absolute en relatieve frequenties van de slapạduur bij infarcipatiënten en controles

\begin{tabular}{lllllll}
\hline & $<5 u$ & $<6 u$ & $<7 u$ & $<8 u$ & $<9 u$ & $>9 u$ \\
MI & $4(5 \%)$ & $14(18 \%)$ & $15(19 \%)$ & $25(32 \%)$ & $14(18 \%)$ & $79 \%)$ \\
Controles & $5(4 \%)$ & $8(6 \%)$ & $25(19 \%)$ & $50(38 \%)$ & $5(27 \%)$ & $9(7 \%)$ \\
\hline
\end{tabular}

Tabel 5.4. Absolute en relatieve frequenties van de verdeling van đe slaapđuur bij infarctpatiënten en controles, na stratificatie voor pijn
kort
normaal
lang

Patienten zonder pijn: a)

$\begin{array}{llll}\text { MI } & 27(40 \%) & 24(35 \%) & 17(25 \%) \\ \text { Controles } & 23(24 \%) & 35(37 \%) & 37(39 \%)\end{array}$

Patiënten met pijn: b)

$\begin{array}{llll}\text { MI } & 33(42 \%) & 25(32 \%) & 21(27 \%) \\ \text { Controles } & 38(29 \%) & 50(38 \%) & 44(33 \%)\end{array}$

a) $\mathrm{Chi}^{2}=5.46$, df $=2, \mathrm{p}=0.07$; b) $\mathrm{Chi}^{2}=3,75$; df $=2, \mathrm{p}=0.15$

De resultaten zijn samengevat in tabel 5.5. Hieruit blijkt dat zowel bij een relatief korte als bij een lange slaapduur het risico op een infarct niet significant verhoogd was, wanneer werd gecontroleerd voor pijn. Er bestaat evenwel een tendens dat hartpatiënten in de periode voor hun infarct korter slapen dan controles; de ondergrens van het betrouwbaarheidsinterval bedraagt bijna 1.00 . Het risico samenhangend met een korte slaapduur blijkt echter wel significant verhoogd te zijn na gelijktijdige aanpassing voor pijn en roken en voor pijn en Type. A gedrag, en marginaal verhoogd na aanpassing aan koffieconsumptie. Deze risicoindicatoren voor het hartinfarct vormen hier dus 'suppressor' variabelen. Dit betekent dat hartinfarctpatiënten, die geen pijn hadden, maar wel rookten en Type A waren, (en 
veel koffie dronken), korter sliepen dan overeenkomstige controles. De sterkste 'confounder' blijkt AP te zijn. Het verband tussen korte slaapduur en het hartinfarct verdwijnt wanneer men controleert voor AP. Een lange slaapduur blijkt op univariaat niveau het risico op een hartinfarct niet te verhogen. Dit beeld verandert niet na controle voor de opgenomen "confounders".

Middels multiple logistische regressieanalyses werd, tenslotte, nagegaan of een korte dan wel lange slaapduur, na gelijklijdige aanpassing voor de meeste van de bovengenoemde 'confounders', het risico op het krijgen van een hartinfarct significant verhoogt. Dit was echter niet het geval, zoals tabel 5.5. aangeeft. Uit de analyses blijkt wel een tendens dat een korte slaapduur de kans op een hartinfarct verhoogt, namelijk met $89 \%$, terwijl dit bij een lange slaapduur slechts $13 \%$ bedraagt.

Tabel 5.5. Geschatte relatieve risico's samenhangend met korte en lange slaapduur, aangepast voor pijn, pijn en leeftijd, pijn en vitale uitputting, pijn en roken, pijn en type A gedrag en pijn en koffieconsumptie, pijn en angina pectoris en voor alle variabelen tesamen *

Korte slanpduur:

Aangepaste $R R$ en $95 \%$ betrouwbaarheidsintervallen

$\begin{array}{ll}\text { Aangepast voor: } & \\ \text { pijn } & 1.95(0.98-3.88) \\ \text { pijn en leeftijd } & 1.92(0.96-3.83) \\ \text { pijn en vitale uitputting } & 1.70(0.85-3.46) \\ \text { pijn en roken } & 2.33(1.14-4.78) \\ \text { pijn en Type A gedrag } & 2.23(1.03-4.84) \\ \text { pijn en koffieconsumptie } & 2.07(1.00-4.29) \\ \text { pijn en angina pectoris } & 1.37(0.64-2.95) \\ \text { alle variabelen tesamen * } & 1.89(0.80-4.45)\end{array}$

Lange slaapduur:

Aangepast voor:

$\begin{array}{ll}\text { pijñ } & 0.92(0.45-1.88) \\ \text { pijn en leeftijd } & 6.70(0.43-1.83) \\ \text { pijn en vitale uitputting } & 0.95(0.46-1.97) \\ \text { pijn en roken } & 1.13(0.54-2.38) \\ \text { pijn en Type A. gedrag } & 1.25(0.55-2.87) \\ \text { pijn en koffieconsumptie } & 1.04(0.48-2.27) \\ \text { pijn en angina pectoris } & 0.65(0.29-1.44) \\ \text { alle variabelen tesamen * } & 1.13(0.46-2.82)\end{array}$

* Met inbegrip van AP, maar zonder Type A gedrag 


\section{Samenvatting}

Uit het geheel van deze analyses komt het beeld naar voren dat hartpatiënten in de periode voor hun infarct vaker korter sliepen dan personen die om een andere reden in het ziekenhuis waren opgenomen. Dit onderzoek kon echter niet bevestigen dat een korte slaapduur daadwerkelijk tot de determinanten van het hartinfarct behoort. De samenhang tussen korte slaapduur en het hartinfarct wordt zeer waarschijnlijk verklaard door de bekende "confounders", met name AP.

\subsection{DE SLAAPKLACHTENLIJST VAN JENKINS ET AL.}

\section{A. Psychometrische eigenschappen.}

De slaapklachtenlijst van Jenkins et al. (1988) werd allereerst onderzocht op haar psychometrische eigenschappen. Tabel 5.6. toont de absolute en relatieve frequentieverdeling van de items bij hartinfarctpatiënten en controles en rabel 5.7. de Pearson-correlaties tussen de items en met de gehele vragenlijst.

Tabel 5.6. Absolute en relatieve frequenties van slaapklachten bij infarctpatienten en controles, volgens de vragenlijst van Jenkins

1) 'Had $\mathrm{U}$ in de $\mathbf{3}$ maanden voorafgaande aan de ziekenhuisoprame problemen met inslapen?'

$\begin{array}{llllll} & 1 & 2 & i & 4 & 5 \\ \text { MI } & 32(40.5 \%) & 22(27.8 \%) & 20(25.3 \%) & 3(3.8 \%) & 2(2.5 \%) \\ \text { Controles } & 74(56.1 \%) & 28(22.0 \%) & 16(12.1 \%) & 10(7.6 \%) & 3(2.3 \%)\end{array}$

Gemiddelde scores: $\mathrm{MI}=1.00(\mathrm{SD}=1.03)$, Controles $=0.78(\mathrm{SD}=1.07)$.

Kruskal Wallis $\mathrm{Chi}^{2}=3.29, \mathrm{p}=0.07$.

(1: 'helemaal niet'; 2: 'een beetje'; 3: 'nogal'; 4: 'erg'; 5: 'heel erg')

2) 'Hoe vaak bent $U$ in de 3 maanden voorgaande aan de ziekenhuisopname tijdens $U w$ slaap volledig wakker geworden?'

$\begin{array}{llll}1 & 2 & 3 & 4\end{array}$

$\begin{array}{lllll}\text { MI } & 30(38.0 \%) & 21(27.8 \%) & 13(16.5 \%) & 14(17.7 \%) \\ \text { Controles } & 58(43.9 \%) & 35(28.0 \%) & 12(9.1 \%) & 25(18.9 \%)\end{array}$

Gemiddelde scores: $\mathrm{MI}=1.14(\mathrm{SD}=1.12)$, Controles $=1.03(\mathrm{SD}=1.14)$,

Kruskal Wallis $\mathrm{Chi}^{2}=0.57, p=0.45$.

(1: 'minder dan $1 \times$ maand"; 2 : '1-4 $x$ maand'; 3: '1-4 $x$ week'; 4: 'bijna elke nacht') 
Vervolg tabel 5.6

3) 'Had $\mathrm{U}$ in de 3 maanden voorafgaande aan de ziekenhuisopname problemen met te vroeg wakker worden?'

$\begin{array}{lllll}1 & 2 & 3 & 4 & 5\end{array}$

$\begin{array}{llllll}\text { M1 } & 42(53.2 \%) & 18(22.8 \%) & 12(15.2 \%) & 4(5.1 \%) & 3(3.8 \%) \\ \text { Controles } & 89(67.4 \%) & 19(15.2 \%) & 16(12.1 \%) & 5(3.8 \%) & 2(1.5 \%)\end{array}$

Gemiddelde score: $\mathrm{MI}=0.84(\mathrm{SD}=1.10)$, Controles $=0.57(\mathrm{SD}=0.95)$.

Kruskal Wallis $\mathrm{Chi}^{2}=3.14, \mathrm{p}=0.07$.

(1: 'helemaal niet'; 2: 'een beetje'; 3: 'nogal'; 4: 'erg'; 5: 'heel erg')

4) 'Had $U$ in de 3 maanden voorafgaande aan de ziekenhuisopname last van vermoeidheid bij het opstaan ook al had U genoeg geslapen?'

$\begin{array}{llllll} & 1 & 2 & 3 & 4 & 5 \\ \text { MI } & 38(48.1 \%) & 21(26.6 \%) & 11(13.9 \%) & 6(7.6 \%) & 3(3.8 \%) \\ \text { Controles } & 77(58.3 \%) & 26(21.2 \%) & 17(12.9 \%) & 8(6.1 \%) & 2(1.5 \% 0\end{array}$

Gemiddelde score: $\mathrm{MI}=0.92(\mathrm{SD}=1,13)$, Controles $=0.71(\mathrm{SD}=1.01)$.

Kruskal Wallis $\mathrm{Chi}^{2}=1.84, \mathrm{p}=0.17$.

(1: 'belemaal niet'; 2: 'een beetje'; 3: 'nogal'; 4: 'erg'; 5: 'heel erg')

Tabel 5.7. Samenhang tussen de afzonderlijke slaapklachten uit de vragenlijst van Jenkins en met de totale lijst bij infarctpatienten en controles (Pearson correlaties)

$\begin{array}{lllll}\text { Slaapklacht: } & 1 & 2 & 3 & 4 \\ 2 & 0.530 & * * & & \\ 3 & 0.453 & 0.393 & * * & \\ 4 & 0.436 & 0.347 & 0.260 & * * \\ \text { Totale score } & 0.819 & 0.782 & 0.690 & 0.680\end{array}$

1) 'Had $\mathrm{U}$ in de 3 maanden voorafgaande aan de ziekenhuisopname problemen met inslapen?'

2) 'Hoe vaak bent $\mathrm{U}$ in de 3 maanden voorgaande aan de ziekenhuisopname tijdens $U \mathbf{w}$ slaap volledig. wakker geworden?'

3) 'Had U in de 3 maanden voorafgaande aan de ziekenhuisopname problemen met te vroeg wakker worden?"

4) Had U in de 3 maanden voorafgaande aan de ziekenhuisopname last van vermoeidheid bij het opstaan ook al had U genoeg geslapen?' 
De interne consistentie van deze lijst is acceptabel; Cronbach's alpha is 0.71 . In de beide validatiestudies van Jenkins et al. bedroegen deze alpha's 0.79 en 0.63 (Jenkins et al., 1988). Hierbij dient echter vermeld te worden, dat de correlaties tussen item 4: 'vermoeidheid bij het opstaan' en de overige items, met name item 3: 'problemen met te vroeg wakker worden', betrekkelijk laag zijn. 'Vermoeidheid bij het opstaan' heeft dus een betrekkelijk zwakke samenhang met de overige slaapklachten. Omdat de interne consistentie echter acceptabel is, zoals gehanteerd door Jenkins et al., blijft de volledige versie gehandhaafd.

\section{B. Hebben hartinfarctpatiënten meer slaapklachten voorafgaande aan hum ziekenhuisopname dan controles?'}

Uit de frequentieverdelingen in tabel 5.6. bleek dat er sprake is van een scheve verdeling van de antwoorden m.b.t. de aard en de ernst van de slaapklachten. Daarom werd gekozen voor de (niet-parametrische) Kruskal-Wallis test die hiermee rekening houdt, en die het onderscheidend vermogen van de F-test goed benadert (Siegel, 1956).

Tabel 5.8. geeft aan dat de gemiddelde somscore op de Jenkins et al. slaapklachtenlijst voor de totale groep MI-patiënten significant hoger is dan voor de controles. Na stratificatie voor pijn blijkt dat hartpatiënten zonder pijn significant meer slaapklachten rapporteren dan controles. Het gaat hierbij om $75 \%$ van de onderzochte personen. Deze samenhang geldt echter niet voor personen met pijn.

Tabel 5.8. Gemiddelde somscores op de siaapklachtenlijst van Jenkins, voor alle infarctpatiknten en controles tesamen, en na stratificatie voor pijn

Totale groep:

MI

M SD

Controles

$\begin{array}{ll}79 & 3.90\end{array}$

Kruskal Wallis $\mathrm{Chi}^{2}=4.89 ; \mathrm{p}=0.03$

Patiënten zonder pijn:

MI

Controles

Kruskal Wallis $\mathrm{Chi}^{2}=9.93 ; \mathrm{p}=0.002$

Patiënten met pijn:

MI

II $\quad 6.00 \quad(3.55)$

Controles

$\begin{array}{lll}36 & 5.19 \quad(3.53)\end{array}$

Kruskal Wallis $\mathrm{Chi}^{2}=0.32 ; \mathrm{p}=0.57$ 
Uit tabel 5.9. komt naar voren dat wanneer deze verschillen tussen hartinfarctpatiënten en controles worden uitgedrukt als een relatief risico berekend middels een gestratificeerde analyse, dit risico na aanpassing voor pijn en de meeste overige 'confounders' significant verhoogd is. Dit geldt echter niet, wanneer afzonderlijk wordt gecontroleerd voor pijn en vitale uitputting en AP, en wanneer er tegelijkertijd wordt gecorrigeerd voor alle 'confounders', d.w.z. zonder Type A gedrag. Ook deze laatste analyses laten een tendens zien.

\section{Samenvatting}

Wanneer men bovenstaande gegevens en die uit tabel 5.2. combineert, kan worden geconcludeerd dat hartinfartcpatiënten significant vaker dan ziekenhuiscontroles algemene slaapklachten rapporteren in de periode voorafgaande aan hun ziekenhuisopname, en wel omdat zij uitgeputter zijn en vaker angineuze klachten hebben.

Tabel 5.9. Geschatte relatieve risico's samenhangend met slaapklachten uit de vragenlijst van Jenkins, aangepast voor pijn, pijn en leeftijd, pijn en vitale uitputting, pijn en roken, pijn en Type A gedrag, pijn en koffieconsumptie, pijn en angina pectoris en voor alle variabelen tesamen *

Aangepast voor:

Aangepaste RR en $95 \%$ betrouwbaarheidsintervallen

$\begin{array}{ll}\text { pijn } & 1.16(1.05-1.28) \\ \text { pijn en leeftijd } & 1.16(1.05-1.28) \\ \text { pijn en vitale uitputting } & 1.10(0.98-1.23) \\ \text { pijn en roken } & 1.15(1.04-1.28) \\ \text { pijn en Type A gedrag } & 1.15(1.03-1.29) \\ \text { pijn en koffieconsumptie } & 1.16(1.04-1.29) \\ \text { pijn en angina pectoris } & 1.11(0.99-1.25) \\ \text { alle variabelen tesamen * } & 1.12(0.96-1.30) \\ & \\ \text { * Met inbegrip van AP, maar zonder Type A gedrag }\end{array}$

\subsection{DE SLAAP-WAAK ERVARING LIJST (SWEL)}

\section{A. Inleiding}

Middels de Slaap-Waak Ervaring Lijst (SWEL), die uitgebreider is dan de vragenlijst van Jenkins et al. en waarin de antwoordcategoriëen nauwkeuriger worden gespecificeerd, worden de bovenstaande hypothesen en/of exploraties m.b.t. 
slaap en het hartinfarct verder uitgewerkt. Om een hypothese te kunnen toetsen, dient men, wanneer een reeds gepubliceerde test wordt gebruikt, de definities te volgen die aan deze test ten grondslag hebben gelegen. Van Diest et al. (1989) spreken in het kader van de SWEL alleen van een slaapklacht wanneer deze 'nogal', 'erg', of 'heel erg' is en daarbij 'vaak' of 'altijd' voorkomt. Deze definitie wordt dan ook gevolgd bij het toetsen van de hypothesen. Bij de daarop volgende exploraties zal echter ook een uitgebreidere definitie worden gebruikt. Hierbij wordt gesproken van een slaapklacht wanneer deze 'nogal', 'erg', of 'heel erg' is, maar daarnaast 'soms', 'vaak' of 'altijd' voorkomt.

\section{B. Verschillen in somscores op de SWEL}

Uit de absolute en relatieve frequentieverdelingen van de antwoorden op de oorspronkelijke SWEL (tabel 5.10) blijkt dat hartpatiënten en controles slechts weinig van elkaar verschillen. Van de MI-patiënten rapporteerden $39 \%$ een of meerdere slaapklachten in de periode voorafgaande aan hun ziekenhuisopname en van de controles $37 \%\left(\mathrm{Chi}^{2}=0.09\right.$, df $\left.=1, \mathrm{p}=0.76\right)$. Na stratificatie voor pijn bedroegen deze percentages resp. $34 \%$ en $25 \%$ in de groep zonder pijn $(p=0.29)$ en $70 \%$ en $68 \%$ in de groep met pijn $(p=0.81)$. Ook een vergelijking van de somscores van 'cases' en controles geeft aan dat de hartpatiënten en de controles nauwelijks van elkaar verschillen (Kruskal-Wallis test: $\mathrm{Chi}^{2}=0.436, \mathrm{p}=0.509$; in deze toets werd gecorrigeerd voor 'ties'). Bij gebruik van de oorspronkelijke SWEL moet men dus op grond van deze univariate analyses concluderen dat MIpatiënten niet meer slaapklachten voor opname rapporteerden dan controles.

Tabel 5.10. Absolute en relatieve frequenties van slaapklachten bij infarctpatiënten en controles volgens de Slaap-Waak Ervaring Lijst (SWEL)

\begin{tabular}{llllllll}
\hline & 0 & 1 & 2 & 3 & 4 & 5 & 6 \\
MI & $47(61 \%)$ & $8(10 \%)$ & $1 !(15 \%)$ & $4(5 \%)$ & $4(5 \%)$ & $3(4 \%)$ & $0(0 \%)$ \\
Controles & $79(63 \%)$ & $17(14 \%)$ & $19(15 \%)$ & $5(3 \%)$ & $3(3 \%)$ & $1(1 \%)$ & $1(1 \%)$
\end{tabular}

(0: 'geen klachten'; 1: 'een klacht'; 2: 'twee klachten', enz.)

Uit verdere exploraties blijkt echter dat de hartinfarctpatiënten en de controles wel van elkaar verschillen m.b.t. de gerapporteerde incidentele frequentie van hun slaapklachten. Wanneer de categorie 'soms' wordt toegevoegd aan de oorspronkelijke categoriëen 'vaak' en 'altijd' (tabel 5.11.), dan geven hartpatiënten vaker aan 'soms' last te hebben van een bepaalde klacht dan controles (resp 17\% en 10\%). Zou men de definitie van Van Diest et al. in deze zin dan ook verrui- 
men, en daarbij stratificeren voor pijn, dan is het door de hartinfarctpatiënten gerapporteerde aantal slaapklachten significant groter dan bij de controles, d.w.z. resp. $51 \%$ en $35 \%$ in de groep zonder pijn $\left(\mathrm{Chi}^{2}=4.24 ; \mathrm{df}=1, \mathrm{p}=0.04\right)$ en $90 \%$ en $77 \%$ in de groep met pijn $\left(\mathrm{Chi}^{2}=0.80, \mathrm{df}=1, \mathrm{p}=0.37\right)$. In tabel 5.10 werd nog geen rekening gehouden met deze invloed van pijn.

Tabel 5.11. Absolute en relatieve frequenties van slaapklachten bij infarctpatiënten en controles volgens de Slaap-Waak Ervaring Lijst (SWEL), waarbij geldt dat de klacht 'altijd', 'vaak', of 'soms' voorkomt

\begin{tabular}{llllllll}
\hline & & & & & & \\
\\
MI & 0 & 1 & 2 & 3 & 4 & 5 & 6 \\
Controles & $34(44 \%)$ & $27(34 \%)$ & $12(15 \%)$ & $3(4 \%)$ & $2(3 \%)$ & $0(0 \%)$ & $0(0 \%)$ \\
& $67(53 \%)$ & $42(34 \%)$ & $10(8 \%)$ & $3(2 \%)$ & $3(2 \%)$ & $0(0 \%)$ & $1(1 \%)$ \\
(0: 'geen klachten'; 1: 'een klacht'; 2: 'twee klachten', enz.) & & \\
\hline
\end{tabular}

Tabel 5.12. geeft aan, dat na controle op pijn het geschatte relatieve risico significant verhoogd is, bij gebruik van de oorspronkelijke SWEL. Dit geldt eveneens voor gelijktijdige aanpassing voor pijn en leeftijd, roken, Type A gedrag, en koffieconsumptie.

Tabel 5.12. Geschatte relatieve risico's samenhangend met slaapklachten volgens de Slaap-Waak Ervaring Lijst (SWEL), aangepast voor pijn, pijn en leertijd, pijn en vitale uitputting, pijn en roken, pijn en Type A gedrag, en pijn en koffieconsumptie, pijn en angina pectoris, en voor alle variabelen tesamen *

Aangepast voor:

Aangepaste RR en $95 \%$ betrouwbaarheidsintervallen

$\begin{array}{ll}\text { pijn } & 1.35(1.05-1.75) \\ \text { pijn en leeftijdl } & 1.35(1.04-1.74) \\ \text { pijn en vitale uitputting } & 1.15(0.86-1.53) \\ \text { pijn en roken } & 1.35(1.04-1.75) \\ \text { pijn en Type A gedrag } & 1.36(1.01-1.83) \\ \text { pijn en koffieconsumptie } & 1.39(1.05-1.84) \\ \text { pijn en angina pectoris } & 1.32(0.97-1.78) \\ \text { alle variabelen tesamen * } & 1.48(1.00-2.17) \\ & \end{array}$


Het geschatte risico op het krijgen van een hartinfarct, dat samenhangt met het totale scala aan slaapklachten in de SWEL, bedraagt gemiddeld $35 \%$. Dit risico is echter niet langer significant verhoogd, wanneer wordt gecontroleerd voor pijn en vitale uitputting (hetgeen een daling met zich meebrengt van $20 \%$ ), en voor pijn en A.P. In een multiple logistische regressieanalyse blijkt dit risico nog slechts marginaal verhoogd te zijn, wanneer tegelijkertijd alle 'confounders' m.u.v. Type A gedrag in de vergelijking worden betrokken: de onderste limiet van het betrouwbaarheidsinterval bedraagt precies 1.00. Deze multivariate analyse leidt daarmee tot enigszins andere resultaten dan de univariate resultaten.

\section{Samenvatting}

Wanneer ook nu weer deze gegevens en die uit paragraaf 5.2. worden gecombineerd, dan ontstaat het beeld dat slaapklachten het risico op een hartinfarct verhogen omdat men uitgeput is geraakt. Men kan tevens dezelfde conclusie trekken t.a.v. AP. Slaapklachten differentiëren in de univariate analyses omdat hartpatiënten vaker angineuze klachten rapporteren dan ziekenhuiscontroles. Als gevolg van deze (meestal nachtelijke) pijn kan men 's nachts niet meer goed slapen. Personen met AP slapen bovendien korter en geven aan last te hebben van slaperigheid overdag.

\section{Nadere specificatie van de slaapklachten}

In bovenstaande toetsende analyses en verdere exploraties werden alle klachten die samenhangen met de nachtelijke slaap of met het functioneren overdag bij elkaar opgeteld. Om de vraag te kunnen beantwoorden of er ook specifieke slaapklächten zijn aan te geven in de periode voorafgaande aan heit hartinfarct werden de afzonderlijke groepen slaapklachten uit de oorspronkelijke SWEL geanalyseerd. Tabel 5.13 geeft de resultaten weer.

Uit deze tabel blijkt dat tiitsluitend klachten m.b.t. moeilijk wakker worden significant vaker voorkomen bij MI-patiënten, maar ook dat het hierbij om een kleine minderheid gaat $(\mathrm{N}=5)$. In deze tabel werd geen onderscheid gemaakt tussen personen met en zonder pijn.

Na stratificatie voor pijn geven MI-patiënten zonder pijn significant vaker aan dat zij problemen hadden met doorslapen (16\%) en ook dat zij zich overdag vaker vermoeid voelden $(19 \%)$ dan ziekenhuiscontroles (resp. $5 \%$ en $8 \% ; p=.02$, resp. $\mathrm{p}=.04)$. Bij personen met pijn komen deze specifieke klachten enigszins vaker bij ziekenhuiscontroles voor, maar niet in significante mate $(p=88$, resp. $\mathrm{p}=.70)$. 
Tabel 5.13. Absolute en relatieve frequenties van slaapklachten bij infarctpatiënten en controles volgens de Slaap-Waak Ervaring Lijst (SWEL)

Klachten m.b.t.:

MI Controles $\mathrm{Chi}^{2} \quad \mathrm{P}$

inslapen

doorslapen

te vroeg, wakker worden

moeilijk wakker worden

vermoeid wakker worden

slaperigheid overdag.

vermoeidheid overdag

$\begin{array}{cccc}12(15.2 \%) & 18(13.7 \%) & 0.09 & 0.77 \\ 13(16.7 \%) & 13(10.1 \%) & 1.92 & 0.17 \\ 8(10.1 \%) & 10(7.8 \%) & 0.35 & 0.55 \\ 4(5.1 \%) & 1(0.8 \%) & 3.92 & 0.05 \\ 10(12.7 \%) & 12(9.2 \%) & 0.61 & 0.43 \\ 10(12.7 \%) & 18(13.6 \%) & 0.03 & 0.87 \\ 17(21.8 \%) & 23(17.7 \%) & 0.53 & 0.47\end{array}$

Wanneer er gecontroleerd wordt voor pijn, blijken de relatieve risico's die samenhangen met deze slaapklachten weliswaar te zijn verhoogd, maar niet in significant mate, zoals weergegeven in tabel 5. 14. In deze tabel zijn de ruwe relatieve risico's vermeld in kolom I, de risico's aangepast voor pijn in kolom II, en die voor alle 'confounders' tesamen, m.u.v. Type A gedrag, in kolom III. Behalve 'moeilijk wakker worden' (kolom II), bleek geen van de specifieke slaapklachten het risico op een hartinfaret significant te verhogen. Zoals hierboven vermeld, zijn deze laatste gegevens slechts gebaseerd op vijf personen, d.w.z. vier MI-patiënten en een ziekenhuiscontrole. Het bijbehorende betrouwbaarheidsinterval is dan ook buitengewoon breed.

Tabel 5.14. Geschatte ruwe relatieve risico's, samenhangend met slaapklachten volgens de SlaapWaak Ervaring Lijst (SWEL) (kolom I), en geschatte relatieve risico's aangepast voor pijn (kolom II) en voor alle variabelen tesamen (met inbegrip van AP) (kolom III)

Klachten m.b.t.:

inslapen

doorslapen

te vroeg wakker worden

moeilijk wakker worden

vermoeid wakker worden

slaperigheid overdag

vermoeidheid overdag
I

II

[I] 
Wanneer gelijktijdig wordt gecontroleerd voor alle confounders, m.u.v. Type A gedrag, blijken 'doorslaapproblemen' het risico op een hartinfarct ruim tweevoudig, en bovendien significant, te verhogen.

Zoals eerder opgemerkt spreken Van Diest et al. m.b.t. de oorspronkelijke SWEL over een slaapklacht wanneer men daar 'vaak' of 'altijd' door wordt geplaagd. Wanneer men deze definitie volgt, zoals tot nu toe is geschied, dan moet men besluiten dat dit onderzoek heeft aangetoond dat vooral klachten $\mathrm{m}$.b.t. doorslapen de kans op een hartinfarct verhogen, na gelijktijdige correctie voor de 'confounders'.

Als men echter ook van een slaapklacht spreekt wanneer de frequenties 'soms', 'vaak', en 'altijd' inhouden, dan blijken er meer specifieke slaapklachten voor te komen in de periode voorafgaande aan het infarct (Tabel 5.15). Het gaat hierbij opnieuw om doorslaapproblemen en om vermoeidheid overdag. De betreffende relatieve risico's, wanneer wordt gecontroleerd voor pijn, zijn significant verhoogd, zoals Tabel 5.16 (kolom II) aangeeft. Bij correctie voor pijn blijken bovendien 'inslaapproblemen' alsmede 'slaperigheid overdag', naast 'doorslaapproblemen' en 'vermoeidheid overdag', het risico op een hartinfarct significant te verhogen. Deze risico's lopen uiteen van bijna tweevoudig tot ruim drievoudig.

Tabel 5.15. Absolute en relatieve frequenties van slaapklachten bij infarctpatiënten en controles, zoals gemeten met de Slaap-Waak Ervaring Lijst (SWEL), waarbij de betreffende klacht 'nogal', 'erg', of 'heel erg' is en 'soms', 'vaak' of 'altijd' voorkomt

\begin{tabular}{llclc} 
Klachten m.b.t.: & MI & Controles & Chi $^{2}$ & $p$ \\
inslapen & & & & \\
doorslapen & $24(30.4 \%)$ & $27(20.6 \%)$ & 2.55 & 0.18 \\
te. vioeg, wakker worden & $29(37.2 \%)$ & $25(19.4 \%)$ & 7.95 & 0.06 \\
moeilijk wakker worden & $15(19 . . \%)$ & $17(13.2 \%)$ & 1.26 & 0.28 \\
vermoeid wakker worden & $8(10.1 \%)$ & $5(5.3 \%)$ & 1.69 & 0.24 \\
slaperigheid overdag & $15(19.0 \%)$ & $20(15.4 \%)$ & 0.46 & 0.45 \\
vermoeidheid overdag & $37(47.4 \%)$ & $52(39.4 \%)$ & 1.29 & 0.28 \\
& $33(42.3 \%)$ & $34(26.2 \%)$ & 5.83 & 0.03 \\
\hline
\end{tabular}

Wanneer men middels multiple logistische regressie controleert voor alle 'confounders' tesamen (kolom III), blijven alleen 'doorslaapproblemen' een significant verhoogd risico op een hartinfarct inhouden [RR $=2.60(1.16-5.80)]$. Uit deze analyses met een uitgebreidere definitie van slaapklachten blijkt dus wederom dat de relatie tussen slaapklachten en het hartinfarct voornamelijk wordt bepaald door pijn en vitale uitputting, en in mindere mate door (nachtelijke) angineuze klachten. Dit geldt echter niet voor doorslaapproblemen, die een zelfstandige bijdrage leveren. 
Tabel 5.16. Geschatte ruwe relatieve risico's, samenhangend met slaapklachten volgens de SlaapWaak Ervaring Lijst (SWEL), waarbij de betreffende klacht 'nogal', 'erg' of 'heel erg' is en 'soms', 'vaak' of 'altijd' voorkomt (kolom I), en geschatte relatieve risico's aangepast voor pijn (kolom II)

I

Klachten m.b.t.:

inslapen

doorslapen

te vroeg wakker worden

moeilijk wakker worden vermoeid wakker worden slaperigheid overdag vermoeidheid overdag

$1.68(0.89-3.18)$
$2.46(1.32-4.61)$
$1.54(0.72-3.29)$
$2.00(0.70-5.66)$
$1.29(0.62-2.70)$
$1.39(0.79-2.45)$
$2.07(1.15-3.75)$

$1.68(0.89-3.18)$

$2.00(0.70-5.66)$

$1.39(0.79-2.45)$

$2.07(1.15-3.75)$
II

III

\section{Samenvatting}

Doorslaapproblemen, zoals gemeten met de oorspronkelijke SWEL, verhogen het risico op een hartinfarct ruim tweevoudig. Dit resultaat is niet te verklaren a.g.v. vitale uitputting, pijn of lichamelijk ongemak of AP.

\section{6. 'INSOMNIA' EN 'HYPERSOMNIA'}

Gegeven de zeer hoge correlatie tussen cluster I, waarin zowel werd gevraagd naar klachten als naar feiten m.b.t. insomnia, en cluster II, waarin uitsluitend werd gevraagd naar klachten $(r=0.984)$, werden de verdere analyses met cluster 1 uitgevoerd. Cronbach's alpha m. b.t. deze items bedroeg 0.93 . Factoranalyse leverde een factor met een eigenwaarde van 7.94 op, welke $46.7 \%$ van de variantie verklaart. De opgenomen factorladingen waren alle groter dan 40 .

Insomnia, zoals gemeten middels de groepering van 17 vragen uit de itempool waaruit later de SWEL is ontstaan (Hfst 3.6.), werd gemiddeld niet vaker gerapporteerd door de hartinfarctpatiënten dan door de controles $(t=1.69, \mathrm{df}=209$; $\mathrm{p}=0.093$ ).

Ook voor de acht vragen m.b.t. hypersomnia gold dat deze klachten gemiddeld niet vaker door hartpatiënten dan door ziekenhuiscontroles werden geuit $(t=1.29$, $\mathbb{d f}=209 ; p=0.198)$. Cronbach's alpha bedroeg hier 0.79 . Na factoranalyse was er een factor gevormd met een eigenwaarde van 3.52 , welke $43.9 \%$ van de variantie verklaarde.

Evenals bij de meeste voorafgaande analyses, werd vervolgens een onderscheid gemaakt tussen personen met en zonder pijn. Na deze stratificatie bleek dat 
in de groep zonder pijn hartinfarctpatiënten significant vaker klaagden over insomnia en hypersomnia dan ziekenhuiscontroles, zoals tabel 5.17 aangeeft.

Tabei 5.17. Gemiddelde somscores van infarctpatiēnten en controles m.b.t. 'insomnia' en 'hypersomnia', na stratificatie voor pijn, en de geschatte relatieve risico's aangepast voor pijn

Patiēnten zonder pijn:

N Gemiddelde score (Standaarddeviatie)

Insomnia I:

MI

68

$16.82(11.21)$

Controles

95

$12.16(8.98)$

$t=2.95, d f=161, p=0.004$.

Hypersomnia:

MI 68

$10.35(5.29)$

Controles

95

$8.49(4.59)$

$t=2.39, \mathrm{df}=161, \mathrm{p}=0.002$.

Patiënten met pijn:

Insomnia I:

MI

Controles

11

$t=0.15$, df $=45, p=0.88$.

Hypersomnia:

MI 11

$14.73(6.25)$

Controles

36

$13.75(6.16)$

$\mathrm{t}=0.46, \mathrm{df}=45, \mathrm{p}=0.65$.

Geschatte RR aangepast voor pijn en $95 \%$ betrouwbaarheidsintervallen

Insomnia

$1.04(1.01-1.06)$

Hypersomnia

$1.07(1.01-1.13)$

Het geschatte RR die samenhangt met insomnia, gecontroleerd voor pijn, is significant verhoogd $[R R=1.04(1.01-1.06)]$. Het is bij deze analyses van belang te bedenken dat het om continue variabelen gaat. Dit betekent dat een verhoging. van de score met een punt het risico verhoogt met $4 \%$. Wanneer eveneens wordt gecontroleerd voor pijn en leeftijd, pijn en roken, pijn en koffieconsumptie, en pijn en Type A gedrag, verandert dit risico niet noemenswaardig. Dit significant verhoogde risico verdwijnt echter na correctie voor pijn en vitale uitputting en pijn en AP, en tevens wanneer voor alle 'confounders' tegelijk, wordt gecontroleerd, m.u.v. Type A gedrag. 
Ook het risico dat samenhangt met hypersomnia is significant verhoogd, na controle voor pijn $[R R=1.07(1.01-1.13)]$. Bij deze klachten neemt het risico op een hartinfarct dus toe met $7 \%$ n.a.v. iedere volgende bevestigde klacht. Evenals bij insomnia geldt dat dit risico niet noemenswaardig verandert na correctie voor de bovengenoemde 'confounders', opnieuw met uitzondering van pijn en vitale uitputting en pijn en AP (en bovendien bij pijn en roken), en bij controle voor alle 'confounders' tegelijkertijd, m.u.v. Type A gedrag.

\section{Samenvatting}

Uit bovenstaande bevindingen kan worden opgemaakt dat hartinfarctpatiënten meer klachten hebben m.b.t. de nachtelijke slaap en hun functioneren overdag in de drie maanden voorafgaande aan de ziekenhuisopname dan ziekenhuiscontroles. Er blijkt tevens uit dat deze problemen grotendeels samenhangen met de vitale uitputting en de angineuze klachten die in deze periode ontstaan of reeds aanwezig waren.

\subsection{LICHAMELIJKE EN GEESTELIJKE OORZAKELIJKE FACTOREN}

Zoals in Hfdst 3 is uiteengezet, werden er ook enkele mogelijke oorzakelijke factoren van de hier bestudeerde slaapklachten onderzocht. In tabel 4.1. werd reeds vermeld dat ziekenhuiscontroles vaker klaagden over pijn of lichamelijk ongemak in de periode voorafgaande aan de ziekenhuisopname dan hartpatiënten. In deze analyse gold dat de betreffende klacht 'vaak' of 'altijd' voorkwam. De partners van hartpatiënten gaven tevens vaker aan dat hun echtgenoot in de drie maanden voorafgaande aan het infarct onregelmatig ademde in zijn slaap $\left(\mathrm{Chi}^{2}=4.67\right.$; df $=1, p=0.03: N=21[27 \%]$ ), dan wel dat van de toekomstige hartinfarctpatiënt en meer benauwd daaruit wakker werd dan van de controles $\left(\mathrm{Chi}^{2}=4.06 ; \mathrm{df}=1\right.$, $\mathrm{p}=0.04: \mathrm{N}=18[23 \%]$ ). Tabel 5.18. geeft de overige resultaten m.b.t. mogelijk oorzakelijke factoren, zowel lichamelijke als geestelijke, op itemniveau weer. Behalve de reeds genoemde zijn er geen significante verschillen tussen beide groepen patiënten.

In paragraaf 5.5. werd gevonden dat 'doorslaapproblemen' een significant verhoogd risico voor een hartinfarct inhielden, na controle voor alle "confounders" tesamen. Personen die doorslaapproblemen rapporteren $(\mathrm{N}=26)$, ongeacht of het om een infarctpatiënt of een ziekenhuiscontrole gaat, geven gemiddeld vaker geestelijke factoren als mogelijke oorzaak aan dan degenen zonder dergelijke klachten $[(\mathrm{N}=176) ; \mathrm{t}=2.72, \mathrm{df}=200, \mathrm{p}=.007]$. Het gaat hierbij vooral om angst om niet 
in slaap te kunnen vallen $\left(\mathrm{Chi}^{2}=19.93, \mathrm{df}=1, \mathrm{p}<.0001\right)$, en in mindere mate om het zich zorgen maken voor het inslapen $\left(\mathrm{Chi}^{2}=5.05, \mathrm{df}=1, \mathrm{p}=.03\right)$ dan wel om verdrietige of sombere gevoelens $\left(\mathrm{Chi}^{2}=4.74, \mathrm{df}=1, \mathrm{p}=.03\right)$. In deze groep kwamen pijn en lichamelijk ongemak ook significant vaker voor dan in de groep van personen zonder doorslaapproblemen $\left(\mathrm{Chi}^{2}=4.54, \mathrm{df}=1, \mathrm{p}=.03\right)$. Tenslotte vermeldden de partners van de personen met doorslaapklachten significant vaker dat deze 's nachts snurkten dan personen zonder deze klachten $\left(\mathrm{Chi}^{2}=3.91, \mathrm{df}=1\right.$, $\mathrm{p}=.048$ ).

Tabel 5.18. Lichamelijke en geestelijke oorzakelijke factoren, waarbij de betreffende klachı 'vaak' of 'altijd' voorkomt

A. lichamelijke factoren:

$\begin{array}{ll}\text { Cases } & \text { Controles } \\ \mathrm{N} & \mathrm{N} \%\end{array}$

'Hoe vaak:

1. kon U voor het inslapen uw benen onmogelijk stilhouden?'

13 (16.5) $27(20.6)$

2. had u last van pijn of lichamelijk ongemak?'

$11(13.9) 36(27.5) *$

3. had $\mathrm{u}$ bij het inslapen het gevoel dat $\mathrm{u}$ zich niet meer kon bewegen?

$1(1.3) \quad 18(13.6)$

4. werd u wakker met pijn of prikkeling in de benen?'

$8(10.1) \quad 18(13.6)$

5. werd u benauwd wakker uit uw slaap?

$6(7.7) \quad 6(4.5)$

6. werd u wakker met pijn in armen en benen?'

$8(10.1) \quad 15(11.4)$

7. werd u wakker met hoofdpijn?'

8. 'Weet $U$ via Uw partner of anderen dat u snurkt tijdens uw slaap?'

$8(10.1) \quad 7(5.3)$

$60(76) \quad 88(67)$

\section{B.Geestelijke factoren:}

'Hoe vaak:

1. maakte $U$ zich zoigen voor het inslapen?'

2. had $\mathrm{U}$ voor het inslapen last van een verdrietig of somber gevoel?

$\begin{array}{ll}\text { Cases } & \text { Controles } \\ \text { N } \% & \text { N } \%\end{array}$

3. voelde U zich angstig voor het inslapen?'

I0 (4.7) $17(12.9)$

$9(11.4) \quad 8(6.1)$

$3(3.8) \quad 7(5.3)$

$\begin{array}{lll}\text { 4. was U bang niet in slaap te kunnen vallen?' } & 9(11.4) & 8(6.1) \\ \text { 5. had u last van nachtmerries?' } & 3(3.8) & 7(5.3)\end{array}$

6. werd u wakker uit een droom?'

$6(7.6) \quad 6(4.6)$

7. had u een steeds terugkerende droom die de slaap verstoorde?' $\quad 2(2.5) \quad 4(3.0)$

8. voelde u zich verward bij het wakker worden?' $3(3.8) 5(3.8)$

$* \mathrm{p}<0.05$.

Vanwege het betrekkelijk geringe aantal personen met doorslaapklachten $(\mathrm{N}=26)$ werden deze gegevens niet af́zonderlijk voor hartinfarctipatiënten en ziekenhuiscontroles geanalyseerd. Deze gegevens suggereren echter dat doorslaapproblemen tot een vicieuze cirkel kunnen leiden, waarin vooral de angst om niet in 
slaap te kunnen vallen een belangrijke rol speelt. Na controle voor bovengenoemde klachten die mogelijk duiden op apneu, te weten het onregelmatig ademen in de slaap, benauwd wakker worden uit de slaap en hevig snurken tijdens de slaap, ziet men dat men te maken heeft met een op zichzelf staande klacht. Het geschatte relatieve risico wordt nog sterker $[R R=5.97(95 \% \mathrm{BI}=1.74-20.5)]$.

Uit deze gegevens kan men dus concluderen dat slaapklachten in de periode voorafgaande aan de opname bij ziekenhuiscontroles grotendeels verklaard worden door somatische factoren, d.w.z. last van pijn of lichamelijk ongemak. Doorslaapproblemen blijken een op zichzelf staande klacht te zijn welke het risico op het hartinfarct significant verhoogt. Dit verhoogde risico verdwijnt niet na controle voor AP, VU en/of "slaapapneu".

\subsection{SLAAPAPNEU}

Behalve vragen over insomnia en hypersomnia waren er in dit onderzoek ook enkele vragen over slaapapneu opgenomen, gelet op de grote betekenis die hieraan recent in de literatuur wordt gegeven (Hfdst 2.7.). De groep vragen m.b.t. slaapapneu, waarmee deze klachten gemeten zouden moeten worden, was echter zeer waarschijnlijk niet specifiek genoeg. Psychometrisch onderzoek toonde weliswaar aan dat Cronbach's alpha .87 bedroeg, dat twee factoren met resp. eigenwaardes van 6.95 en 2.77 in totaal $40.6 \%$ van de variantie verklaarden (resp. $29.0 \%$ en $11.6 \%$ ), en dat de Pearsoncorrelatie tussen beide factoren .49 bedroeg. Inspectie van de factoren laat echter zien dat het in feite om de eerder genoemde groepen vragen m.b.t. insomnia en hypersomnia gaat, waaraan de items: 1 .'Hoe vaak had U het benauwd als U uit uw slaap wakker werd?' en 2 . 'Hoe vaak voelde U zich verward bij het wakker worden?' zijn toegevoegd.

Het geschatte RR m.b.t. de totale groep vragen over slaapapneu bedraagt 1.05(1.03-1.09), wanneer wordt gecontroleerd voor pijn. Dit risico blijft significant verhoogd bij controle voor de afzonderlijke 'confounders'. Dit werd eveneens gevonden bij de analyse van beide factoren afzonderlijk. Het geschatte RR is bij beide factoren significant verhoogd, na controle voor pijn, en bedraagt 1.07(1.021.12) voor factor 1 en $1.10(1.03-1.17)$ voor factor 2 . Wanneer tegelijkertijd gecontroleerd wordt voor pijn en vitale uitputting is het geschatte risico bij factor 1 echter niet langer significant, d.w.z. 1.05(0.99-1.10). Dit betekent dat vitale uitputting een 'confounder' is, evenals in de meeste van de bovenstaande analyses. De risico's die samenhangen met factor 1 en 2 zijn eveneens niet langer significant wanneer voor alle eerdergenoemde 'confounders' tegelijk wordt gecontroleerd. Het geschatte RR bedraagt dan 1.06(0.99-1.14) voor factor 1 en 1.03(0.92-1.17) voor factor 2. 


\subsection{SAMENVATTING}

De verschillende analyses in dit hoofdstuk hebben de volgende resultaten opgeleverd.

a) Hartinfarctpatiënten slapen in de periode voorafgaande aan hun infarct korter dan personen die om andere redenen in het ziekenhuis waren opgenomen. Dit onderzoek kon echter niet bevestigen dat het hier om een determinant van het hartinfarct gaat. De samenhang tussen korte slaapduur en het hartinfarct kan verklaard worden door bekende risicofactoren zoals roken en AP.

b) De somscores m.b.t. een aantal slaapklachten differentiëren niet duidelijk tussen 'cases' en controles. Dit geldt zowel wanneer slaapklachten middels respectievelijk de slaapklachtenlijst van Jenkins et al. als met de SWEL worden gemeten.

c) Uit de analyses m.b.t. de specifieke slaapklachten uit de SWEL blijkt dat zowel in univariate als in multivariate analyses 'doorslaapproblemen' significant vaker voorkomen bij hartinfarctpatiënten dan bij ziekenhuiscontroles. Dit resultaat kan niet verklaard worden door het voorkomen van de 'confounders' die in deze studie waren opgenomen, evenmin als door slaapapneu. Het is een op zichzelf staande klacht, die het risico op het eerste hartinfarct verhoogt.

d) Tenslotte blijkt ook bij het analyseren van de groepen vragen omtrent insomnia en hypersomnia dat hartpatiënten in de periode voorafgaande aan het infarct vaker problemen hebben met zowel de nachtelijke slaap als met het functioneren overdag dan ziekenhuiscontroles. Het betreft hier met name vermoeidheid overdag. Het voorkomen van deze klachten is echter niet duidelijk te verklaren op grond van lichamelijke en/of geestelijke factoren. Wel geven de partners van de hartpatiënten aan dat hun echtgenoot in de laatste maanden voorafgaande aan het infarct vaker onregelmatig ademden en vaker benauwd uit de slaap wakker werden dan controles. Dit zou kunnen wijzen op slaapapneu, hoewel de betreffende analyses daar niet eenduidig uitsluitsel over geven. 



\section{HOOFDSTUK 6}

\section{NABESCHOUWING}

Dit hoofdstuk bevat de discussie en wordt opgedeeld in een drietal onderdelen, te weten: slaapklachten en het hartinfarct, vitale uitputting en andere variabelen en het hartinfarct, waarbij summier de rol van 'need for control' wordt besproken, terwijl het hoofdstuk wordt afgesloten met enkele aanbevelingen voor toekomstig onderzoek.

\subsection{BEHOORT EEN GESTOORDE SLAAP TO'T DE VOORLOPERS VAN HET HARTINFARCT?}

\section{A. Inleiding}

De centrale vraag van dit onderzoek was of een gestoorde slaap behoort tot de voorlopers van het hartinfarct. Deze vraag kwam allereerst voort uit buitenlandse studies waarin een samenhang tussen slaapklachten en het hartinfaret werd gevonden (Thiel et al., 1973; Thomas et al., 1973; Friedman et al., 1974; Partinen et al., 1982; Wingard \& Berkman, 1983; Siegrist 1985; Koskenvuo et al., 1987). Een tweede aanleiding tot de huidige studie werd gevormd door de resultaten van een prospectief onderzoek bij Rotterdamse Gemeenteambtenaren, waaruit bleek dat zowel problemen met inslapen, doorslapen, als moe wakker worden het risico op een hartinfarct voorspellen (Appels et al., 1987). Van deze drie slaapklachten vormde het gevoel bij het ontwaken moe te zijn de klacht met het grootste voorspellend vermogen. Een ernstige beperking van dit onderzoek was echter dat ieder domein van slaapproblemen slechts door een enkel item werd vertegenwoordigd en dat niet gevraagd werd naar de intensiteit, de duur, en/of de mate waarin dit voor de onderzochten een probleem yormde. Diepgaander en gedetailleerder onderzoek was dus gewenst om dit beeld aan te scherpen. Dit is te meer noodzakelijk omdat nog onbekend is waarom het syndroom van vitale uitputting het risico op een hartinfarct voorspelt. Een van de verklaringsmogelijkheden zou kunnen zijn dat het herstellend vermogen van de slaap in de periode voor het infarct verminderd is. 
Bij het bespreken van de resultaten m.b.t. het voorkomen van slaapklachten zal de volgorde van Hfdst 5 worden aangehouden, te weten: slaapduur, de vragenlijst van Jenkins et al, de Slaap-Waak Ervaring Lijst (SWEL), de groepen vragen m.b.t. insomnia en hypersomnia, en de mogelijke lichamelijke en geestelijke oorzaken van slaapklachten.

\section{B. Slaapduur}

In het onderhavige onderzoek bleek dat infarctpatiënten niet van de ziekenhuiscontroles verschilden in de gerapporteerde slaapduur in de drie maanden voorafgaande aan het infarct (tabel 5.3). Dit is in tegenstelling met de bevinding van Partinen et al. (1982), die vonden dat hartpatiënten vaker langer sliepen, te weten meer dan 9 uur, dan personen zonder hartlijden. Gezien het dwarsdoorsnedekarakter van dit onderzoek, zou dit verschil kunnen worden verklaard doordat personen met een infaret ten gevolge van hun ziekte vaak langer rusten. In het onderhavige onderzoek bleek eerder het tegenovergestelde het geval te zijn: een korte slaapduur, d.w.z. minder dan zeven uur, werd door $23 \%$ van de infarctpatiënten gerapporteerd tegenover $10 \%$ van de controles. Een korte nachtelijke slaapduur bleek met name met AP samen te hangen (tabel 5.5). Een korte slaapduur verhoogde de kans op een infarct met bijna $90 \%$, na controle voor de bovengenoemde 'confounders'. Deze associatie was echter statistisch niet significant, omdat het $95 \%$ betrouwbaarheidsinterval de 1.00 omsloot. Dit betekent dat er niet kan worden geconcludeerd dat een korte slaapduur eenduidig risicoverhogend is.

\section{Slaapklachten}

\section{C.1. De vragenlijst van Jenkins et al.}

In het onderhavige onderzoek bleek de slaapklachtenlijst van Jenkins et al., bestaande uit vier betrekkelijk algemene vragen (tabel 5.6), in psychometrisch opzicht aanvaardbaar te zijn: Cronbach's alpha was .71. In vergelijking met de ziekenhuiscontroles hadden infarctpatiënten in het algemeen een significant hogere somscore $(\mathrm{p}=.03$; tabel 5.8$)$. Dit bleek niet specifiek aan een sterk verschil op een van de vier vragen toegeschreven te kunnen worden (tabel 5.6). Bij stratificatie voor pijn hadden, in de groep zonder pijn, hartinfarctpatiënten een significant hogere somscore vergeleken met ziekenhuiscontroles $(p=.002$; tabel 5.8). Bij controle voor pijn is het geschatte relatieve risico m.b.t. een infarct significant verhoogd $[\mathrm{RR}=1.16(1.05-1.28)$; tabel 5.9]. Dit is echter niet langer het geval na gelijktijdige controle voor leeftijd, pijn, roken, vitale uitputting. AP, en koffie $[R R=1.12(0.96-1.30)$; tabel 5.9). De geschatte relatieve risico's, verbonden met een verandering van een punt op deze lijst, daalden van 
1.16 naar 1.11 na controle voor angineuze klachten en tot 1.10 na controle voor vitale uitputting, terwijl deze niet veranderden na controle voor de overige 'confounders'.

Deze resultaten overziende kan men stellen dat algemene slaapklachten, zoals gemeten met de vragenlijst van Jenkins et al., vaker voorkomen bij mannen die een hartinfarct krijgen dan mannen, die om een andere reden in het ziekenhuis worden opgenomen. Het gaat hierbij echter niet om een sterke risicoindicator. Dat hartinfarctpatiẻnten slaapklachten rapporteren kan verklaard worden omdat zij vaker uitgeputter zijn en vaker angineuze klachten hebben. Dat het verband zwak is kan mogelijk ook veroorzaakt zijn door (1) de relatief eenvoudige wijze waarop dit instrument naar slaapklachten vraagt, of (2) door de opzet van deze studie (zie verder paragraaf E. Mogelijke vormen van 'bias').

\section{C.2. De Slaap-Waak Ervaring Lijst (SWEL)}

Van de infarctpatiënten rapporteerde $39 \%$ een of meerdere slaapklachten in de periode voorafgaande aan de ziekenhuisopname, tegenover $37 \%$ van de ziekenhuiscontroles (tabel 5.10). In de beide groepen patiënten zonder pijn waren deze percentages resp. $34 \%$ en $25 \%$, een verschil dat eveneens niet significant was $(p=.29)$. Bij gebruik van de definities, opgesteld door van Diest et al., moet men dus concluderen dat hartpatiënten voor opname niet meer slaapklachten rapporteerden dan controles.

Uit verdere exploraties bleek echter dat MI-patiënten en controles wel van elkaar verschilden wanneer de frequentie 'soms' in de definitie werd betrokken, maar alleen in de groepen zonder pijn. In deze groepen rapporteerden $51 \%$ van de infarctpatiënten en $35 \%$ van de ziekenhuiscontroles meerdere slaapklachten $(p=.04)$. Toen in een multivariate analyse werd gecontroleerd voor pijn, bleek de somscore op de SWEL een weliswaar gering - maar significant verhoogd - risico op een infarct in te houden, en wel van 35\% (tabel 5.12). Het rapporteren van meerdere slaapklachten vormt dus een risicoindicator voor een toekomstig hartinfarct. Deze bevinding was echter statistisch niet langer significant na controle op $\mathrm{AP}$ (hetgeen een marginale daling van $3 \%$ inhield), en na controle op vitale uitputting. Dit laatste had een aanmerkelijk groter effect: vitale uitputting veroorzaakte een daling van het relatieve risico met $20 \%$.

Deze resultaten overziende, moet men zeggen dat zij slechts een zwak signaal geven dat hartinfarctpatiënten in de drie maanden voorafgaande aan hun ziekenhuisopname meer slaapklachten hadden dan de controles. Dit verschil moet bovendien grotendeels worden toegeschreven aan het feit dat van de toekomstige infarctpatiënten er meer vitaal uitgeput waren, en meer geplaagd werden door (nachtelijke) aanvallen van pijn op de borst.

Bij een analyse van de afzonderlijke slaapklachten van de SWEL werd geconstateerd dat slechts een van de zeven slaapklachten, te weten 'doorslaap'problemen, na gelijktijdige controle voor leeftijd, pijn, roken, vitale uitputting, 
AP, en overmatig koffiegebruik, het risico op het krijgen van een hartinfarct significant verhoogde $[R R=3.26(1.04-10.26)$, tabel 5.15]. Er is hierbij sprake van een 'doorslaap'probleem wanneer de volgende vragen alle positief worden beantwoord: 'Is het voor U een probleem als U 's nachts wakker wordt?' (nogal, erg, heel erg), dan wel 'Als U 's nachts wakker wordt, is het dan een probleem weer in slaap te vallen?' (nogal, erg, heel erg), alsmede 'Kon U meestal weer snel inslapen als U uit Uw slaap wakker was geworden?' (zelden, nooit). Een 'doorslaap'probleem houdt dus zowel in dat men 's nachts vaak wakker wordt en dat men daarna weer moeilijk of in het geheel niet meer inslaapt. Wakker worden omdat men even naar het toilet moet, waarna men weer verder slaapt, wordt dus niet als een 'doorslaap'probleem gezien (van Diest et al., 1989). Dit verschil in codering verklaart waarom het item uit de Maastrichtse Vragenlijst over doorslaapproblemen niet discrimineerde tussen cases en controles. Dit item is te algemeen geformuleerd.

Een onderschatting van het risico op een hartinfarct verbonden met slaapklachten kan veroorzaakt zijn door de vrij strenge definitie die van Diest et al. (1989) gebruikten om aan te geven dat er sprake is van een slaapprobleem. Zij definieerden een slaapprobleem als zodanig wanneer een respondent niet alleen aangaf 'nogal' of 'veel last' van dit probleem te hebben, maar ook dat dit 'vaak' of 'altijd' voorkwam. Verruimt men dit criterium enigermate, namelijk door ook van een slaapprobleem te spreken wanneer dit 'soms' voorkomt, dan stijgt met name bij de infarctpatiënten het aantal personen dat een of meerdere slaapproblemen rapporteert. Bijgevolg differentiëren dan wel een aantal slaapklachten tussen 'cases' en controles die dat voorheen niet deden. Het betreft klachten m.b.t. inslapen $[R R=2.25(1.13-4.48)]$ en doorslapen $[R R=2.46(1.60-6.06)]$ en m.b.t. slaperigheid $[R R=1.93(1.03-3.61)]$ en vermoeidheid overdag $[R R=2.75$ (1.45-5.21)]. Dit zijn wederom aangepaste geschatte RR's, waarbij gecontroleerd werd voor pijn. Zoals hiervoor werd opgemerkt, bleken deze zelfde drie slaapklachten ook in eerder retrospectief (Falger et al., 1988) en prospectief onderzoek (Appels et al., 1987(a)) het risico op een infarct te vergroten.

In deze beide studies bleek vooral 'vermoeidheid overdag' het risico op een hartinfarct duidelijk te verhogen. In het onderhavige onderzoek was dit echter niet het geval, althans wanneer dit werd gemeten middels de vragen uit de SWEL. Analyseert men de vraag over 'vermoeidheid overdag', zoals afkomstig uit de MV, dan blijkt er wel een significant verschil te bestaan tussen hartinfarctpatiënten en controles $\left[\mathrm{Chi}^{2}=7.80\right.$, df $=1 ; \mathrm{p}=.005 ; \mathrm{RR}=2.25(1.22$ 4.18)]. Ook wanneer de definitie in de SWEL wordt verruimd, zoals hierboven aangegeven, blijkt vermoeidheid overdag het risico op het krijgen van een hartinfarct significant te verhogen. Men mag hieruit dus concluderen dat de wijze waarop naar slaapklachten alsmede naar het functioneren overdag gevraagd wordt cruciaal is. 
De vraag is nu: waaraan hecht men meer waarde: aan de strenge of aan de ruimere definitie? In het onderhavige onderzoek werd nagegaan welke specifiek chronische slaapklachten het risico op het krijgen van een hartinfarct verhogen. Verder was het de bedoeling de intensiteit van deze slaapklachten te nuanceren. Beide uitgangspunten werden gerealiseerd door gebruik te maken van de SWEL in de oorspronkelijke vorm. De richtlijnen voor het gebruik van deze lijst werden derhalve gevolgd. Uit het oorspronkelijke psychometrisch onderzoek van de SWEL bleek dat de kwaliteit van de SWEL als 'screenings' instrument voor het opsporen van slaapklachten gemiddeld tot hoog was, echter met uitzondering van vermoeidheid overdag (Van Diest et al., 1989). Dit item is daarom niet opgenomen in de definitieve versie van de SWEL (mondelinge mededeling van van Diest). Ook werd vermoeidheid overdag niet als een specifieke slaapklacht gezien. Dit betekent dat men m.b.t. 'vermoeidheid overdag' als voorspeller van het hartinfarct meer waarde kan hechten aan de uitkomst, zoals gevonden met de MV. In het onderhavige onderzoek blijkt dan dat 'vermoeidheid overdag' vaker voorkomt bij hartinfarctpatiënten dan bij ziekenhuiscontroles en de kans op een infaret significant te verhogen met ruim $200 \%$ (tabel 4.4; item 01).

\section{C.3. Insomnia, hypersomnia en slaapapneu}

Ook bij een indeling in insomnia en hypersomnia werden in het algemeen geen duidelijke verschillen geconstateerd tussen hartinfarctpatiênten en ziekenhuiscontroles. Echter, na stratificatie voor pijn, bleken hartinfarctpatiënten zonder pijn in significante mate gemiddeld vaker insomnia en hypersomnia te rapporteren dan vergelijkbare ziekenhuiscontroles (tabel 5.18). De bijbehorende geschatte relatieve risico's aangepast voor pijn bedroegen resp. 1.04(1.01-1.06) en 1.07(1.01-1.13) per klacht. Bij gelijktijdige controle voor de "confounders" leeftijd, pijn, roken, vitale uitputting, AP en overmatig koffiegebruik verdwijnt dit verhoogde risico.

Ook kan hier weer worden geconcludeerd dat hartinfarctpatiênten vaker insomnia en hypersomnia klachten aangeven omdat zij uitgeputter zijn en vaker AP hebben.

De vragen, waarmee slaapapneu werd gemeten, waren nagenoeg dezelfde als die uit de hier besproken groepen vragen m.b.t. insomnia en hypersomnia. De resultaten waren dan ook grotendeels gelijk. Het risico, samenhangend met een klacht m.b.t. slaapapneu, bleek significant verhoogd bij controle voor pijn en bedroeg 1.05(1.03-1.09). 


\section{Oorzakelijke factoren}

In een aanvullende analyse van vijftien vragen uit de totale groep van slaapklachten, die niet in deze of gene definitie van een specifieke slaapklacht volgens de SWEL waren opgenomen en die mogelijke oorzaken van deze slaapklachten bij cases en controles konden inhouden, kwamen twee karakteristieken significant vaker voor. Het betreft hier de gegevens dat door partners of anderen werd aangegeven dat de hartpatiënt in de laatste maanden, voorafgaande aan het infarct, onregelmatig ademde $[R R=2.29(1.14-4.60)]$, alsmede dat zij vaker benauwd uit hun slaap wakker werden $[R R=2.30(1.10-4.83)]$. Het betreft hier ruwe geschatte relatieve risico's, omdat nadere stratificaties niet werden toegepast.

In het onderzoek werden, tenslotte, geen duidelijke aanwijzingen gevonden dat hartinfarctpatiënten vaker snurkten in de periode voorafgaande aan het infaret, vergeleken met ziekenhuiscontroles. Zesenzeventig procent van de cases $(\mathrm{N}=60)$ en $67 \%$ van de ziekenhuiscontroles $(\mathrm{N}=88)$ gaven aan regelmatig te snurken $\left(\mathrm{Chi}^{2}=1.61\right.$, $\mathrm{df}=1$, NS).

\section{Tussentijdse samenvatting}

Verhoogt een gestoorde slaap nu het risico op een hartinfarct? Na deze studie kan deze vraag bevestigend noch ontkennend worden beantwoord. Sommige bevindingen waren positief. Infarctpatiënten hadden gemiddeld een hogere score op de slaapklachtenlijst van Jenkins, op de clusters insomnia en hypersomnia, en rapporteerden blijkens de SWEL meer doorslaapproblemen in de laatste periode voorafgaande aan hun ziekenhuisopname dan controles. Met uitzondering van de doorslaapproblemen worden de overige klachten voornamelijk verklaard doordat hartinfarctpatiënten uitgeputter waren en vaker AP hadden. Daartegenover staat echter dat er geen duidelijke verschillen werden gevonden tussen de slaapduur van infarctpatiênten en controles, noch in het aantal gerapporteerde slaapklachten, zoals gemeten door de SWEL, noch in zes van de zeven hierin opgenomen specifieke slaapklachten.

Evenals de bevindingen uit een eerder 'case-control' onderzoek (Falger et al., 1988) en prospectief onderzoek (Appels et al., 1987(a)) blijken twee van de drie slaapitems uit de $M V$, wanneer gecontroleerd wordt voor pijn, te discrimineren. Het betreft hier inslaapproblemen, en 's morgens moe en uitgeput wakker worden. 


\section{E. Mogelijke vormen van 'bias'}

Is in deze studie het risico van een gestoorde slaap als voorloper van het hartinfarct bij mannen nu onderschat of overschat? In Hfdst 3.4.2. werden de maatregelen besproken die bij de opzet van dit onderzoek getroffen werden om de schatting van dit risico zo zuiver mogelijk te doen zijn. Hebben deze maatregelen echter voldoende gewerkt?

\section{E.1. Informatie 'bias' en'Recall bias'}

Informatie bias is zoveel mogelijk voorkomen door vooral schriftelijke vragenlijsten te gebruiken.

Een 'case-control' onderzoek, en zeker 'case-control' onderzoek in de medische psychologie, is erg gevoelig voor 'recall bias'. Hartpatiënten, zeker als zij dit van de ene op de andere dag zijn geworden, zoeken welhaast onvermijdelijk een verklaring voor hun ernstige ziekte. Daardoor kunnen zij, na van de ergste schrik te zijn bekomen, sterk interpreterend op het verleden terugkijken en zodoende er een somberder beeld van oproepen dan in werkelijkheid het geval was (Croyle \& Ditto, 1990). Ml-patiënten gaan zich mogelijk meer negatieve gebeurtenissen herinneren, omdat er ziekte op volgde (Jenkins et al., 1979). Het tegenovergestelde kan zich voordoen bij mensen, welke weliswaar een of meerdere negatieve gebeurtenissen hebben doorgemaakt, maar die niet gevolgd werden door een duidelijke ziekte, zoals bij een MI. In dat geval kan de negatieve gebeurtenis of gebeurtenissen gemakkelijk worden vergeten, hetgeen kan leiden tot een onderrapportage bij controles. De verlaagde sensitiviteit en specificiteit die door deze recall bias wordt veroorzaakt, leidt dan vervolgens tot een overschatting van het risico verbonden met deze gebeurtenissen. Door te kiezen voor ziekenhuiscontroles wordt in principe voor het effect van de recente ziekenhuisopname gecontroleerd. Ook deze groep patiënten is immers recent blootgesteld aan een acute opname en velen zullen zich wellicht ook hebben afgevraagd waarom juist zij deze ziekte gekregen hebben. Het blijft echter de vraag of het effect van de kennis en de emoties, dat men zojuist een MI heeft overleefd, gelijk is aan dat van een acute galblaas- of liesbreukoperatie.

Het nadeel van prospectief onderzoek is daarentegen dat mensen tussentijds veranderen, bijvooibeeld slechter kunnen gaan slapen. Iemand die de exposure niet had op het tijdstip van meting, kan deze later wel krijgen. De relatie wordt daarmee dus minder valide, omdat zij minder sensitief is. Daarom kan de schatting van een 'case-control' onderzoek meer valide zijn, dan die welke verkregen wordt in een prospectief onderzoek, omdat de periode waarover men terugblikt veelal korter is dan de periode waarin in prospectief onderzoek wordt vooruitgeblikt. De kans dat het relatieve risico, dat samenhangt met een gestoorde slaap, door recall bias werd onderschat, is in deze studie dus verkleind door zowel te kiezen voor 'case-control' onderzoek als voor (acute) ziekenhuis- 
controles. Het geringe verschil tussen cases en controles wordt daarmee hoogstwaarschijnlijk niet verklaard t.g.v. recall bias.

\section{E.2. Ziekenhuispatiënten als bron van 'bias'}

De keuze van ziekenhuispatiënten als controlegroep kan echter ook geleid hebben tot een onderschatting van het effect, samenhangend met een gestoorde slaap. Zoals opgemerkt in Hfdst 3.3., is bij het samenstellen van de controlegroep zoveel mogelijk uitgegaan van het gegeven dat de ziekte, waarvoor de patiënt was opgenomen, niet zou samenhangen met de belangrijkste onderzoeksvariabele, d.w.z. een gestoorde slaap. Om de kans te verminderen dat deze controles meer slaapklachten zouden uiten dan men zou mogen verwachten, wanneer zij een getrouwe weergave van de source populatie zouden zijn, werd een groot aantal uiteenlopende diagnoses in de controlegroep opgenomen (o.a., liesbreuken, acute ongevallen, maag- en galwegaandoeningen, of botbreuken). In hoeverre is deze opzet nu geslaagd om een controlegroep te vormen die een niet-vertekende weergave van de slaapproblemen in de source populatie geeft?

Uit de analyses bleek, dat $28 \%$ van de ziekenhuiscontroles aangaf vaak last te hebben gehad van pijn of lichamelijk ongemak in de laatste maanden voorafgaande aan de opname, tegenover $14 \%$ van de infarctpatiënten $(p=0.02)$. Veel van deze controles hadden dus mogelijk een gestoorde slaap ten gevolge van hun aandoening. De variabele "pijn" bleek daarom een belangrijke 'confounder'. Men mag echter ook aannemen dat een aantal patiënten zich zorgen maakte over hun ziekte, operatie, of genezingskans, dan wel over hun leven na de behandeling. Uit de betreffende analyses bleek echter dat er geen verschillen waren tussen controles en "cases" m.b.t. het zich zorgen maken bij het inslapen in de maanden voorafgaande aan de ziekenhuisopname $\left(\mathrm{Chi}^{2}=0.002, \mathrm{df}=1\right.$, NS). Geconcludeerd kan worden dat deze factor het geringe verschil tussen cases en controles daarmee niet heeft beïnvloed.

Wanneer men de gegevens uit het onderzoek van van Diest et al. (1989) vergelijkt met die uit deze studie, blijkt er een verschil te zijn tussen de controles in het onderhavige onderzoek en de onderzoeksgroep van van Diest et al. m.b.t. het voorkomen van slaapklachten. Bij van Diest et al gaf $33 \%$ van de onderzochte mannen aan een of meerdere slaapklachten te hebben. In dit onderzoek waren deze percentages voor "cases" en controles resp. $39 \%$ en $37 \%$. De ziekenhuiscontroles rapporteerden dus vaker slaapklachten, vergeleken met "gezonde" mannen van ongeveer dezelfde leeftijd en uit dezelfde regio. Ook blijkt dit voor een aantal specifieke slaapklachten te gelden, te weten, problemen met het inslapen, te vroeg wakker worden, moe opstaan, en slaperigheid en vermoeidheid overdag (Hfdst 2.3). De verschillen zijn echter gering. Een onderschatting van het relatieve risico is daarmee nauwelijks te verklaren door de keuze en samenstelling van de controlegroep. 
Ook m.b.t. het snurken blijkt er een verschil te zijn tussen de controles in het onderhavige onderzoek en de onderzoeksgroep van van Diest et al.. Op de vraag "Weet U via uw partner of anderen dat U snurkt tijdens Uw slaap?" bleek dat in dezelfde populatie, te weten volwassen mannen uit Zuid-Limburg $(\mathrm{N}=451)$, waaruit zowel de infarctpatiënten als de controles voortkomen, $59 \%$ $(\mathrm{N}=265)$ van de mannen aangeeft geregeld te snurken (van Diest at al.,1989). Hieruit kan worden geconcludeerd dat de controlegroep niet exact weergeeft hoe deze "exposure"variabele is verdeeld in de "source"populatie. Dit kan hebben geleid tot een onderschatting van het relatieve risico verbonden met snurken.

\section{Samenvatting}

Deze studie heeft geen ondubbelzinnig bewijs kunnen leveren voor de stelling dat een gestoorde slaap het risico op een hartinfarct vergroot, ook al werden er enkele aanwijzingen gevonden. Met name lijken chronische doorslaapproblemen het risico op een infarct te verhogen, meer in het bijzonder problemen die men heeft bij het opnieuw inslapen, nadat men wakker is geworden. Vermoeidheid overdag, hoewel niet een typisch slaapprobleem (Hfdst. 2.2.), blijkt eveneens significant vaker voor te komen bij hartinfarctpatiënten dan bij controles.

\subsection{VITALE UITPUTTING ALS VOORLOPER VAN HET HARTINFARCT}

\section{A. Discussie}

Zoals uiteengezet in Hfdst 4.3 bleek vitale uitputting een duidelijke risicoindicator voor het hartinfarct te vormen. In vergelijking met een score in het laagste tertiel van de MV hing een score in het hoogste tertiel, die het meest representatief is voor vitale uitputting, samen met een geschat relatief risico van 3.75(1.66-8.48), na controle voor pijn (tabel 4.6). De. schatting uit het onderhavige onderzoek komt goed overeen met het risico, zoals gevonden in prospectief onderzoek (Appels et al., 1989), waarbij het risico werd geschat op 3.92, over een totale "follow-up" periode van vier jaar. In hetzelfde onderzoek bleek echter ook dat het risico, samenhangend met vitale uitputting, vooral hoog was in het begin van deze periode. Waarschijnlijk is de schatting in de onderhavige studie aan de lage kant, omdat ziekenhuiscontroles ten gevolge van hun aandoening mogelijk een verhoogde score op de MV hebben, en bijgevolg niet. representatief zouden kunnen zijn voor het voorkomen van vitale uitputting in de "source"populatie. In eerder retrospectief onderzoek bedroeg het risico, samen- 
hangend met een MV-score in het hoogste tertiel, in de vergelijking met ziekenhuiscontroles 4.29, na controle op AP (Falger, 1989).

Uitgaande van een "cut-off point" score van 13.5 bleek $67 \%$ van de infarctpatiënten uitgeput te zijn, wat betekent dat men tenminste zes klachten op de MV had geuit. Deze score komt overeen met de mediaanscore van de controlegroep. Omdat deze groep vanwege pijn en andere mogelijke consequenties van hun aandoeningen een vrij hoge gemiddelde MV-score had, is deze mediaanwaarde relatief hoog te noemen. Zou men de tertielnormen aanhouden van het prospectieve onderzoek bij Rotterdamse Gemeenteambtenaren, dan zou $82.3 \%$ van alle infarctpatiënten uitgeput genoemd moeten worden, te weten, $40.5 \%$ "matig uitgeput" en $41.8 \%$ "uitgeput". Dit totale percentage komt nauwkeurig overeen met de gegevens uit eerder onderzoek (Falger, 1989). In dit onderzoek bedroeg het aantal uitgeputte MI-patiënten $82 \%$, bij een mediaanwaarde van 8.0.

In het onderhavige onderzoek werd er, evenals in het eerdere 'casecontrol' onderzoek (Falger, 1989), een relatie gevonden tussen Type A gedrag en vitale uitputting. Zij die zowel uitgeput als Type A waren, hadden een sterk verhoogd risico op een hartinfarct, te weten, 8.67 (3.11-24.19) (tabel 4.8). In het eerder genoemde onderzoek bleek er echter geen significante interactie tussen beide variabelen te bestaan (Falger, Schouten \& Appels, 1993, in bewerking). Ook in het onderhavige onderzoek werden gelijke bevindingen gevonden.

\section{B. Mogelijke vormen van 'bias'}

\section{B.1. Informatie 'bias'}

In hoeverre zijn deze resultaten beinvloed door informatie bias? Zoals eerder opgemerkt, zijn "case-control"studies gevoelig voor informatie bias. Hartpatiënten gaan meestal op zoek naar een verklaring voor het gebeuren. "Stress" vormt daarbij een vaak gehanteerde verklaringsbron (NHS, 1983). Overschatten infarctpatiënten daarmee de mate van vitale uitputting in de periode voor het hartinfarct? Deze kans lijkt relatief klein. Op het moment van het onderzoek was bij een breed publiek niet bekend dat gevoelens van vitale uitputting het risico op een hartinfarct kunnen verhogen. Op zoek naar een verklaring komt men meestal uit bij een of meerdere (ingrijpende) gebeurtenis(sen), en niet bij een toestand van vermoeidheid.

Was de rapportage omtrent vitale uitputting ook valide, kortom, overdreven de onderzochte hartpatiënten niet? Om na te gaan hoe betrouwbaar de antwoorden van deze patiënten op de MV waren, werd daarom ook aan 48 echtgenotes gevraagd om deze lijst zo in te vullen, zoals zij dachten dat hun man deze bij waarheidsgetrouwe rapportage zou hebben ingevuld. Uit een vergelijking van de gemiddelde scores bleek dat deze niet betekenisvol van elkaar afweken. 
De gemiddelde score van de patiênten was $20.8(\mathrm{SD}=13.2)$, terwijl het gemiddelde van de schatting door hun echtgenotes $19.7(S D=14.4)$ bedroeg. De product-moment correlatiecoefficient was 0.85 . Het beeld dat de betreffende mannen gaven over de mate van vitale uitputting voor hun infarct correspondeerde dus goed met het beeld dat hun partners hiervan schetsten. Natuurlijk bestaat de mogelijkheid dat echtparen na het hartinfarct (uitvoerig) gesproken hebben over de mentale toestand voor het infarct. Het kan dus zijn dat de hoge correlatiecoefficient de feitelijke correspondentie overschat. Uit gesprekken met de infarctpatiënten en echtgenotes thuis kwam echter de stellige indruk naar voren dat de echtgenotes goed hadden waargenomen dat hun man voor het infarct zo "anders" was geworden, lustelozer, vlugger geprikkeld, en zonder energie.

\section{B.2. Ziekenhuiscontroles als bron van 'bias'}

Er blijken een aantal ziekenhuiscontroles te zijn, te weten, patiënten die last van pijn en lichamelijk ongemak hadden en patiënten die aangaven angineuze klachten te hebben, die een extreem hoge score op de MV vertoonden. Dit is begrijpelijk, omdat in deze vragenlijst naar klachten wordt gevraagd die eveneens kunnen optreden bij pijn. Wat dat betreft is deze lijst mogelijk niet specifiek genoeg. De klachten die men rapporteert m.b.t. vitale uitputting dienen immers niet verklaard te kunnen worden ten gevolge van pijn of lichamelijk lijden. In het onderhavige onderzoek was het mogelijk om achteraf te controleren voor pijn en lichamelijk ongemak, waardoor er een zuiverder schatting m.b.t. de samenhang tussen vitale uitputting en het hartinfarct werd verkregen. Ziekenhuiscontroles vormen dus geen mogelijke bron van bias, indien het mogelijk is om voor pijn en lichamelijk ongemak te controleren. Toekomstig onderzoek zou daar dus rekening mee moeten houden. Gezien het feit dat MI- patiënten en ziekenhuiscontroles beiden een recente ziekenhuisopname hebben meegemakt, waardoor ze in principe over een gelijkwaardig referentiekader beschikken, gaat de voorkeur uit naar ziekenhuiscontroles boven buurtcontroles.

\section{Samenvatting}

Ook in het onderhavige 'case-control' onderzoek bleek vitale uitputting een duidelijke risicoindicator van het hartinfaret te zijn. Dit viel voornamelijk toe te schrijven aan de items die handelen over prikkelbaarheid en opvliegendheid, en over vermoeidheid overdag. Pijn blijkt ook hier weer een belangrijke. confounder te zijn. In dit onderzoek, waarin het verschil tussen "cases" en controles zoveel mogelijk was geminimaliseerd, discrimineerden twee van de drie slaapklachten uit de MV na controle voor pijn. In het onderhavige onderzoek bleek er opnieuw een duidelijke relatie te bestaan tussen vitale uitputting en Type A gedrag. Wanneer beide factoren tesamen voorkomen, is het risico op 
een hartinfarct groter dan wanneer zij afzonderlijk aanwezig zijn. Het verdient aanbeveling hiernaar verder onderzoek te doen.

\section{3. 'NEED FOR CONTROL' ALS VOORLOPER VAN HET HARTINFARCT}

Naast slaapklachten en vitale uitputting werd in dit onderzoek ook de rol van 'immersion' in de ontstaansgeschiedenis van het hartinfarct onderzocht. In het onderhavige onderzoek bleek 'immersion' te differentieren tussen werkende "cases" en controles $(t=2.02 ; \mathrm{df}=90, \mathrm{p}=0.05)$. Dit betekent dat hartinfarctpatienten het handhaven van controle over gebeurtenissen hadden opgegeven (Siegrist 1984, 1985, 1987(b)). Zij hebben mogelijk ingezien verkeerde inschattingen te hebben gemalakt en geven als gevolg daarvan de strijd op. Ook werd een positieve samenhang gevonden tussen 'immersion' en vitale uitputting $(r=0.37$, $\mathrm{p}=0.00$ ). Controleert men voor beide variabelen dan blijkt Vitale Uitputting een sterkere risicoindicator te zijn.

In hoeverre 'immersion' voorafgaat aan vitale uitputting, of andersom, kan niet uit deze gegevens worden opgemakt. Het lijkt echter waarschijnlijk dat 'immersion' aan vitale uitputting voorafgaat. Uit vele gesprekken met MIpatiënten en hun partners bleek dat in de periode voorafgaande aan het hartinfarct, de patiënten met name in hun werk gebeurtenissen hadden meegemaakt, waarmee ze onvrede hadden. Het was voor hen moeilijk of onmogelijk geworden om dit gevoel los te laten, hetgeen gepaard ging met onlustgevoelens, prikkelbaarheid, en vermoeidheid. Een voorbeeld mag dienen als illustatie.

Dhr. X, getrouwd, 2 kinderen, is onderhoudsmonteur bij de Gemeente M. Hij heeft zich altijd voor de volle $100 \%$ ingezet voor zijn werk. Als er hem iets werd gevraagd, deed hij dit ook onmiddellijk. Dan makt dhr. $\mathrm{X}$ een aantal maanden voorafgaande aan zijn infarct op zijn werk het volgende mee. Een goede kennis van hem kwam te overlijden en hij vroeg verlof om naar de begrafenis te kunnen gaan. Dit werd hem echter geweigerd. Hij kon dit niet verkroppen. "lk heb me altijd goed ingezet voor het werk, dan vraag ik eens iets, en krijg ik nul op het request". "Ik ben altijd te goed geweest, maar ik ben niet meer zo gek". Dhr. X geeft aan dat mensen in zijn directe omgeving vonden dat hij veranderd was in de periode voorafgaande aan het hartinfarct. Daarbij viel vooral op dat hij prikkelbaarder en opvliegender was geworden. Zelf geeft hij aan dat hij toen erg moe was, maar ondanks dat had hij 's nachts moeite om goed te kunnen slapen. 
In het onderhavige onderzoek bleek dat slaapproblemen significant vaker voorkomen bij personen met een hogere score op de factor 'immersion' zoals dhr. X.. Het uiteindelijk opgeven van de strijd geeft vooral problemen bij het opnieuw inslapen, nadat men wakker is geworden. Een slechte nachtrust kan vervolgens aanleiding geven tot slecht functioneren overdag.

\subsection{ALGEHELE SAMENVATTING EN AANBEVELINGEN VOOR TOEKOMSTIG ONDERZOEK}

Onderzoeken van uiteenlopende aard hebben aangetoond dat hartinfarctpatiēnten vaker slaapproblemen hadden in de periode voorafgaande aan het infarct dan andere personen. Het gaat hierbij om problemen met het inslapen en het doorslapen, om het 's morgens moe en uitgeput wakker worden, en om 's morgens moe wakker worden en opstaan. Ook werd er een samenhang gevonden tussen slaapduur en het hartinfarct en snurken en het hartinfarct, in die zin dat een lange slaapduur en snurken het risico op het hartinfarct verhogen.

De nadruk van het onderhavige onderzoek ligt bij de slaapklachten als onderdeel van vitale uitputting. De belangrijkste vraag van dit 'case-control' onderzoek was of een gestoorde slaap het risico op een eerste hartinfarct bij volwassen mannen verhoogt. Om deze vraagstelling te kunnen beantwoorden werkten 79 hartpatiënten en 132 ziekenhuiscontroles aan het onderzoek mee. Deze laatsten waren terzelfdertijd in hetzelfde ziekenhuis opgenomen als de hartpatiënten. Teneinde te controleren voor de invloed van pijn werden mannen die opgenomen waren vanwege chronische maligne pijnlijke aandoeningen buiten het onderzoek gelaten. Hartpatiënten en controles waren gematched op leeftijd, in leeftijd variërend tussen 35 - 65 jaar. Alleen mannen kwamen in aanmerking voor deelname aan het onderzoek.

Gaande het onderzoek werd duidelijk dat de factor pijn en lichamelijk ongemak, waarmee weliswaar vooraf bij de selectie van patiënten rekening werd gehouden, een belangrijke 'confounder' was. Hiervoor diende achteraf in de statistische analyses gecontroleerd te worden. In de discussie werd daarom mede over de gegevens na controle voor pijn gerapporteerd.

Bij dit onderzoek werden de volgende vragenlijsten m.b.t. slaapklachten gebruikt: (a) De slaapklachtenlijst van Jenkins; (b) de Slaap-Waak Ervaring Lijst (SWEL); en (c) een itempool waarmee slaapklachten gemeten kunnen worden.

Een aantal variabelen, te weten: Leeftijd, roken, angina pectoris (AP), Type A gedrag, en vitale uitputting en factoren die met slaapklachten kunnen samenhangen, maar niet altijd een duidelijk verband met hart- en vaatziekten vertonen (d.w.z., overmatige koffieconsumptie, pijn en lichamelijk ongemak 
anders dan AP, en medicijngebruik) werden eveneens in het onderzoek opgenomen teneinde voor hun mogelijke invloed op de voornaamste vraagstelling te kunnen controleren. Deze variabelen werden in kaart gebracht middels: (d) de Rose Questionnaire ter bepaling van AP; (e) de Maastrichtse Vragenlijst (MV) ter meting van vitale uitputting; en ( $f$ ) een vragenlijst waarmee de frequentie van roken, en koffie-, alcohol- en medicijngebruik werd bepaald. In deze studie werd tevens ( $\mathrm{g}$ ) het Gestructureerde Interview ter bepaling van Type A gedrag afgenomen.

De redenen voor het ontstaan van vitale uitputting zijn nog niet volledig bekend. Een mogelijke verklaring zou zijn dat de mate van "need for control" bij hartpatiënten kan leiden tot depressieve gevoelens en uitputting. De periode voorafgaande aan het infarct zou zich door "fear of losing control" kenmerken. Na een lange vruchtloze strijd zou de periode voorafgaande aan het infarct worden gekenmerkt door controle-verlies. Het onderzoek naar "need for control" is gericht op de cognitieve en perceptuele gevolgen van een dominante behoefte om controle te handhaven. Met name type A gedrag wordt gekenmerkt door een sterke behoefte om controle te handhaven. Hun cognitieve systeem zou op dusdanige wijze zijn ontwikkeld dat voortdurend verkeerde inschattingen worden gemaakt. Eisen vanuit de omgeving worden daarbij onderschat en eigen "coping" mechanismen overschat. Deze grote inspanning wordt "vigor" genoemd. Wanneer dit uiteindelijk leidt tot toenemend controleverlies en zelfs tot het staken van de strijd, wordt dit "immersion genoemd. Beide concepten vitale uitputting en "need for control" zullen eveneens worden onderzocht. In verband met het onderzoek naar 'need for control' werd eveneens gevraagd naar al dan niet werken in de periode voorafgaande aan de ziekenhuisopname en de hierbij ervaren werklast. Deze werd gemeten met (h) de Marburgse vragenlijst, een vertaling van de 'need for control' lijst van Siegrist et al. In de studie was, tenslotte, (i) een vragenlijst opgenomen waarmee het voorkomen van recente 'life-events' werd vastgesteld.

Uit de meeste analyses komt naar voren dat hartpatiënten in de periode voorafgaande aan hun eerste infarct meer slaapproblemen hebben en overdag slechter functioneren dan patiënten die om andere redenen in het ziekenhuis waren opgenomen. De verschillen tussen beide groepen patiënten bleken meestal erg klein te zijn en vaak slechts marginaal significant. Alleen doorslaapproblemen verhoogden duidelijk de kans op een infarct. Ook bleek dat vermoeidheid overdag, hetgeen echter geen typische slaapprobleem is, een verhoogd risico op een infarct inhield.

Evenals in andere studies bleek vitale uitputting een belangrijke risicoindicator voor het hartinfarct te vormen. Er is sprake van vitale uitputting wanneer een individu niet alleen klaagt over ongewone vermoeidheid en 
energieverlies, maar ook het gevoel heeft verslagen te zijn, terwijl vermoeid en uitgeput wakker worden eveneens een belangrijk kenmerk is. Vitale uitputting gaat voorts vaak samen met een toename in prikkelbaarheid en opvliegendheid, en met libidoverlies. Depressieve symptomen kunnen samenhangen met vitale uitputting, maar dit is niet noodzakelijk. Een belangrijk kenmerk is tenslotte dat het gevoel van eigenwaarde niet is aangetast en schuldgevoelens afwezig zijn. Slaapproblemen vormden van het begin af aan een belangrijk onderdeel van het construct vitale uitputting. Daarbij ging het om inslaapproblemen, doorslaapproblemen en soms moe of uitgeput wakker worden. De aanleiding voor dit onderzoek was een verdere exploratie van deze klachten. Daaruit kwam verrassend naar voren dat vooral doorslaapproblemen een belangrijke voorspeller van het hartinfarct zijn. Het belang van deze doorslaapproblemen, te weten, niet opnieuw kunnen inslapen nadat men wakker is geworden, bleek vooral bij analyse van de verschillende vragen over slaapproblemen en niet bij de analyse van de Maastrichtse Vragenlijst. Het construct zou daarbij aangevuld kunnen worden met een nadere operationalisatie van doorslaapproblemen.

Een analyse van de afzonderlijke items, die tesamen het construct vitale uitputting vormen, wees uit dat met name de items over toegenomen prikkelbaarheid een sterk discriminerend vermogen hadden, d.w.z. veel vaker door infarctpatiënten werden gerapporteerd dan door de controles. Combineert men deze bevindingen, dan komt het beeld naar voren van een 'hyper-arousal' ten gevolge van recente ergernis, die het voor toekomstige infarctpatiënten moeilijk of haast onmogelijk maakt weer in slaap te komen, nadat zij eenmaal wakker zijn geworden. In de late nacht of vroege ochtend lijkt dan meer activatie te ontstaan, die waarschijnlijk fysiologische en neurohormonale consequenties heeft. Deze activatie vindt plaats tijdens de periode waarin de meeste REMslaap optreedt, tussen 4 en 7 uur 's ochtends (Roffwarg, 1979). Het is in deze periode dat de meeste infarcten beginnen, om enige uren later manifest te worden (Hammond, 1964; Roffwarg, 1979; Mancia \& Zanchetti, 1980).

Recent onderzoek vanuit het deelproject (van Diest, et al., 1993) heeft tevens uitgewezen dat de slaap van uitgeputte maar 'gezonde' volwassenen wordt gekenmerkt door de afwezigheid/vermindering van de delta-slaap. Dit vormt hiermee een aanvullende fysiologische bevinding die suggereert dat het herstellende vermogen van de slaap bij uitgeputte personen verminderd is. In het onderhavige onderzoek zou dit tot uitdrukking kunnen komen in klachten m.b.t. vermoeidheid overdag en slecht of in het geheel niet kunnen doorslapen 's nachts. Deze klachten vormen meestal geen reden om hulp in te roepen van een huisarts of specialist. Ze kunnen weliswaar langere tijd voorkomen (d.w.z. 3 maanden, de maximale periode waarnaar in dit onderzoek werd gevraagd), maar dit geschiedt vaak op een incidentele basis: dan weer wel en dan weer niet. Echter, in combinatie met pijn op de borst en verschijnselen van vitale uitputting kunnen dergelijke doorslaapproblemen voor de huisarts een belangrijk 
signaal vormen dat een patiënt met dit complex van klachten en problemen een (sterk) verhoogd risico op een hartinfarct loopt.

Uit de meta-analyses van Booth-Kewley et al.(1987) naar de samenhang van type A gedrag en hart- en vaatziekten, kwam verrassend naar voren dat depressie een betere voorspeller was dan type A gedrag en bovendien onafhankelijk was van type A gedrag. Sinds dit artikel zijn er enkele studies gepubliceerd over de samenhang tussen slaapklachten, depressie en het hartinfarct en daaruit blijkt dat slapeloosheid voorspelt omdat ze samenhangt met depressie (Freedland, 1992; Carney e.a., 1990). Onderzoek wat daarop voorborduurt vindt vergelijkbare resultaten. Sommige items van de MV, met name item 14: "Hebt U de laatste tijd weleens het verlangen voelen opkomen het bijltje erbij neer te leggen?"; en item 17: "Voelde U zich gedeprimeerd of teneergeslagen?" kunnen ook worden geinterpreteerd als aanwijzingen van een sombere en depressieve grondstemming. Deze items hingen samen met een significant tweevoudig verhoogd risico op een infarct (tabel 4.4.). Daarnaast bleken in de analyses m.b.t. de redenen voor doorslaapproblemen, dat personen met deze problemen vaker aangeven verdrietige of sombere gevoelens te hebben. Het ging hierbij om een gezamelijke analyse bij hartinfarctpatiënten en ziekenhuiscontroles. Deze gegevens rechtvaardigen een nadere exploratie van een mogelijke samenhang tussen slaapklachten en VU enerzijds en slaapklachten en depressie anderzijds.

Tenslotte wanneer gekeken wordt naar beide constructen "vigor" en "immersion" dan blijkt dat "immersion" eveneens significant vaker voor te komen bij hartinfarctpatiënten dan bij controles. Ook 'immersion' gaat samen met doorslaapproblemen. De toekomstige infarctpatiënt klaagt over problemen met opnieuw inslapen, nadat men wakker is geworden. Als gevolg van een slechte nachtrust kan men overdag niet goed functioneren. Er is sprake van toegenomen prikkelbaarheid en opvliegendheid en er wordt geklaagd over vermoeidheid.

Vruchíbare gebieden van verder onderzoek lijken daarom de vragen op welke wijze chronische ergernis en toegenomen prikkelbaarheid van invloed zijn op doorslaapproblemen, en langs welke mechanismen deze combinatie de kans op een infaret vergroten. Ook zoụ hierbij de rol van Type A gedrag kunnen worden betrokken, gelet op het opnieuw bevestigde gegeven dat Type A gedrag, in combinatie met vitale uitputting, een sterk verhoogd risico op een infarct inhoudt. Tevens lijkt het nuttig te onderzoeken hoe 'immersion', vitale uitputting, en doorslaapproblemen zich ten opzichte van elkaar verhouden. Is het zo dat er een verandering plaats vindt in de tijd? Is er allereerst sprake van 'immersion', hetgeen vervolgens leidt tot vitale uitputting en tot doorslaapproblemen? Of zijn het drie verschillende aspecten die tesamen het risico op het infarct verhogen? Longitudinaal onderzoek is het beste in staat om bovenstaande vragen te kunnen beantwoorden. 


\section{SUMMARY}

Cross-sectional, retrospective, and prospective studies have shown that sleep problems are risk indicators for coronary artery disease (CAD). Those sleep problems are: problems with initiating and maintaining sleep, exhaustion on final awakening and getting up, sleep duration that deviates from the usual 7 to $8 \mathrm{hrs}$. of sleep, and heavy snoring.

In this case-control study, sleep problems were primarily studied as a major component of vital exhaustion. It has been shown that vital exhaustion is an important risk indicator for myocardial infarction (MI) in adult males and females. Vital exhaustion is primarily characterized by complaints about unusual fatigue and loss of energy, increased irritability, and a feeling of being defeated. Being tired on awakening also constitutes a major complaint in this respect. Another hallmark of vital exhaustion is loss of libido. Other depressive feelings may be present as well but are not necessarily reported in order to be assessed as being vitally exhausted. Finally, guilt feelings and loss of self-esteem appear to be absent.

The main research question of this case-control study was: Do sleep problems associate with MI ? In all, 79 MI-patients and 132 hospital controls from the same hospitals were studied. The controls were hospitalized at about the same time as the cases were. All cases and controls were age-matched males who were between 35 and 65 years of age. In order to control for the influence of pain and physical discomfort other than chest pain, those males who had been hospitalized because of chronic malignent pain disorders were excluded. It occurred during the investigation that pain and physical discomfort were, however, still reported more often by controls and, thus, constituted a confounder. Therefore, in the final analyses, pain and physical discomfort other than chest pain were controlled for.

To answer the research question, various questionnaires were employed, namely: a) the Jenkins sleep questionnaire; b) the Sleep-Wake Experience List; and c) a list containing a number of other sleep questions.

In order to control for confounders, other variables were measured as well, namely: age, smoking, angina pectoris (AP), Type A behavior, and vital exhaustion. Moreover, questions about coffee and alcohol consumption, pain and physical discomfort other than chest pain, and medicine use were included. These variables were measured by means of the following questionnaires: d) the Rose Questionnaire for AP; e) the Maastricht Questionnaire about vital 
exhaustion ( 24 instead of 21 items); and $\mathrm{f}$ ) a life styles questionnaire about smoking, coffee and alcohol consumption, and medicine use. Type A behavior was assessed by means of the Structured Interview.

The reasons why individuals may become vitally exhausted are still not fully understood. Perhaps the awareness of MI-patients' misinterpretations of their coping behavior ("need for control") can lead to feelings of vital exhaustion and of depression. Both constructs, vital exhaustion and need for control, will be investigated in this study.

It is well known that Type A behavior is characterized by the need to continuously control personal environments as much as possible. In the last few months prior to MI, many (Type A) MI-patients have reported a "fear of losing control". During this period, they overestimate environmental demands and underestimate their personal coping capabilities (i.e., "immersion").

Like in many other studies, Type A behavior occurred significantly more often in MI-patients than in controls. Moreover, it was associated with a shorter sleep duration.

Most of the analyses from the present study show that MI-patients complained about poor sleep at night and malfunctioning during the day in the period before $\mathrm{Ml}$, compared to hospital controls. The differences between both groups were rather small, however, and were mostly marginally significant. Problems with staying asleep, in particular having trouble going back to sleep again after waking up during the night, and feeling tired during the day significantly increased the risk of MI.

As in previous case-control studies, vital exhaustion as assessed by means of the Maastricht Questionnaire (MQ) was a strong risk indicator for MI. It was also observed that vital exhaustion was a stronger risk indicator than Type A behavior, something which had been found previously in our research group. Moreover, the risk associated with having become an exhausted Type A, was larger than with either vital exhaustion or Type A behavior.

Item-analysis of the MQ showed that the three items about increased irritability discriminated best (i.e., the significantly elevated odds ratios ranged from 4.2 to 3.2). It may be thought that MI- patients have become hyperaroused as a result of a recent event; therefore, they may have trouble falling asleep again after awakening during the night. It may be speculated that in those patients in the period prior to their MIs, more physiological and neurohormonal activation occurred late in the evening or early morning than in same-aged healthy subjects. In particular, this activation may take place in the period when most REM-sleep occurs, that is, between 4 and 7 o'clock in the morning. In this episode, most Mls become manifest.

Recent research has found that the sleep of exhausted healthy males is characterized by a decrease in delta sleep, compared to non-exhausted 
subjects. Therefore, the revitalizing capacity of sleep has become impaired in exhausted subjects. In the present case-control study this was represented by the findings that MI-patients reported being tired during the day and had trouble staying asleep. Such complaints appear not enough reason, however, to seek help from a physician. They have been present for a longer period of time, but appeared to be rather infrequent. Thus, in combination with chest pain of recent onset, these complaints may be an important indicator of increased risk of near-future MI.

In a meta-analysis by Booth-Kewley \& Friedman (1987) it appeared that depression was a stronger risk indicator for MI than Type A behavior. Since this publication, a number of studies have been published in which the associations between sleep problems, depression, and MI was studied. Insomnia constitutes part of depression and, therefore, it may be associated with MI. The patients (both MI and hospital controls) from the present study who reported trouble staying asleep, complained more often about feeling sad and mournful than those who did not report sleep problems. Those results suggest that more research is needed about the associations between sleep problems and vital exhaustion and depression.

Finally, in the present study, MI-cases were more often "immersed" than hospital controls. "Immersion" goes together with trouble staying asleep. As reported above, future patients complain about trouble falling asleep again after waking up during the night in the period before MI. As a result of poor sleep, their day time functioning becomes disturbed, which is expressed by feeling tired and by increased irritability. Future research, in particular longitudinal studies, may answer the question how chronic irritability may inhibit one's staying asleep and which underlying mechanisms may increase the risk of MI. 



\section{LITERATUUR}

Alonzo, A., Simon, A., Feinleib, M. Prodromata of myocardial infarction and sudden death. Circulation 1975, 52, 1056-1062.

Appels, A. Een overzicht van het onderzoek naar de rol van psychosociale factoren in het ontstaan van het hartinfarct. Tijdschrift voor Geneeskunde 1978, 18, 1153-1163.

Appels, A. Psychological prodromata of myocardial infarction and sudden death. Psychotherapy \& Psychosomatics 1980, 34, 187-195.

Appels, A., Jenkins, C.D., Rosenman, R. Coronary-prone behavior in the Netherlands: A cross-cultural validation study. Journal of behav. med. 1982, 5, 8390.

Appels, A. Psychologische aspecten van het hartinfarct. In Appels A (red) Psychologische risicofactoren voor het hartinfarct. Alphen a/d Rijn, Stafleu 1983, 1460.

Appels, A. Capita Selecta: gedrag en het hartinfaret. Nederlands Tijdschrift voor de Geneeskunde 1985, 129, 436-440.

Appels, A., Höppener, P., Mulder, P. A Questionnaire to assess premonitory symptoms of myocardial infarction. International Journal of Cardiology 1987, 17, 15-24.(a)

Appels, A., Vos, Y. de, Diest, R., van et al. Are sleep complaints predictive of future myocardial infarction?. Activitas Nervosa Superior (Praha) 1987, 29, no 2.(b)

Appels, A., Mulder, P. Excess fatigue as a precursor of myocardial infarction. European Heart Journal 1988, 9, 758-764.

Appels, A., Mulder, P., Höppener, P. Een prospectieve studie over vitale uitputting als voorloper van het hartinfarct en andere ernstige aandoeningen. Nederlands Tijdschrift voor de Psychologie 1989, 44, 122-137.

Appels, A. Mental precursors of myocardial infarction. Britisch Journal Psychiatry $1990,156,465-471$.

Aserinsky, E. \& Kleitman, N. Regurlarly occuring periods of eye motility and concomitant phenomena during sleep. Science 1953, 118, 273-274.

Axelson O, Flodin U, Hardell L. A comment on the reference series with regard to multiple exposure evaluations in a case-referent study. Scandinavian Journal of Work Environment and Health 1982, 8, suppl 1: 15-19.

Axelson $\mathrm{O}$. The case-referent study - some comments on its structure, merits and limitations. Scandinavian Journal of Work Environment and Health 1985, 114, 207-213. 
Balter M, Bauer M. Patterns of prescribing and use of hypnotic drugs in the United States. In A. Clift (ed) Sleep disturbances and hypnotic drug dependence I. New York NY, Excerpta Medica 1974, 261-291.

Bengtsson, C.,Hallstrom, T., and Tibblin, G. Social factors, stress experience and personality traits in women with ischaemic heart disease, compared to a population sample of women, Acta Med. Scand. Suppl. 1972, 549, 82-92.

Berlin R, Libowitz G, Diaz M et al. Sleep disorders in a psychiatric consultation service. American Journal of Psychiatry 1984, 141, 582-584.

Bixler, E.O., Kales, J.D., Scharf,M.B., Kales, A, Leo, L.A. Incidence of sleep disorders in medical practice: a physician survey: In: Sleep Research (Edited by Chase M.H., Mitler, M., Walter, P.L.) pp 160, Los Angeles, UCLA BIS/BRI 5,1976.

Bixler, E.O., Kales, J.D., Soldates, C.R. et al. Physical and mental health correlates of insomnia Los Angeles metropplitan area survey. Sleep Res. 1977, 6, 139

Bixler, E., Kales, A., Soldatos, C. Sleep disorders encountered in medical practice: a national survey of physicians. Journal of Behavioral Medicine 1979, 6, 1-6. (a)

Bixler, E., Kales, A., Soldatos, C. et al. Prevalence of sleep disorders in the Los Angeles metropolitan area. American Journal of Psychiatry 1979, 136, 1257 1262. (b)

BMDP Statistical Software (1988), Los Angeles: University of California Press.

Booth-Kewley, S., Friedman, H. Psychologic predictors of Heart disease: A quatitative review. Psychol Bull 1987, 101, 343-359.

Brand, R., Rosenman, R. Sholtz, R. et al. Multivariate prediction of coronary heart disease in the Western Collaborative Group study compared to the findings of the Framingham Study. Circulation 1976, 53, 348-355.

Bruhn, J., Chandler, B., Miller, M. et al. Social aspects of coronary heart disease in two adjacent, ethically different communities. American Journal Medical Sciences 1966, 56, 1493-i506.

Burack B. The hypersomnia-sleep apnea syndrome: its recognition in clinical cardiology. American Heart Journal 1984, 107, 543-548.

Carney, R., Freedland, K., Jaffe, A. Insomnia and Depression Prior to myocardial infarction. Psychosomatic Medicine 1990, 52, 603-609.

Cirignotta F, D'Alessandro R, Partinen M et al. Prevalence of sleep apneas and heay snorers' disease. Sleep Research 1988, 17, 162.

Coleman R, Zarcone V, Redington D et al. Sleep-wake disorders in a family practice clinic. In M Chase, D Kripke, P Walter (eds) Sleep Research. 9, 192, UCLA BIS/BRI Los Angeles 1980.

Coleman R, Roffwarg H, Kennedy S et al. Sleep-wake disorders based on polysomnographic diagnosis - a national coopterative study. JAMA 1982, 247, 997 1003. (a)

Coleman R, Sassin J, Schmidt H et al. Sleepiness and periodic movements in sleep. Sleep 1982, 5, 191-202. (b) 
Coleman R. Diagnosis, treatment and follow-up of about 8000 sleep-wake disorder patients. In C Guilleminault, E Lugaresi (eds) Sleep-wake disorders: natural history, epidemiology and long term evolution. New York NY, Raven Press 1983, 87-97.

Cornfield, J. A method of estimating comparative rates from clinical data. Applications to cancer of the lung,breast and cervix. Journal of Natl. Cancer Inst, 195I, $11,1269-1275$.

Crisp A, Queenan M, D'Souza M. Myocardial infarction and the emotional climate. Lancet 1984, $i, 616-619$.

Croyle, R., Ditoo, P. Illness cognition and behavior: An experimental approach, $J$ behav Med 1990, 13, 31-52.

Deedwania,P., Swiryn,S., Dhingra, R., Rosen, K. Nocturnal Atrioventricular Block as a Manifestation of Sleep Apnea syndromen. Chest 1979, 1976, 3, 319-321.

De Diana, I. Two stochastic sleep quality scales for self-rating of subjects' sleep. Sleep Reviews 1976, 5, 101.

Dicicco, B., Looper, J., Waldhorn, R. Sleep disorders in medical illness. Psychiatric Medicine 1987, 4, 133-148.

Diest, R. van, Milius, H., Markusse, R. et al. De slaap-waak ervaring lijst. Tijdschrift Sociale Gezondheidszorg 1989, 67, 343-347.

Diest, R. van. Subjective Sleep characteristics as coronary risk factors, their association with type A behavior and vital exhaustion. Journal of psychomatic Research $1990,34,4,415-426$.

Diest, R. van, Appels, A. Sleep physiological characteristics of exhausted males. Accepted for publication in Psycho som med, 1993

Diest, R. van. Sleep and Vitale Exhaustion: their relationship with cardiovascular disease. Thesis Maastricht, 1993.

Engel, G. A life setting conductive to illness. Bulletin Menninger Clinic 1968, 32, 355-365.

Falger, P. Life-span development and myocardial infarction: an epidemiological study. Maastricht, Rijksuniversiteit Limburg 1989, academisch proefschrift.

Falger,P, Schouten, E., Appels, A., Nelissen-de Vos, Y. Sleep complaints, behavioral characteristics and vital exhaustion in myocardial infarction cases. Psychology and Health 1988, 2, 231-258.

Feinstein, A. Clinical biostatistics. St.Louis MO, Mosby 1977.

Floderus, B. Psychosocial factors in relation to coronary heart disease and associaled risk factors. Stockholm (S), Stockholm University 1974, Ph.D. thesis:

Fraser, G. Sudden death in Auckland. Australian New Zealand Journal Medicine 1978, 8, 490-499.

Freedland, K., Carney, R., Lustman, P. et al. Major depression in coronary artery disease patients with vs without a Prior History of depression. Psychosomatic medicine 1992, 54, 416-421.

Friedman, M., Rosenman, R. Association of a specific overt behavior pattern with blood and cardiovascular findings. JAMA I959, I69, 1286-1295. 
Friedman, G., Ury, H., Klatsky, A. et al. A psychological questionnaire predictive of myocardial infarction: results from the Kayser-Permanente epidemiologic study of myocardial infarction. Psychosomatic Medicine 1974, 36, 327-343.

Gillum, R., Feinleib, M., Margolis, J., et al. The Pre-hospital Phase of Acute Myocardial infaretion and Sudden Death. Preventive Medicine 1976, 5, 408413.

Glass, D. Behavior patterns, stress and coronary heart disease. Hillsdale: Laurence Erlbaum 1977.

Graaf, W. de. Huisarts en slacpgedrag. Waarneming omtrent slaapgedrag van patiënten in een huisartspraktijk. Lisse, Swets \& Zeitlinger 1984.

Guilleminault, C., Tilkian, A., Dement, W. The sleep apnea syndromes. Annual Review Medicine 1976, 27, 465-484.

Guilleminault, C., Cuminskey, J., Dement, W. Sleep apnea syndrome. Recent advances. Advances Internal Medicine 1980, 26, 347-372.

Guilleminault, C., van der Hoed, J., en Mitler,M. Clinical overview of the sleep apnea syndromes. In: Sleep Apnea syndromes, C. Guilleminault and Dement, WC (Eds), Alan R Liss, New York, 1978.

Guilleminault, C., Conolly, S., Winkle, R. Cardiac arrhythmia and conduction disturbances during sleep in 400 patients with sleep apnea syndrome. American Journal Cardiology 1983, 52, 490-494.

Hartmann, E. Sleep. In: Comprehensive Textbook of Psychiatry (3rd ed.). A. Freedman, H.Kaplan \& B. Sadock (Eds.). Baltimore: Williams \& Wilkins, $1980,165-177$.

Hammond E. Some preliminary findings on physical complaints from a prospective study of 1.064.004 men and women. American Journal Public Health 1964, 54, 11-23.

Hauri, P. A cluster Analysis of Insomnia. Sleep 1983, 6(4), 326-338.

Haynes, S. \& Matthews, K. Review and methodological critique of recent studies on Type A behavior and cardiovascular disease. Annals of Behavioral Medicine $1988,10,47-59$.

Hennekens, C.H., Willet, W., Rosner, B. et al. Effects of beer, wine and liquor in coronary deaths. JAMA 1979, 242, 1973-1978.

Hetta, J., Almqvist, H., Agren, G., et al. Prevalence of sleep disturbances and related symptoms in a middle-aged Swedish population. In: Sleep. W Koella, E Ruther, H Schulz (eds.) Stuttgart, Gustav Fischer Verlag 1985, 373-376.

Hicks, R., Allen, J., Armogida, R, et al, Reduction in sleep duration and Type A behavior. Bulletin Psychonomic Society 1980, 16, 109-110.

Hicks, R., Pellegrini, R. Sleep problems and Type A-B behavior in college students. Psychological Reports 1982, 51, 196.

Hyyppa, M., Kronholm, E. Sleep movements and poor sleep in patients with non specific somatic complaints - affective disorders and sleep quality. Journal Psychosomatic Research 1987, 31, 631-637. 
Ibrahim, M. (ed.) The case-control study: consensus and controversy. Journal Chronic Diseases 1979, 32, 1-44.

International classification of diseases, 9th revision, clinical modification. (ICD-9. $\mathrm{CM})$. WHO center for classification of diseases for North America. National Center for Health Statistics. Ann Arbor MI, Edwards Brothers Inc. 1978.

Issa, F., Sullivan, C. Alcohol, snoring and sleepapnea. Journal Neurol. Neurosurg. Psychiat. 1982, 45, 353-359.

Istvan, J., Matarazzo, J. Tobacco, alcohol and caffeine use: A review of their interrelationships. Psychological Bulletin 1984, 95, 301-326.

Jenkins, C.D. Psychological and social precursors of coronary disease. New England Journal Medicine 1971, 284, 244-255, 307-317.

Jenkins, C.D. Recent evidence supporting psychologic and social risk factors for coronary disease. New England Journal Medicine 1976, 294, 1033

Jenkins, D., Hurst, M., Rose, R. Life changes: Do people really remenber? Arch Gen Psychiat 1979, 36, 379-384.

Jenkins, C.D. Psychological and behavioral factors from: prevention of coronary heart disase. N. Kaplan en J. Stamler (eds.). Philadelphia: Saunders, 1983, Hoofdstuk 8, 98-112.

Jenkins, C.D., Stanton, B., Niemcryk, S. et al. A scale for the estimation of sleep problems in clinical research. Journal Clinical Epidemiology 1988, 41, 313321 .

Jick, H., Vessey, M. Case-control studies in the evaluation of drug-induced illness. American Journal Epidemiology 1978, 107, 1-7.

Johnson, L., Tepas, D., Colquihoun, W., et al. Biological rhythms, sleep and shift work. (Weitzman E.D. (series ed)): Advances Sleep Research, New York NY, SP Medical \& Scientific Books vol.7, 1981.

Kales, A., Caldwell, A., Preston, T., et al. Personality patterns in insomnia. Archives General Psychiatry 1976, 33, 1128-1134.

Kales, A., Soldatos, C., Kales, J. Taking a sleep history. American Family Physician $1980,10,101-108$.

Kales, J., Kales, A., Soldatos, C. et a!. Night terrors: clinical characteristics and personality patterns. Arch. Gen. Psychatr. 1980, 37, 1413-1417.

Kales J, Soldatos C, Kales A. Diagnosis and treatment of sleep disorders. In: Treatment of mental disorders. J Greist, J Jefferson, R Spitzer (eds.), New York NY, Oxford University Press 1982, 473-500.

Kales, A., Kales, J., Soldatos, C. Insomnia and other sleep disorders. Medical Clinics North America 1982, 66, 971-991.

Kales, A., Caldwell, A., Soldatos, C. et al. Biopsychobehavioral correlates of insomnia: II pattern specificity and consistency with the Minnesota Multiphasic Personality Inventory. Psychosomatic medicine 1983, 45, 341-356.

Kales, A., Kales, J. Evaluation and treatment of insomnia. New York NY, Oxford University Press 1984. 
Kales, J., Kales, A., Bixler, E., et al. Biopsychobehavioral correlates of insomnia: $\mathrm{V}$ clinical characteristics and behavioral correlates. American Journal Psychiatry 1984, 141, 1371-1376.

Kales, A., Soldatos, C., Kales, J. Sleep disorders: insomnia, sleepwalking, night terrors, night mares and enuresis. Annals Internal medicine 1987, 106, 582592.

Kapuniai,L., Andrew, D., Crowell, D., Pearce, J. Identifying sleep apnea from selfreports. Sleep 198911 (5), 430-436.

Karacan, I., Thornby, J., Anch, M., et al. Dose-related sleep disturbances induced by coffee and caffeine. Clinical Pharmacology Therapeutics 1976, 20, 682-689. (a)

Karacan, I., Thornby, J., Anch, M., et al. Prevalence of sleep disturbance in a primarily urban Florida county. Social Science Medicine 1976, 10, 239-244. (b)

Karacan, I., Thornby, J.I., Williams, R.L.. in: Sleep/wake disorders: natural history epidemiology and long-term evolution, Guilleminault, C., Lugaresi, E. (Eds.) Raven Press, New York, 37-60, 1983.

Kavanagh, T., Shephard, R.J. The immediate antecedents of myocardial infarction in active men. C M A journal, july 7, 1973, 109, 19.

Kinlen, L. Incidence and presentation of myocardial infarction in an English community. British Heart Journal 1973, 35, 616-622.

Klatsky, A., Friedman, G., Siegelaub, A. Medical history questions predictive of myocardial infarction. Results from the Kaiser-Permanente epidemiologic study of myocardial infarction. Journal Chronic Diseases 1976, 29, 683-696.

Kleinbaum, D., Kupper, L., Morgenstern, H. Epidemiologic research: principles and quantitive methods. New York NY, Van Nostrand Reinhold 1982.

Koskenvuo, M. Cardiovascular stress and sleep. Annals Clinical Research 1987, 19, $110-113$.

Koskenvuo, M., Kaprio, J., Telakivi, T., et al. Snoring as a risk factor for ischaemic heart disease and stroke in men. British Medical Journal 1987, 294, 16-19.

Kripke, D., Simons, K., Garfunkel, L., et al. Short and long sleep and sleeping pills is increased mortality associated. Archives General Psychiatry 1979, 36, 103116.

Kuller, L., Cooper, M., Perper, J. Epidemiology of sudden death. Archives Internal Medicine 1972, 129, 714-719.

Kuller, L. Prodromata of sudden death and myocardial infarction. Advances Cardiology 1978, 25, 61-72.

Lavie, P. Sleep habits and sleep disturbances in industry workers in Israel: main findings and some characteristics of workers complaining of excessive daytime sleepiness. Sleep 1981, 4, 147-158.

Lavie, P. Incidence of sleep apnea in a presumably healthy working population. A significant relationship with excessive daytime sleepiness. Sleep 1983, 6, 312318. 
Lebovitz, B.Z., Shekell, R. B., Ostfeld, A.M., Paul, O. Prospective and retrospective psychological studies of coronary heart disease. Psychosomatic Medicine 1967, 29, 265-272.

Lilienfeld A, Lilienfeld D. Foundations of epidemiology. New York NY, Oxford University Press 1980.

Lugaresi, E., Cirignotta, F., Coccagna, G., et al. Some epidemiological data on snoring and cardiocirculatory disturbances. Sleep 1980, 3, 221-224.

Lugaresi, E., Cirignotta, F., Coccagna, G. et al. Snoring and obstructive apnea syndrome. American Journal Medicine 1982, 73(3), 317-321.

MacMahon, B., Pugh, T. Epidemiology: principles and methods. Boston MA, Little Brown 1970.

Manfredi, R., Ugontzas, A., Kales, A. An update on sleep disorders. Bulletin Menninger Clinic 1989, 53, 250-273.

Mantel, N. Chi-square tests with one degree of freedom: Extensions of MantelHaenszel procedure. Journal of the American Statistical Association 1963, 58, 690-700.

Mantel, N., \& Haenszel, W. Statistical aspects of the analysis of data from retrospective studies of disease. Journal of Natl. Cancer Inst. 1959, 22, 719.748.

Mantel, N., Brown, C. \& Byar, D. Test for homogeneity of effect in an epidemiologic investigation. American Journal of epidemiology 1977, 106, 125-129.

Mancia, G., Zanchetti, A. Cardiovascular regulation during sleep. In: Orem, J., and Barnes, C.D. (Eds.) Physiology in sleep. Academic Press, New York, 1980, $1-55$.

Matschinger, H., Siegrist, J., Siegrist, K. et al. Type A as a coping career $=$ towards a methodological re-definition. In: T Schmidt, T Dembroski, G Blümchen (eds.), Biological and psychological factors in cardiovascular disease. SpringerVerlag Heidelberg 1986.

Matthews, K., Haynes, S. Type A behavior pattern and coronary disease risk: update and critical evaluation. American Journal Epidemiology 1986, 123, 923-960.

McGhie, A., Russell, S. The subjective assessment of normal sleep patterns. Journal Mental Sciences 1962, 108, 642-654.

Miettinen, O. Estimability and estimation in case-control series. American Journal of Epidemiology 1976, 103, 225-235.

Miettinen, $\mathrm{O}$. The "case-control" study: valid selection of subjects. Journal Chronic Diseases 1985, 7, 543-548.

Miettinen, O. Theoretical Epidemiology: Principles of Occurence Research in Medicine. New York, NY: Wiley, 1985.

Miles, L. Sleep questionnaire and assessment of wakefulness (SQAW). In: C Guilleminault (ed.), Sleeping and waking Disorders:" indications and techniques. Menlo Park CA, Addison-Wesley 1982, 383-413. 
Mondini, S., Zucconi, M., Cirignotta, F., et al. Snoring as a risk factor for cardiac and circulatory problems: an epidemiological study. In: C Guilleminault, E Lugaresi (eds.), Sleep-wake disorders: natural history, epidemiology and long term evolution. New York NY, Raven Press 1983, 99-105.

Monroe, L., Marks, P. MMPI differences between adolescent poor and good sleepers. Journal Consult. Clin. Psychology 1977, 45, 151-152.

Moore-Ede, M., Sulzman, F., Fuller, C. The clocks that time us: physiology of the circadian timing system. Cambridge MA, Harvard University Press 1982.

Morin, C., Kwentus, J. Area review: sleep disorders. Behavioral and pharmacological treatments for insomnia. Annals Behavioral Medicine 1988, 10(3), 91-100.

Nixon, $P$. The human function curve, with special reference to cardiovascular disorders. Pt I and Pt II. Practitioner 1976, 217, 765-770, 935-944.

Nixon, P., Hugh, J., Bethell, M. Preinfarction ill health. American Journal Cardiology $1974,33,446.449$.

Norton, P. Dunn E. Snoring as a risk factor for disease: an epidemiological survey. British Medical Journal 1985, 291, 630-632.

Orth-Gomèr, K., Edwards, M., Erhardt, L., et al. Relation between ventricular arrhythmias and psychological profile. Acta Medica Scandinavica 1980, 207, 31-36.

Paffenbarger, R., Wolfe, P.A., Notkin, J. et al. Chronic disease in former college students. I. Early prcursors of fatal coronary heart disease. American Journal Epidiomology 1966, 83, 314.-328.

Parkes, J. Sleep and its disorders. Philadelphia PA, Saunders 1985.

Partinen, M., Putkonen, P., Kaprio, J., et al. Sleep disorders in relation to coronary heart disease. Acta Medica Scandinavica 1982, suppl 660, 69-83.

Partinen, M., Alihanka, J., Lang, H. et al. Myocardial infarction in relation to sleep apneas. Sleep Research 1983, 12, 272

Partinen, M., Eskelinen, L., Tuomi, K. Epidemiology of insomnia: environmental factors. In: W Koella, E Rüther, H Schulz (eds.), Sleep "84. Stuttgart, Gustav Fischer Verlag 1985, 42-44.

Pearce, N., Checkoway, H. Case-control siudies using other diseases as controls: problems of excluding exposure-related diseases. American Journal Epidemiology 1988, 127, no 4.

Peter, J., Siegrist, T., Podszus, J., Mayer, K., et al. Prevalence of sleep apnea in healthy industrial workers. Klin. Wochenschr. 1985, 63, 807-811.

Raphael, K. Recall bias: Aproposal for assessment and control. International Journal of Epidemiology 1987, 16 (no 2), 167-170.

Rechtschaffen, A., \& Kales, A. A manual of standardized terminology, techniques, and scoring system for sleep stages of human subjects. Washington DC. Public Heakih Service, US Government Printing office 1986.

Reynolds, C., Shubin, R., Coble, P., et al. Diagnostic classification of sleep disorders: implications for psychiatric practice. Journal Clinical Psychiatry 1981, 42, 296-299. 
Rissanen, V., Romo, M., Siltanen, P. Premonitory symptoms and stress factors preceding sudden cardiac death from ischaemic heart disease. Acta Medica Scandinavica 1978, 204, 389-396.

Roffwarg, H. Association of Sleep Disorders Centers (1979). Diagnostic classification of sleep and arousal disorders. 1st edition. Sleep 1979, 2, 1-137.

Rose, G., Blackburn, H., Gillum, R., Prineas, R. Cardiovascular survey methods. Geneva: World Health Organization, Monograph series no. 56 (2nd ed.) 1982.

Rosenman R., Friedman, M. Association of specific behavior pattern in women with blood and cardiovascular findings. Circulation 1961, 24, 1173.

Rosenman, R., Friedman, M.,Straus, R., er al. Apredictive study of coronary heart disease. The Western Collabirative Group srtudy. JAMA 1964, 189, 15-22.

Rosenman, R.H., Jenkins, C.D., Brand, R.J., Friedman, M. et al. Coronary heart disease in the Western Collaborative Group Study: Final follow-up eperience of 8,5 years. Journal of Am.Med.Ass. 1975, 233, 872-877.

Rosenman, R.H., Brand, R.J., Sholtz, R.I., Friedman, M. Multivariate prediction of coronary heart disease during 8.5 years follow-up in the collaborative group study. American Journal Cardiology 1976, 37, 903-10

Rosenman, R. (1978) The interview method of assessment of coronary-prone behavior pattern. In: T. Dembroski, S. Weiss, J. Shields, S. Haynes and M. Feinleib (eds.), Coronary prone behavior. New York: Springer.

Rosenman, R. Psychosomatic risk factors and coronary heart disease. Bern, Huber 1983.

Rothman, K. Modern epidemiology. Boston MA, Little Brown 1986.

Rothman, K., \& Boice,J. (1982) Epidemiologic analysis with a programmable calculator. Boston: Epidemiological resources.

Sackett, D. Bias in analytic research. Journal Chronic Diseases 1979, 32, 51-63.

Sawyer, D., Julia, H., Turin, A. Caffeine and human behavior: arousal, anxiety and performance effects. Journal Behavioral Medicine 1982, 5, 4.15-439.

Schlesselman, J. Sample size requirement in cohort and cse-control studies of disease. Am.Journal of Epidemiology 1974, 99, 381-384.

Schlesselman, J. Case-control studies. New York NY, Oxford University Press 1982.

Seidel, W., Dement, W. Sleepiness in insomnia: evaluation and treatment. Sleep 1982, 5, 182-190.

Siegel, S. Nonparametric Statistics. For the behavioral sciences. Mc Graw - Hill book Company, Inc., N.Y. 1956.

Siegrist, J., Dittmann, K., Rittner, K., Weber, I. The social context of active distress in patients with early myocardial infarction. Social Science Medicine 1982, 16, 443-453.

Siegrist J. Threat to social status and cardiovascular risk. Psychotherapy Psychosomatics 1984, 42, 90-96.

Siegrist J. Cardiovascular risk in the framework of a coping career - theoretical model and epidemiologic evidence. Proceedings, 8 th world congress of psychosomatic medicine, Chicago IL, 1985. 
Siegrist J, Peter H. Schlafstörungen und kardiovasculäres Risiko. Medizinische Klinik $1986,81,429-432, \mathrm{nr} 12$.

Siegrist, J. Sleep disturbances and cardiovascular risk: bio-psychosocial related Disorders and International Diseases (Edited by Peter J.H., Podszus T. von Wichert P.) Berlin: Springer, 1987, 173-182.(a)

Siegrist, J. Impaired quality of life as a risk factor in Cardiovascular Disease. Journal of Chron.Dis. 1987, 40, 6, 571-578.(b)

Siegrist, J., Peter, H., Himmelmann, J., Geyer, S. Erfahrungen mit einem Anamnesebogen zur diagnostik der Schlafapnoe. Prax. Klin. Pneumol.1987, 41, 357363.(c)

Siegrist, J., Peter, H., Junge, J., Cremer, P., Seidel, D. Low status control, high effort at work and ischaemic heart disease: prospective evidence from blue collar men. Soc. Sci. Med. 1990, 31, 1127-1134.

Smith, A., Pearce, N., Callas, P. Cancer case-control studies with other cancers as controls. International Journal Epidemiology 1988, 17, no 21.

Soldatos, C., Kales, J., Bixler, E., et al. Cigarette smoking associated with sleep difficulty. Science 1980, 207, 551-553.

Stowers, M. Warning symptoms before myocardial infaretion. British Heart Journal $1970,32,833-838$.

Taasan, V., Block, A., Boysen, P., et al. Alcohol increases sleep apnea and oxygen saturation in a-symptomatic men. American Journal Medicine 1981, 71, 240245.

Telakivi, T., Partinen, M., Koskenvuo, M., et al. Periodic breathing and hypoxia in snorers and controls: validation of snoring history and association with blood pressure and obesity. Acta Neurologica Scandinavica 1987, 76, 69-75. (a)

Telakivi, T., Partinen, M., Koskenvuo, M., et al. Snoring and cardiovascular disease. Comprehensive Therapy 1987, 13, 53-57. (b)

Thiel, H., Parker, D., Bruce, T. Stress factors and the risk of myocardial infarction. Journal Psychosomatic Research 1973, 17, 43-57.

Thomas, C., Greenstreet, R. Psychobiological charateristics in youth as predictors of five disease states: suicide, mental illness, hypertension, coronary heart disease and tumor. Johns Hopkins Medical Journal 1973, 132, 16-43.

Thoresen, C.E. Burnett, K.F., Rosekin, M.R. et al, Chronic stress and reported sleep disturbances. Sleep Res. 1980, 9, 250.

Vanhala, K. Psychological risk factors related to coronary heart disease. Monogr. Psychiatr. Fenn. 1979, 9.

Verhagen, F., Nass, C., Appels, A., et al. A cross validation of the A/B typology in the Netherlands. Psychotherapy psychosomatics 1980, 34, 178-186.

Vollmer, M. The obestruvtive sleep apnea syndrome: Pathophysiology, Diagnosis and treatmet. Indiana Medicine. December 1987, 80, 12.

Waller P, Bhopal R. Is snoring a cause of vascular disease ? an epidemiological review. Lancet 1989, 21, 1, 143-6. 
Wang, J., Miettinen, O. Occupational mortality studies, principles of validity, Scandinavian Journal Work Environment Health 1982, 8, 153-158.

Welstein, L., Dement, W., Redington, D., et al. Insomnia in the San Francisco Bay Area: a telephone survey. In: Sleep-wake disorders: natural history, epidemiology, and long-term evolution, Guilleminault, C., Lugaresi, E. (eds.). Raven Press 1983 NY: 73-85.

Westermeyer, J. Alcohol and other drug abuse and sleep behavior disorder. (letter). JAMA 1987, 258, 323.

Wiggens, C., Schmidt-Nowara, W., Coultas, D. et al. Comparison of Self- and Spouse Reports of Snoring and other Symptoms Associated with Sleep Apnea Syndrome. Sleep 1990, 13(3), 245-252.

Williams, R., Karacan, I. Sleep disorders, diagnosis and treatment. New York NY, Wiley 1978.

Williams, R. Psychological factors in coronary artery disease: Epidemiologic evidence. Circulation 1987, 76, Monograph 6, ! 117-123.

Williams, R., Karacan, I., Moore, C. Sleep disorders, diagnosis and treatment, 2nd́ edition. New York NY, Wiley Interscience 1988.

Wingard, D., Berkman, L. Mortality risk associated with sleeping patterns among adults. Sleep 1983, 6, 102-107.

Wingard, D., Berkman, L., Brand, R. A multivariate analysis of health-related practices: a nine year mortality follow-up of the Alameda County Study. American Journal Epidemiology 1982, 116, 765-775.

Wolf, S. The end of the rope. The role of the brain in cardiac death. Canadian Medical Association Journal 1967, 97, 1022-1025.

Zomer, J., Peled, A., Rubin, H. et al. Mini Sleep Questionnaire for screening large populations for EDS complaints. In: W Koella, E Rüther, H Schulz (eds.), Sleep 1984, 467-470, Gustav Fischer Verlag Stuttgart New York. 


\section{BIJLAGE 1. \\ TOEGEZONDEN BRIEF}

Geachte heer,

Aan Rijksuniversiteit Limburg te Maastricht wordt al verschillende jaren uitgebreid onderzoek gedaan naar hart- en vaatziekten. In samenwerking met het ziekenhuis proberen we de factoren te ontdekken die een rol spelen bij het krijgen van een hartinfarct. Zijn deze factoren bekend dan kan eerder ingegrepen worden zodat een hartinfarct voorkomen kan worden.

Om dit onderzoek mogelijk te maken hebben wij de medewerking nodig van verschillende mensen namelijk

- hartinfarctpatiênten

- mensen die om andere redenen dan een hartinfarct opgenomen waren in het ziekenhuis.

Aangezien U Uw toestemming hebt gegeven mee te werken aan ons onderzoek stuur ik U zoals afgesproken was de vragenlijsten. Wilt $U$ deze zo nauwkeurig en volledig mogelijk invullen. De antwoorden zullen strikt vertrouwelijk en anoniem behandeld worden.

De ingevulde vragenijijten kom ik dan bij $\mathrm{U}$ ophalen. Tevens wil ik $\mathrm{U}$ dan nog een en ander vragen naar aanleiding van de antwoorden die U gegeven hebt. ik zal $\mathrm{U}$ telefonisch laten weten wanneer ik de vragenlijsten kom ophalen.

Bij voorbaat dank voor Uw medewerking. 


\section{BLJLAGE 2. ITEMPOOL SLAAPKLACHTEN}

De tijd die u nodig heeft voor het invullen van deze vragenlijst is ongeveer 20 minuten. Voor het onderzoek is het erg belangrijk dat u geen vragen overslaat.

Eerst volgen een aantal algemene vragen.

1. Wat is uw leeftijd

2. Werkte $u$ in de drie maanden voorafgaande aan uw infarct?

3. Indien u werkte, had u onregelmatige werktijden?

4. Had u méér dan 1 lange slaapperiode per 24 uur?

5. Had $\mathrm{u}$ in de 3 maanden voorafgaande aan uw infarct een vaste tijd om naar bed te gaan?

6. Had $\mathrm{U}$ in de $\mathbf{3}$ maanden voorafgaande aan uw infarct een vaste tijd om op te staan?

7. Hoe vindt $u$ dat $u$ in de 3 maanden voorafgaande aan uw hartinfarct geslapen heeft?

8. Hoelang vindt $u$ dat $u$ in de 3 maanden voorafgaande aan uw hartinfarct geslapen heeft?

9. Tijdens welk gedeelte van de dag was $u$ in de afgelopen 3 maanden yoorafgaande aan uw infarct het meest actief?

10. Hoeveel uren sliep $\mathrm{U}$ meestal in de afgelopen 3 maanden voorafgaande aan uw infarct?
.... jaar

ja ? neen

ja ? neen

ja ? neen

ja ? neen

ja ? neen

0 goed

0 matig

0 slecht

0 te lang

0 normaal

0 te kort

0 begin

0 midden

0 eind

0 ?

0 minder dan 5 uur

0 minder dan 6 uur

0 minder dan 7 uur

0 minder dan 8 uur

0 minder dan 9 uur

0 meer dan 9 uur 
Beschouwt u zichzelf als een

$\begin{array}{ll} & 0 \text { lichte slaper } \\ & 0 \text { normale slaper } \\ & 0 \text { diepe slaper } \\ & \\ \text { helemaal een heel nogal } \\ \text { niet beetje erg erg }\end{array}$

12. Had $\mathrm{u}$ in de 3 maanden voorafgaande aan uw infarct problemen met in slaap komen?

0

$\begin{array}{lll}0 & 0 & 0\end{array}$

13. Voelde $u$ het als een probleem als $u$ in de 3 maanden voorafgaande aan uw infarct 's nachts wakker werd?

$\begin{array}{llll}0 & 0 & 0 & 0\end{array}$

14. Als u 's nachts wakker werd in de afgelopen 3 maanden voorafgaande aan het hartinfarct, had u dan problemen om weer in slaap te komen?

$\begin{array}{llll}0 & 0 & 0 & 0\end{array}$

15. Had $\mathrm{u}$ in de 3 maanden voorafgaande aan uw infarct problemen met moeilijk wakker worden en opstaan?

$\begin{array}{lll}0 & 0 & 0\end{array}$

16. Had u in de 3 maanden voorafgaande aan uw infaret problemen met te vroeg wakker worden?

$0 \quad 0 \quad 0$

17. Had u last van vermbeidheid overdag in de 3 maanden voorafgaande aan uw infarct, zonder u slaperig te voelen?

0

$0 \quad 0 \quad 0$

18. Had $u$ in de 3 maanden voorafgaande aan uw infarct last van vermoeidheid bij het opstaan ook al had u genoeg geslapen?

19. Indien u zich vermoeid voelde bij het

(ichamelijk opstaan, hoe uitte zich dit?

G geestelijk

0 beide

O niet van toepassing 
Nu volgen een aantal vragen over hoe $u$ in de 3 maanden voorafgaande aan uw infarct ingeslapen bent.

20. Viel u meestal op een vaste tijd in slaap? ja ? neen

21. Zijn er de afgelopen tijd periodes geweest dat u steeds later kon inslapen? ja ? neen

22. Deed $u$ speciale dingen om in slaap te komen? ja ? neen

23. Indien u speciale dingen deed, kunt u dan aangeven wat $\mathrm{u}$ deed?

24. Hoelang duurde het meestel voor $u$ in slaap 0 minder dan 5 minuten viel?

0 minder dan 20 minuten

0 minder dan 60 minuten

0 langer dan 60 minuten

25. Hoelang lag u langer dan gewoonlijk wakker?

0 minder dan 1 keer per maand

01 tot 4 keer per maand

0 meer dan 1 keer per week

nooit zelden soms vaak altijd

26. Als u wilde gaan slapen, viel u dan snel in slaap?

$\begin{array}{lllll}0 & 0 & 0 & 0 & 0\end{array}$

27. Hoevaak maakte u zich zorgen voor het inslapen?

$\begin{array}{lllll}0 & 0 & 0 & 0 & 0\end{array}$

28. Hoevaak had $u$ voor het inslapen last van een verdrietig of somber gevoel?

$\begin{array}{lllll}0 & 0 & 0 & 0 & 0\end{array}$

29. Hoevaak voelde u zich angstig voor het inslapen?

$\begin{array}{lllll}0 & 0 & 0 & 0 & 0\end{array}$

30. Hoevaak was u bang niet in slaap te kunnen vallen?

$\begin{array}{lllll}0 & 0 & 0 & 0 & 0\end{array}$

31. Hoevaak kon u voor het inslapen uw benen onmogelijk stilhouden?

$\begin{array}{lllll}0 & 0 & 0 & 0 & 0\end{array}$


32. Hoevaak had u bij het inslapen levendige droomachtige beelden?

$\begin{array}{lllll}0 & 0 & 0 & 0 & 0\end{array}$

33. Hoevaak had $u$ last van pijn of lichamelijk ongemak?

$\begin{array}{lllll}0 & 0 & 0 & 0 & 0\end{array}$

34. Hoevaak had $\mathrm{u}$ bij het inslapen het gevoel dat u zich niet meer kon bewegen?

$\begin{array}{lllll}0 & 0 & 0 & 0 & 0\end{array}$

Nu volgen een aantal vragen over hoe $u$ in de 3 maanden voorafgaande aan uw infarct geslapen heeft.

35. Bent u de laatste 3 maanden voorafgaande aan uw infarct steeds langer gaan slapen?

ja ? neen

36. Weet u via uw partner of anderen dat u snurkt tijdens uw slaap?

ja neen

37. Weet u via uw partner of anderen dat u overmatig met uw benen beweegt tijdens uw slaap?

ja ? neen

38. Weet u via uw partner of anderen dat u onregelmatig ademt tijdens uw slaap?

ja neen

39. Was u de 3 maanden voorafgaande aan uw hartinfarct regelmatig langer dan 5 minuten uit bed?

ja ? neen

40. Hoevaak werd u meesta! wakker tijdens uw slaap-

0 nooit periode?

01 toi 3 keer

04 tot 6 keer

0 meer dan 6 keer

41. Wanneer werd u meestal wakker tijdens uw

0 begin slaapperiode? (u kunt bij deze vraag meer antwoorden geven).

0 midden

0 eindl

0 niet van toepassing

42. Indien u wakker werd, hoelang bleef $\mathrm{u}$ dan

0 minder dan $5 \mathrm{~min}$. meestal wakker?

0 minder dan $20 \mathrm{~min}$.

0 minder dan $60 \mathrm{~min}$.

0 meer dan $60 \mathrm{~min}$.

43. Indien u wakker werd, hoevaak stond u dan

0 nooit meestal op?

01 tot 3 keer

04 tot 6 keer

0 meer dan 6 keer 
44. Hoevaak bent $u$ in de 3 maanden voorafgaande aan uw infarct tijdens uw slaap volledig wakker geworden?
0 minder dan 1 keer per maand

01 tot 4 keer per maand

01 tot 4 keer per week

0 bijna elke nacht

45. Had u problemen met een te lichte of

0 geen problemen te diepe slaap?

0 te lichte slaap

0 te diepe slaap

nooit zelden soms vaak altijd

46. Kon u weer snel inslapen nadat u wakker was geworden?

$\begin{array}{lllll}0 & 0 & 0 & 0 & 0\end{array}$

47. Hoevaak had u last van nachtmerries? $0 \begin{array}{llllll}0 & 0 & 0 & 0 & 0\end{array}$

48. Hoevaak werd U wakker uit een droom? $0 \quad 0 \quad 00000$

49. Hoevaak werd u tijdens uw slaap wakker door pijn of prikkeling in de benen?

$\begin{array}{lllll}0 & 0 & 0 & 0 & 0\end{array}$

50. Hoevaak had $u$ het benauwd als u uit uw slaap wakker werd?

$\begin{array}{lllll}0 & 0 & 0 & 0 & 0\end{array}$

51. Hoevaak had u een steeds terugkerende droom die de slaap verstoorde?

00

00

0

$\mathrm{Nu}$ volgen een aantal vragen over hoe $u$ in de 3 maanden voorafgaande aan uw hartinfarct wakker werd en opstond.

52. Bent $\mathrm{u}$ in de 3 maanden voorafgaande aan uw hartinfarct steeds later wakker geworden? ja ? neen

53. Voelde u zich beter uitgerust als u later dan gewoonlijk opstond? ja ? neen

54. Hoevaak werd u vroeger wakker dan u wenselijk vond? nooit zelden soms vaak altijd
0
0
$0 \quad 0$
0

55. Indien u te vroeg wakker werd, kon u dan weer gemakkelijk inslapen?

$\begin{array}{lllll}0 & 0 & 0 & 0 & 0\end{array}$


56. Hoevaak versliep u zich langer dan 1 uur?

0

0

$\begin{array}{lll}0 & 0 & 0\end{array}$

57. Hoevaak merkte u dat u erg moeilijk wakker kon worden?

$\begin{array}{lllll}0 & 0 & 0 & 0 & 0\end{array}$

58. Hoevaak voelde $u$ zich te moe om op te staan?

$\begin{array}{lllll}0 & 0 & 0 & 0 & 0\end{array}$

59. Hoevaak voelde u zich verward bij het wakker worden?

$\begin{array}{lllll}0 & 0 & 0 & 0 & 0\end{array}$

60. Hoevaak was u nog aan het dromen terwijl u wakker werd?

61. Hoevaak voelde u zich uitgerust als u wakker werd?

$\begin{array}{lllll}0 & 0 & 0 & 0 & 0\end{array}$

62. Hoevaak kon u zich onmogelijk bewegen bij het wakker worden?

$\begin{array}{lllll}0 & 0 & 0 & 0 & 0\end{array}$

63. Hoevaak werd u wakker met pijn in armen en benen?

$\begin{array}{lllll}0 & 0 & 0 & 0 & 0\end{array}$

64. Hoevalak werd u wakker net hoofdpijn?

$0 \quad 0 \quad 0 \quad 000$

65. Hoelang duurde het meestal voor $u$ 0 minder dan 5 min. 0 minder dan $20 \mathrm{~min}$. 0 minder dan $60 \mathrm{~min}$. 0 meer dan $60 \mathrm{~min}$.

66. Hoevaak heeft $\mathrm{t}$ in de 3 maanden voorafgaande aan uw infarct problemen 0 minder dari 1 keer per maand gehad met wakker worden en opstaan? 01 tot 4 keer per maand 02 tot 4 keer per week 0 bijna elke dag

Nu volgen een aantal vragen over hoe goed $u$ in de 3 maanden voorafgaande aan uw hartinfarct in staat was uw dagelijkse bezigheden uit te voeren:

67. Hoelang duurde het gewoonlijk voor u op gang kwam na het opstaan?
0 minder dan $30 \mathrm{~min}$.

0 minder dan $60 \mathrm{~min}$.

0 meer dan $60 \mathrm{~min}$. 
68. Hoevaak deed u overdag een dutje?

0 minder dan 1 keer per maand

01 tot 4 keer per maand

02 tot 4 keer per week

0 bijna elke dag

69. Hoe voelde u zich na een dutje in

0 beter vergelijking met voor een dutje?

0 hetzelfde

0 slechter

0 niet van toepassing

nooit zelden soms vaak altijd

70. Viel u overdag in slaap zonder dat u dat wilde?

$\begin{array}{lllll}0 & 0 & 0 & 0 & 0\end{array}$

71. Viel u altijd in slaap als u een dutje wilde gaan doen?

$\begin{array}{lllll}0 & 0 & 0 & 0 & 0\end{array}$

72. Hoevaak voelde u zich fris en energiek tijdens uw dagelijkse bezigheden?

$\begin{array}{lllll}0 & 0 & 0 & 5 & 0\end{array}$

73. Hoevaak had u tijdens uw dagelijkse bezigheden last van slaperigheid?

$\begin{array}{lllll}0 & 0 & 0 & 0 & 0\end{array}$

74. Hoevaak had $\mathrm{u}$ last van vermoeidheid tijdens uw dagelijkse bezigheden?

$\begin{array}{lllll}0 & 0 & 0 & 0 & 0\end{array}$

75. Hoevaak had u moeite om wakker te bijiven tijdens uw dagelijkse bezigheden?

$\begin{array}{lllll}0 & 0 & 0 & 0 & 0\end{array}$

76. Indien u zich overdag vermoeid voelde hoe uitte zich dit?
0 lichamelijk:
0 geestelijk
0 beide
0 niet van toepassing

heel

heel

goed goed matig slecht slecht

77. Hoe goed was u vroeger in staat uw dagelijkse bezigheden uit te voeren?

$\begin{array}{lllll}0 & 0 & 0 & 0 & 0\end{array}$

78. Hoe goed functioneerde $u$ in de 3 maanden voorafgaande aan uw infarct 's morgens?

$\begin{array}{lllll}0 . & 0 & 0 & 0 & 0\end{array}$


79. Hoe goed functioneerde $u$ in de 3 maanden vooragaande aan uw infarct 'middags?
0
$\begin{array}{llll}0 & 0 & 0 & 0\end{array}$

80. Hoe goed functioneerde $u$ in de 3 maanden voorafgaande aan uw infarct in de namiddag?
$0 \quad 0$
$0 \quad 0$
0

81. Hoe goed functioneerde $u$ in de 3 maanden voorafgaande aan uw infarct in het begin van de avond?

$\begin{array}{lllll}0 & 0 & 0 & 0 & 0\end{array}$

82. Hoe goed functioneerde $u$ in de 3 maanden voorafgaande aan uw infarct 's avonds?
$0 \quad 0$
0
$0 \quad 0$
0

Nu volgen enkele slotvragen:

83. Heeft u wel eens een aantal dagen achtereen geslapen?

ja ? neen

84. Slaapt u tijdens uw vrije dagen, weekend, of vakantie langer, korter of hetzelfde?

0 langer

0 korter

0 hetzelfde

85. Voelt u zich dan beter/s!echter/ hetzelfde?

0 beter
0 slechter
0 hetzelfde

86. Hoe slaapt u buitenshuis in vergelijking

0 beter met thuis?

0 slechter

0 hetzelfde

G niet van toepassing

87. Gebruikte u in de 3 maanden voorafnooit zelden soms vaak altijd gaande aan uw infarct medicijnen om te kunnen slapen?

$\begin{array}{lllll}0 & 0 & 0 & 0 & 0\end{array}$

88. Gebruikte $u_{i}$ in de 3 maanden voorafgaande aan uw infarct medicijnen tegen slaperigheid of vermoeidheid?

$\begin{array}{lllll}0 & 0 & 0 & 0 & 0\end{array}$


89. Gebruikte $u$ in de 3 maanden voorafgaande aan uw infarct koffie voor het slapen galan?

$\begin{array}{lllll}0 & 0 & 0 & 0 & 0\end{array}$

90. Gebruikte $\mathrm{u}$ in de afgelopen 3 maanden vocrafgaande aan uw infarct alcohol voor het slapen gaan?

$\begin{array}{lllll}0 & 0 & 0 & 0 & 0\end{array}$

91. Gebruikte $u$ in de 3 maanden voorafgaande aan uw infarct alcohol om in slaap te komen?

$\begin{array}{lllll}0 & 0 & 0 & 0 & 0\end{array}$

92. At u in de 3 maanden voorafgaande aan uw infarct voor het slapen gaan?

$\begin{array}{lllll}0 & 0 & 0 & 0 & 0\end{array}$

93a. Rookte $\mu$ in de 3 maanden voorafgaande aan $u w$ infarct voor het slapen gaan?

$\begin{array}{lllll}0 & 0 & 0 & 0 & 0\end{array}$

93b. Indien u rookte hoeveel sigaretten

0 1. 5 sigaretten per dag rookte u gemiddeld per dag in de 0 6-10 sigaretten per dag afgelopen 3 maanden voorafgaande aan uw infarct?

0 11-19 sigaretten per dag

0 20-39 sigaretten per dag 040 en meer

94. Indien u slaapproblemen had deden die zich dan periodiek voor?

ja ? neen

95. Kunt u tot slot aangeven wat $\underline{u}$ onder goede slaap verstaat? 


\section{BIJLAGE 3. VRAGENLLJST VOOR HET METEN VAN WERKLAST}

werkt U ?

ja nee

Welke van de volgende belastingsfactoren kenmerkt Uw werk ?

- Het werken in diensten, zonder nachtdienst

ja nee

- Het werken in diensten, met nachtdienst

ja nee

- Er is veel lawaai op het werk

- Tijdsdruk

- Storingen, onderbrekingen

- Tegenstrijdige eisen

- Overwerken

- Sterke controle, weinig speelruimte

- Gebrekkige ondersteuning door collega's

- Ontbreken van waardering door hogeren

ja nee

ja nee

ja nee

ja nee

ja nee

ja nee

ja nee

ja nee

Was er de laatste 12 maanden een toename te constateren in:

- tijdsdruk

- verantwoordelijkheid

- moeilijkheid

- onzekerheid over behoud van het werk

ja nee

ja nee

ja nee

ja nee 


\section{BIJLAGE 4.}

DE AANGEPASTE SLAAPKLACHTENLIJST VAN JENKINS

1. "Had $\mathrm{U}$ in de 3 maanden voorafgaande aan de ziekenhuisopname problemen met het inslapen" (helemaal niet; een beetje; nogal; erg; heel erg);

2. "Hoe vaak bent $U$ in de 3 maanden voorafgaande aan de ziekenhuisopname tijdens uw slaap volledig wakker geworden" (minder dan 1 keer per maand; 1 tot 4 keer per maand; 1 tot 4 keer per week; bijna elke nacht);

3. "Had $U$ in de 3 maanden voorafgaande aan de ziekenhuisopname problemen met te vroeg wakker worden" (helemaal niet; een beetje; nogal; erg; heel erg);

4. "Had $U$ in de 3 maanden voorafgaande aan de ziekenhuisopname last van vermoeidheid bij het opstaan ook al had U genoeg geslapen" (helemaal niet; een beetje; nogal; erg; heel erg). 


\section{BIJLAGE 5. \\ DE SLAAP-WAAK ERVARING LIJST (SWEL)}

\section{Problemen met:}

inslapen: $\quad$ "Is het voor U een probleem om in slaap te vallen"("nogal"; "erg"; "heel erg"); en

"Als U wilde gaan slapen, viel' U dan snel inslaap"("zelden" of nooit").

doorslapen: "Is het voor $\mathrm{U}$ een. probleem als $\mathrm{U}$ 's nachts. wakker wordt" ("nogal"; "erg"; "heel erg"), of

"Als U 's nachts wakker wordt, is het dan een probleem. weer in slaap te vallen" ("nogal"; "erg"; "heel erg"), en

"Kon $U$ meestal weer snel inslapen als $U$ uit uw slaap wakker was geworden" ("zelden"; "nooit").

te vroeg "Heeft U problemen met 's ochtends te vroeg wakker worden" ("nog wakker al"; "erg"; "heel erg") en

worden: "Hoevaak werd U vroeger wakker dan U wenselijk vond" ("vaak"; "altijd") en

"Indien U te vroeg wakker werd, kon U' dan weer gemakkelijk inslapen" ("zelden"; "nooit").

moe wakker

worden:

"Heeft U last van vermoeidheid bij het opstaan, ook al heeft U voldoende geslapen" ("nogal"; "erg"; "heel erg") en

"Hoevaak voelde U zich te moe om op te staan." ("vaak"; "altijd").

moeilijk

wakker

"Heeft U problemen met 's morgens moeilijk wakker worden en op

en opstaan: staan"

("nogal": "erg",: "heel erg") en "Hoevaak merkte U dat U erg moeilijk wakker kon worden" ("vaak"; "altij.d").

slaperigheid "Viel U overdag, regelmatig in slaap zonder dat $U$ dat wilde ?" overdag, ("vaak", "altijd)

of "Hoevaak had $U$ tijdens uw dagelijkse bezigheden moeite om wakker te blijven?" ("vaak"; "altijd") of "hoevaak had U tijdens Uw dagelijkse bezigheden moeite om wakker te blijven ?" ("vaak", "altijd)

vermoeidheid overdag:

"Heeft U last van vermoeidheid overdag, zonder U slaperig te voelen" ("nogal";

"erg"; "heel erg") en "Hoevaak had $\mathbf{U}$ tijdens uw dagelijkse bezigheden last van vermoeidheid" ("vaak"; "altijd"). 


\section{BIJLAGE 6. \\ VRAGEN M.B.T. INSOMNIA}

1. "Had $\mathrm{U}$ in de drie maanden voorafgaande aan uw ziekenhuisopname problemen met in slaap komen?" ("helemaal niet", "een beetje", "nogal", "erg", "heel erg").

2. "Voelde $U$ het als een probleem als $u$ in de drie maanden voorafgaande aan uw infarct 's nachts wakker werd? "("helemaal niet", "een beetje", "nogal", "erg", "heel erg").

3. "Als u 's nachts wakker werd in de afgelopen 3 maanden voorafgaande aan het hartinfarct, had u dan problemen om weer in slaap te komen?" ("helemaal niet", "een beetje", "nogal", "erg", "heel erg").

4. "Had $U$ in de 3 maanden voorafgaande aan uw infarct problemen met te vroeg wakker worden?" ("helemaal niet", "een beetje", "nogal", "erg", "heel erg").

5. "Viel u meestal op een vaste tijd in slaap?" ("ja", "?", "nee").

6. "Zijn er de afgelopen tijd periodes geweest dat U steeds later kon in slapen?" ("ja", "?", "nee").

7. "Hoe lang duurde het meestal voordat $U$ in slaap viel?" ("minder dan 5 minuten", "minder dan 20 minuten", "minder dan 60 minuten", "langer dan 60 minuten").

8. "Hoe vaak lag U langer dan gewoonlijk wakker?" ("minder dan 1 keer per maand", "1 tot 4 keer per maand", "meer dan 1 keer per week").

9. "Als U wilde gaan slapen, viel U dan snel in slaap?" ("nooit", "zelden", "soms", "vaak", "altijd").

10. "Was u in de 3 maanden voorafgaande aan uw hartinfarct regelmatig langer dan 5 minuten uit bed?" ("ja", "?", "nee").

11. "Hoe vaak werd u wakker tijdens uw slaapperiode?" ("nooit", "1 tot 3 keer", "4. tot 6 keer", "meer dan 6 keer")

12. "Indien u wakker werd, hoelang bleef U dan meestal wakker?" ("minder dan 5 minuten", "minder dan 20 minuten", "minder dan 60 minuten", "langer dan 60 minuten").

13. "Indien u wakker werd, hoevaak stond u dan meestal op?" ("nooit", "1 tot 3 keer", "4 tot 6 keer", "meer dan 6 keer").

14. "Hoe vaak bent $U$ in de 3 maanden voorafgaande aan uw infarct tijdens uw slaap volledig wakker geworden?" ("minder dan 1 keer per maand", "1 tot 4 keer per maand", "I tot 4 keer per week", "bijna elke nacht").

15. "Kon U weer snel inslapen nadat u wakker was geworden?" ("nooit", "zelden", "soms", "vaak", "altijd").

16. "Hoe vaak werd u vroeger wakker dan u wenselijk vond?" ("nooit", "zelden", "soms", "vaak", "altijd").

17. "Indien u te vroeg wakker werd, kon U dan weer gemakkelijk inslapen?" ("nooit", "zelden", "soms", "vaak", "altijd"). 


\section{BIJLAGE 7. \\ VRAGEN M.B.T. HYPERSOMNIA}

1. "Had u last van vermoeidheid overdag in de 3 maanden voorafgaande aan uw infarct, zonder u slaperig te voelen?" ("helemaal niet", "cen beetje", "nogal", "erg", "heel erg").

2. "Hoe vaak deed u overdag een dutje?" ("minder dan I keer per maand", "1 tot 4 keer per maand", "2 tot 4 keer per week", "bijna elke dag").

3. "Viel U overdag in slaap zonder dat u dat wilde?" ("nooit","zelden", "soms", "vaak","altijd").

4. "Viel u altijd in slaap als u een dutje wilde gaan doen?" ("nooit", "zelden", "soms", "vaak", "altijd").

5. "Hoe vaak voelde u zich fris en energiek tijdens uw dagelijkse bezigheden?" ("nooit", "zelden", "soms", "vaak", "altijd").

6. "Hoe vaak had U tijdens uw dagelijkse bezigheden last van slaperigheid?" ("nooit", "zelden", "soms", "vaak", "altijd").

7. "Hoe vaak had $U$ last van vermoeidheid tijdens uw dagelijkse bezigheden?" ("nooit", "zelden", "soms", "vaak", "altijd").

8. "Hoe vaak had $\mathrm{U}$ moeite om wakker te blijven tijdens uw dagelijkse bezigheden?" ("nooit", "zelden", "soms", "vaak", "altijd"). 


\section{BIJLAGE 8.}

\section{VRAGEN M.B.T. SLAAPAPNEU}

1. "Voelde $U$ het als een probleem als $u$ in de drie maanden voorafgaande aan uw infarct 's nachts wakker werd?" ("helemaal niet", "een beetje", "nogal", "erg", "heell erg").

2. "Als û 's nachts wakker werd in de afgelopen 3 maanden voorafgaande aan het hartinfarct, had ti dan problemen om weer in slaap te komen?" ("helemaal niet", "een beetje", "nogal", "erg", "heel erg").

3. "Had $U$ in de 3 maanden voorafgaande aan uw infarct problemen met te vroeg wakker worden?" ("helemaal niet", "een beetje", "nogal", "erg", "heel erg").

4. "Had U last van vermoeidheid overdag in de 3 maanden voorafgaande aan uw infarcı, zonder u slaperig te voelen?" ("helemaal niet", "een beetje", "noga!", "erg", "heel erg").

5. "Weet u via uw partner of anderen dat u snurkt tijdens uw slaap?" ("ja", "?", "nee").

6. "Weet u via uw partner of anderen dat u overmatig met uw benen beweegt tijdens uw slaap?" ("ja", "?", "nee").

7. "Weet $U$ via uw partner of anderen dat u onregelmatig ademt tijdens uw slaap?" ("ja", "?", "nee").

8. "Was $\mathrm{u}$ in de 3 maanden voorafgaande aan uw hartinfarct regelmatig langer dan 5 minuten uit bed?" ("ja", "?", "nee").

9. "Hoe vaak werd u meestal wakker tijdens uw slaapperiode?" ("nooit", "I tot 3 keer", "4 tot 6 keer", "meer dan 6 keer").

10. "Indien $U$ wakker werd hoe vaak stond u dan meestal op?"' ("minder dan 5 minuten", "minder dan 20 minuten", "minder dan 60 minuten", "langer dan 60 minuten").

11. "Hoe vaak bent $u$ in de 3 maanden voorafgaande aan uw infarct tijdens uw slaap volledig wakker geworden?" ("minder dan ! keer per maand", "! tot 4 keer per maand", "I tot 4 keer per week", "bijna elke nacht").

12. "Kon u weer snel inslapen nadat u wakker was geworden?" ("nooit", "zelden", "soms", "vaak", "altijd").

13. "Hoe vaak had u het benauwd als u uit uw slaap wakker werd?" ("nooit", "zelden", "soms.", "vaak", "altijd").

14. "Hoe vaak werd u vroeger wakker dan u wenselijk vond?" ("nooit.", "zelden", "soms", "vaak", "altijd").

15. "Indien U te vroeg wakker werd, kon U dan weer gemakkelijk inslapen?" ("nooit", "zelden", "soms", "vaak", "altijd").

16. "Hoe vaak voelde u zich verward bij het wakker worden?" ("nooit", "zelden", "soms", "vaak", "altijd").

17. "Hoe vaak werd u wakker met hoofdpijn?" ("nooit", "zelden", "soms", "vaak", "altijd"). 
18. "Hoe vaak deed u overdag een dutje?" ("minder dan 1 keer per maand", "1 tot 4 keer per maand", "1 tot 4 keer per week", "bijna elke dag").

19. "Viel u overdag in slaap zonder dat u dat wilde?" ("nooit", "zelden", "soms", "vaak", "altijd").

20. "Viel u altijd in slaap als u een dutje wilde gaan doen?" ("nooit", "zelden", "soms", "vaak", "altijd").

21. "Hoe vaak voelde u zich fris en energiek tijdens uw dagelijkse bezigheden?" ("nooit", "zelden", "soms", "vaak", "altijd").

22. "Hoe vaak had $U$ tijdens uw dagelijkse bezigheden last van slaperigheid?" ("nooit", "zelden", "soms", "vaak", "altijd").

23. "Hoe vaak had u last van vermoeidheid tijdens uw dagelijkse bezigheden?" ("nooit", "zelden", "soms", "vaak", "altijd").

24. "Hoe vaak had u moeite om wakker te blijven tijdens uw dagelijkse bezigheden?" ("nooit", "zelden", "soms", "vaak", "altijd"). 


\section{BIJLAGE 9. \\ VRAGEN M.B.T. LICHAMELIJKE EN \\ GEESTELIJKE OORZAKELIJKE FACTOREN}

\section{A. Lichamelijke factoren:}

1. "Hoe vaak kon U voor het inslapen uw benen onmogelijk stilhouden?" ("nooit", "zelden",soms", "vaak", "altijd").

2. "Hoe vaak had u last van pijn of lichamelijk ongemak?" ("nooit", "zelden", "soms", "vaak", "altijd").

3. "Hoe vaak had u bij het inslapen het gevoel dat u zich niet meer kon bewegen?" ("nooit", "zelden", "soms", "vaak", "altijd").

4. "Hoe vaak werd u wakker met pijn of prikkeling in de benen?" ("nooit", "zelden", "soms", "vaak", "altijd").

5. "Hoe vakk werd u benauwd wakker uit uw slaap?" ("nooit", "zelden", "soms", "vaak", "altijd").

6. "Hoe vaak werd u wakker met pijn in armen en benen?" ("nooit", "zelden", "soms", "vaak", "altijd").

7. "Hoe vaak werd u wakker met hoofdpijn?" ("nooit", "zelden", "soms", "vaak", "altijd").

B. Geestelijke factoren:

1. "Hoe vaak makkte U zich zorgen voor het inslapen?" ("nooit", "zelden", "soms", "vaak.", "altijd").

2. "Hoe vaak had $\mathrm{U}$ voor het inslapen last van een verdrietig of somber gevoel?" ("nooit", "zelden", "soms", "vaak", "altijd").

3. "Hoe vaak voelde U zich angstig voor het inslapen?" ("nooit", "zelden", "soms", "vaak", "altijd").

4. "Hoevaak was $U$ bang niet inslaap te kunnen vallen?" ("nooit", "zelden", "soms", "vaak", "altijd").

5. "Hoe vaak had u last van nachtmerries?" ("nooit", "zelden", "soms", "vaak", "altijd").

6. "Hoe vaak werd u wakker uit een droom?" ("nooit", "zelden", "soms", "vaak", "altijd").

7. "Hoe vaak had u een steeds terugkerende droom die de slaap verstoorde?" ("nooit", "zelden", "soms", "vaak", "altijd").

8. "Hoe vaak voelde u zich verward bij het wakker worden? ("nooit", "zelden", "soms", "vaak", "altijd"). 


\section{BIJLAGE 10. \\ DE VRAGENLIJST MET 24 ITEMS WAARMEE VITALE UITPUTTING WORDT GEMETEN}

01: "Voelde U zich in de afgelopen twee tot drie maanden vaak moe?"

02: "Had U er vaak moeite mee in te slapen?"

03: "Werd U 's nachts vaak wakker?"

04: "Ik kon de laatste tijd erg opvliegend zijn"

05: "Voelde U zich vaak slap?"

06: "Had U het gevoel dat U de laatste tijd weinig presteerde?"

07: "Had $\mathrm{U}$ in de afgelopen twee tot drie maanden wel eens het gevoel dat het allemaal wat te veel werd?"

08: "Kon U de laatste tijd door kleine dingen erg geprikkeld raken?"

09: "Voelde U zich de laatste tijd lustelozer dan vroeger?"

10: "Had U weleens het gevoel dat U uzelf steeds minder in uw macht had?"

11: "Ik had net zoveel plezier in het sexuele als vroeger?"

12: "Deed U er langer over om een moeilijk probleem te begrijpen dan een jaar geleden?"

13: "Was het zo dat allerlei kleine dingen $U$ meer ergerden dan vroeger?"

14: "Hebt $U$ de laatste tijd weleens het verlangen voelen opkomen het bijltje erbij neer te leggen?"

15: "Was U minder tevreden over U zelf?"

16: "Ik voelde mij de laatste maanden prima"

17: "Voelde U zich gedeprimeerd of teneergeslagen?"

18: "Had U weleens het gevoel dat Uw lichaam een batterij was, waarvan de kracht of het vermogen aan het opraken was ?"

19: "Voelde U zich minder in staat iets nuttigs te doen?"

20: "Wilde U soms wel eens dood zijn?"

21: "Had U het gevoel dat U niet meer zoveel waard was als yroeger?"

22: "Voelde U zich moedeloos?"

23: "Schudde en beefde U weleens over Uw gehele lichaam?"

24: "Werd U weleens wakker met een gevoel van uitputting en vermoeidheid?" 


\section{BIJLAGE 11. DE MARBURGSE LIJST}

code:

Werkte $\mathrm{u}$ in de afgelopen drie maanden?

0 ja 0 nee

Indien $\mathrm{u}$ niet meer werkt, hoelang werkt u dan niet meer?

Leeftijd:

Wilt u deze 51 vragen spontaan beantwoorden met ja! (uitgesproken ja), ja, nee, nee! (uitgesproken nee). Kruist u a.u.b. het juiste antwoord aan. Zoudt u aan willen geven welk antwoord het meest op $\mathrm{u}$ van toepassing is. Iedere persoon heef andere gewoonten, zodat er geen goede of foute antwoorden zijn.

Het gaat om uw persoonlijke mening.

De vragen hebben betrekking op de afgelopen drie manden. Indien u tijdens deze periode niet werkte wilt u dan de vragen toch beantwoorden en wilt $U$ dan uitgaan van de periode waarin u wel nog werkte.

\section{Voorbeeld:}

Vindt $u$ het vervelend als iemand $u$ laat wachten?

Wanneer $u$ het uitgesproken vervelend vindt

vult u het hokje ja! in, dus zo:

0 ja! 0 ja 0 nee 0 nee!

Vindt $u$ het vervelend dan vult $u$ het hokje

ja in, dus zo:

0 ja! 0 ja 0 nee 0 nee!

Vindt $u$ het niet vervelend dan vult $u$ het

hokje nee in, dus zo:

0 ja! 0 ja 0 nee 0 nee!

Vindt $u$ het helemaal niet vervelend dan

vult u het hokje nee! in, dus zo:

0 ja! 0 ja 0 nee 0 nee!

Wilt u alle vragen beantwoorden en bij elke vraag slechts één hokje aankruisen

1. Ik was meestal erg gevoelig yoor kritiek

2. Ik was eerzuchtig

3. Ongeacht wat ik ook deed, ik. zette me altijd voor de volle $100 \%$ in

4. Ik hield van netheid en ruimde altijd alles; op

5. De kleinste onderbreking vond ik erg hinderlijk:

6. Wanneer een opdracht goed uitgevoerd moest worden dan bemoeide ik me er het liefste zelf mee
0 ja! 0 ja 0 nee 0 nee!

0 ja! 0 ja 0 nee 0 nee!

0 ja! 0 ja 0 nee 0 nee!

0 ja! 0 ja 0 nee 0 nee!

0 ja! 0 ja 0 nee 0 nee!

0 ja! 0 ja 0 nee 0 nee! 
7. Ik voelde me soms erg ongelukkig

8. Ik kon werk onafgemaakt zonder problemen laten liggen

9. Het deed mij bij bepaalde mensen plezier hen op hun fouten te wijzen

10. Als veel werk samenkwam ging ik extra hard werken

11. Voor ik ergens mee begon maakte ik allereerste een planning

12. Ik vond het plezierig altijd beter of sneller te zijn dan anderen

13. Wanneer iemand mij belemmerde in het vervullen van mijn plichten dan kon ik mij opwinden

14. Ik voelde me soms leeg

15. Ik had er geen problemen mee langer te pauzeren dan gebruikelijk was

16. Vaak maakte ik me druk over anderen, meer dan terecht zou zijn

17. Ik voelde me goed wanneer ik weinig te doen had

18. Om tot een succesrijke prestatie te komen moest er orde heersen

19. I k kwam snel in tijdnood

20. Het gebeurde al dat ik al bij het wakker worden aan problemen op het werk dacht

21. Vaak had ik er enorm genoeg van

22. Het ergerde me als ik mijn werk niet voor de volle $100 \%$ kon uitvoeren

23. Aan mijn werk mocht niemand komen

24. Ik was veor mezelf harder dan voor andere mensen

25. Ik was teleurgesteld wanneer mijn prestaties niet erkend werden

26. Wanneer anderen iets niet snel konden begrijpen dan kon ik me enorm opwinden

27. Ik werkte geconcentreerder dan anderen

28. Ik droomde vaak over dingen die toch nooit werkelijkheid konden worden

29. Als ik thuis kwam kon ik het werk zonder problemen van me afzetten

30. Mijn vrouw vond dat ik me opofferde voor mijn werk

31. Ik had alleen dan succes wanneer mijn prestaties mijn verwachtingen overtroffen

32. Als ik een opdracht beëindigd had, begon ik gemakkelijk aan de volgende
0 ja! 0 ja 0 nee 0 nee!

0 ja! 0 ja 0 nee 0 nee!

0 ja! 0 ja 0 nee 0 nee!

0 ja! 0 ja 0 nee 0 nee!

0 ja! 0 ja 0 nee 0 nee!

0 ja! 0 ja 0 nee 0 nee?

0 ja! 0 ja 0 nee 0 nee!

0 ja! 0 ja 0 nee 0 nee!

0 ja! 0 ja 0 nee 0 nee!

0 ja! 0 ja 0 nee 0 nee!

0 ja! 0 ja 0 nee 0 nee!

0 ja! 0 ja 0 nee 0 nee!

0 ja! 0 ja 0 nee 0 nee!

0 ja! 0 ja 0 nee 0 nee!

0 ja! 0 ja 0 nee 0 nee!

0 ja! 0 ja 0 nee 0 nee!

0 ja! 0 ja 0 nee 0 nee!

0 ja! 0 ja 0 nee 0 nee!

0 ja! 0 ja 0 nee 0 nee!

0 ja! 0 ja 0 nee 0 nee!

0 ja! 0 ja 0 nee 0 nee!

0 ja! 0 ja 0 nee 0 nee!

0 ja! 0 ja 0 nee 0 nee!

0 ja! 0 ja 0 nee 0 nee!

0 ja! 0 ja 0 nee 0 nee!

0 ja! 0 ja 0 nee 0 nee! 
33. Collega's zeiden bij moeilijke problemen van mij: hij komt daar wel uit

34. Ook onder tijdsdruk werkte ik altijd nauwkeurig

35. Ik wilde alles zoveel mogelijk onder controle houden

36. Mijn stemming wisselde nogal vaak

37. Collega's die erg nauwkeurig waren werkten me op mijn zenuwen

38. Het gezin kwam op de eerste plaats, dan het werk

39. Als een collega tijdens het samenwerken aan mijn vaardigheden twijfelde kon ik kwaad worden

40. Ik stelde in principe hogere eisen aan mezelf dan aan anderen

41. Ik ging zolang door met het werk tot het klaar was ongeacht hoelang het duurde

42. Het stoorde me helemaal niet als ik mijn werkzaamheden onderbreken moest

43. Ik piekerde vaak

44. Ik nam iedere keer weer meer voor, meer dan dat ik in daden kon omzetten

45. Het werk liet me zelden los

46. Ook het kleinste pluimpje spoorde me ontzeltend aan

47. Ik vond het niet vervelend als anderen mij overtroffen

48. Ik liet me erg graag eens een keer van het werk afhouden

49. In gedachten was ik altijd weer bij de volgende opdracht

50. Ik had vaak afdwalende gedachten

51. Als ik iets uitstelde wat ik eigenlijk zou moeten doen dan kon ik er 's nachts niet van slapen

0 ja! 0 ja 0 nee 0 nee!

0 ja! 0 ja 0 nee 0 nee!

0 ja! 0 ja 0 nee 0 nee!

0 ja! 0 ja 0 nee 0 nee!

0 ja! 0 ja 0 nee 0 nee!

0 ja! 0 ja 0 nee 0 nee!

0 ja! 0 ja 0 nee 0 nee!

0 ja! 0 ja 0 nee 0 nee!

0 ja! 0 ja 0 nee 0 nee!

0 ja! 0 ja 0 nee 0 nee!

0 ja! 0 ja 0 nee: 0 nee!

0 ja! 0 ja 0 nee 0 nee!

0 ja! 0 ja 0 nee 0 nee!

0 ja! 0 ja 0 nee 0 nee!

0 ja! 0 ja 0 nee 0 nee!

0 ja! 0 ja 0 nee 0 nee!

0 ja! 0 ja 0 nee 0 nee!

0 ja! 0 ja 0 nee 0 nee!

0 ja! 0 ja 0 nee 0 nee! 


\section{BIJLAGE 12. \\ DE ROSE QUESTIONNAIRE}

De volgende vragen gaan over borstklachten die sommige mensen wel en andere mensen niet gehad hebben. De vragen gaan over een periode van ongeveer een half jaar, voor ziekenhuisopname. Het gaat om pijn en onplezierige gevoelens in de borst die niet werden veroorzaakt door een verkoudheid, maar die eventueel van het hart afkomstig kunnen zijn geweest.

1. "Had U weleens pijn of een onaangenaam gevoel in de borst (verkoudheid niet meetellen)?" ('ja", "?", "nee")

2. "Had $\mathrm{U}$ weleens een drukkend of zwaar gevoel op de borst (verkoudheid niet meetellen?" ("ja", "?", "nee")

3. "Had U weleens aanvallen van beklemmende pijn in de borst?" ("ja", "?", "nee")

Als $U$ alle drie bovenstaande vragen met "nee" heeft beantwoord, kunt $U$ de volgende vragen overslaan en doorgaan met vraag 15.

4. "Kreeg U deze druk of pijn als $U$ een helling of trap opliep, als $U$ zich voorthaastte, of als U tegen de wind in liep of fietste?" ("ja" "?", "nee")

5. "Kreeg U deze druk of pijn als U gewoon op straat liep?" ("ja", "?", "nee")

Als $U$ de vragen 4 en 5 met "nee" heeft beantwoord, kunt $U$ doorgaan met vraag 8.

6. "Wat deed U als U deze druk of pijn kreeg terwijl U liep of fietste? " ("gewoon doorlopen of doorfietsen", "langzamer lopen of fietsten, of stilstaan", "tablet onder de tong nemen")

7. "De druk of pijn verdween dan .... ("binnen tien minuten", "na langer dan tien minuten", "helemaal niet")

8. "Kreeg U deze druk of pijn...... ("als U van warmte in de kou kwam", "als U van de kou in de warmte kwam", "als U opgewonden of overstuur was", "binnen tien minuten na de maaltijd")

9. "Zijn de klachten van pijn of drukkend gevoel in de borst pas de laatste drie maanden opgetreden?" ("ja", "?", "nee")

10. "Kwamen de klachten van pijn of drukkend gevoel in de borst pas de laatste drie maanden veel vaker voor? ("ja", "?", "nee")

11. "Werden deze klachten steeds erger?" ("ja", "?", "nee")

12. "Had U ooit een aanval van ernstige pijn voor op de borst, die een half uur of langer duurde?" ("ja", "?", "nee")

Als U vraag 12 met "nee" heeft beantwoord, kunt $\mathrm{U}$ doorgaan met vraag 15.

13. "Heeft U meer dan eens zo'n langdurige pijn gehad? ("ja", "?", "nee")

14. "Hoe lang geleden had U de laatste aanval van pijn?" ("Korter dan 1 jaar geleden", "langer dan 1 jaar geleden")

15. "Heeft U ooit, (eerder) een hartinfarct gehad? ("ja", "?", "nee")

Zo ja, in welk jaar... 


\section{BIJLAGE 13. "LIFE EVENTS"}

a. Hebben, in de afgelopen maanden, de volgende gebeurtenissen plaats gevonden? (onderstreep de gebeurtenis)

b. Kunt $\mathrm{U}$ ook aangeven hoe aangrijpend die gebeurtenis voor $\mathrm{U}$ was? ("helemaal niet", "een beetje", "nogal", "erg", "heel erg")

1. Financiele problemen.

2. Opvoedkundige problemen.

3. Kinderen die het huis verlaten hebben.

4. Huwelijksproblemen.

5. Scheiding.

6. Ernstige ziekte/dood van een familielid.

7. Conflicten met familie/kennissen.

8. Ernstige ziekte/dood van kennissen/vrienden.

9. Problemen met collega's.

10. Problemen met ondergeschikten over werkzaamheden.

11. Problemen met chef over werkzaamheden.

12. Overwerken, extra uren na de normale werktijd gedurende langere tijd.

13. Toename in verantwoordelijkheid op het werk.

14. Promotie op het werk.

15. Uit noodzaak naar ander werk uitkijken.

16. Vrijwillig naar ander werk uitkijken.

17. In de WAO of ziektewet terecht zijn gekomen.

18. Werkeloos geworden. 


\section{BIJLAGE 14. LEEFGEWOONTEN}

1. "Gebruikte U slaapmiddelen in de 3 maanden voorafgaande aan de ziekenhuisopname?"

2. a. "Rookte U in de drie maanden voorafgaande aan de ziekenhuisopname?";

b. "Hoeveel en wat werd er gerookt?" ("Alleen pijp of sigaar", "1-9 sigaretten per dag", "10 of meer sigaretten per dag").

3. "Was $U$ in de periode voorafgaande aan ziekenhuisopname gestopt met roken?" ("meer dan 10 jaar geleden gestopt, "minder dan 10 jaar geleden gestopt")

4. "Dronk U koffie in het jaar voorafgaande aan de ziekenhuisopname?". ("1-5 koppen per dag", "6-10 koppen per dag", "11 of meer koppen per dag").

5. "Dronk U alcohol in het jaar voorafgaande aan de ziekenhuisopname?". 
.4. MOM. IIII

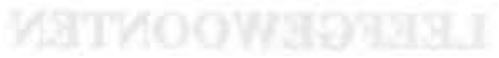




\section{DANKWOORD}

In de eerste plaats wil ik de mannen, die deelnamen aan het onderzoek mijn erkentelijkheid betuigen. Ondanks het feit dat aan hen, tijdens hun ziekenhuisopname, al vele vragen werden gesteld en zij aan vele onderzoeken moesten meewerken, waren zij toch bereid mee te werken aan het case-control onderzoek. Ook hun partners ben ik dank verschuldigd voor hun openhartigheid. De verpleegkundigen en afdelingshoofden van de betreffende afdelingen wil ik danken voor hun medewerking.

Het is hier op zijn plaats Jos Bekkers te bedanken. Jos bedankt, dat je iedere week weer opnieuw in de ziekenhuizen te Kerkrade en Roermond de patienten voor mij wilde benaderen. Ik weet dat dit werk veel meer tijd van je vroeg dan je verwachtte.

Prof. dr. A. Appels bedank ik voor de deskundige begeleiding en voor het vele geduld dat hij met mij had. Ik weet dat dit laatste meermalen op de proef werd gesteld. Ad, ik ben je zeer erkentelijk voor het vertrouwen dat je in mij hebt gesteld.

De samenwerking met mijn co-promotr dr. P. Falger heb ik als bijzonder plezierig en leerzaam ervaren. De deur van zijn kamer stond altijd voor mij open. Paul, bedankt voor alles wat je voor mij gedaan hebt in deze toch wel hectische tijd.

Het eerste bezoek aan dr. R. van Diest zal ik niet snel vergeten. Dit was het begin van het onderzoek. In eerste instantie door mee te werken aan de SWEL en tenslotte de voorbereiding en uitvoering van het case-control onderzoek. Rob, ik dank je voor de leerzame gesprekken, je energieke en aanstekelijke werklust, je steun en je hulp.

In het bijzonder wil ik Erik Schouten bedanken. Erik, je stond altijd voor mij klaar, beantwoordde geduldig mijn vragen en verdiepte je iedere keer weer opnieuw in het onderzoek. Mijn dank voor je inzet en onvermoeidbaar geduld.

Isel van Noppen heeft op accurate wijze de lay-out van dit proefschrift verzorgd. Isel, bedankt voor je steun en je hulp die je gaf bij allerhande problemen, waarmee ik je regelmatig lastig kwam vallen.

Dank ook aan Margriet van Woerden, Anny Le Doux en Joyce Angenent. Ook op jullie kon ik altijd een beroep doen.

Een woord van dank past ook de leden van de beoordelingscommissie, bestaande uit Prof. dr. F. Sturmans, Dr. F. Bär, Prof. dr. J. Jolles, Prof. dr. S. Maes en Dr. H. Merckelbach voor hun positief oordeel.

Tenslotte wil ik Lou danken voor het vele geduld dat hij met me heeft gehad. Lou, Luc en Mylou het wordt nu rustiger, dat beloof ik! 


\section{CURRICULUM VITAE}

De auteur van dit proefschrift is 26 december 1960 te Maastricht geboren. In 1979 behaalde zij het eindexamen Atheneum-B. Van 1979 tot 1985 studeerde zij psychologie aan de Katholieke Universiteit Brabant te Tilburg (hoofdrichting Klinische Psychologie).

Van juni 1985 tot juni 1990 was zij verbonden aan de vakgroep Medische Psychologie van de Rijksuniversiteit Limburg.

Van oktober 1985 tot heden is de auteur als docente werkzaam bij de opleiding Fysiotherapie, Hogeschool Heerlen en van oktober 1989 tot heden eveneens als docente bij de opleiding Verpleegkunde, Academisch Ziekenhuis te Maastricht.

Het onderzoek, waarover in dit proefschrift verslag wordt gedaan, werd uitgevoerd binnen divisie VIII "Psychosociale factoren van hart- en vaatziekten" (leider: Prof. dr. A.P.W.M. Appels). 

